Thesis Advisor: Elizabeth Herndon

Rapidly changing climate in high-latitude regions is altering biogeochemical cycles and potentially shifting arctic and sub-arctic ecosystems from sinks to sources of atmospheric carbon. Phosphorus (P) is an important nutrient whose availability may limit biological productivity and carbon storage in northern ecosystems. Here, we investigated the potential for phosphate adsorption to poorlycrystalline iron $(\mathrm{Fe})$ oxide minerals that precipitate during drainage of anoxic, Fe-rich peat soils to limit P bioavailability in high-latitude wetlands. We compared Fe and P geochemistry in organicrich soils collected from relatively depressed and saturated microtopographic positions to elevated and dry positions along a latitudinal gradient in northern North America, including tundra (Barrow Environmental Observatory, AK; Toolik Lake Field Station, AK) and boreal (Bonanza Creek Environmental Forest, AK; Marcell Experimental Forest, MN) ecosystems. We considered differences in soil saturation between microtopographic positions to be proxies for hydrologic changes driven by altered climate and the potential for permafrost degradation. To assess $\mathrm{P}$ sorption to Fe-oxides, we used phosphate sorption indices to evaluate the capacity for soils to bind phosphate and sequential extractions to quantify Fe phases, including exchangeable iron, organicbound iron, poorly-crystalline and crystalline iron oxides, and magnetite. Our results indicate that not only does iron speciation differ amongst the four study sites, but phosphate sorption capacity differs across microtopographic gradients in patterns that may reflect the accumulation of poorly 
crystalline Fe-oxides at oxic-anoxic interfaces, $\mathrm{pH}$, and/or influence of organic content. There was a direct correlation between poorly-crystalline iron oxides and the potential of the soil to sorb phosphate. Consequently, projected temperature increases in arctic and boreal regions may influence $\mathrm{P}$ availability due to increased association with poorly-crystalline Fe-oxides that precipitate as water tables lower in drying peatlands, wetlands, and polygonal landscapes. 


\title{
IRON REDOX CYCLING AND IMPACTS ON PHOSPHORUS SOLUBILITY IN TUNDRA
}

\section{AND BOREAL ECOSYSTEMS}

\author{
A thesis submitted \\ To Kent State University in partial \\ Fulfillment of the requirements from the \\ Degree of Master of Sciences
}

By

Kiersten Ann Duroe

December 2019

(C) Copyright

All rights reserved

Except for previously published materials 


\author{
Thesis written by \\ Kiersten Ann Duroe \\ B.S., State University of New York at Cortland, 2015 \\ M.S., Kent State University
}

Approved by

, Advisor

Dr. Elizabeth Herndon

, Chair, Department of Geology

Dr. Daniel Holm

, Dean, College of Arts and Sciences

Dr. James L. Blank 


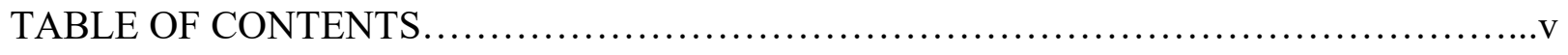

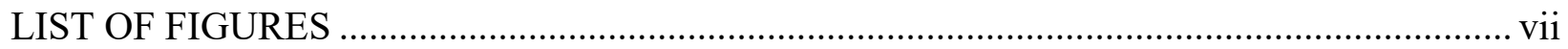

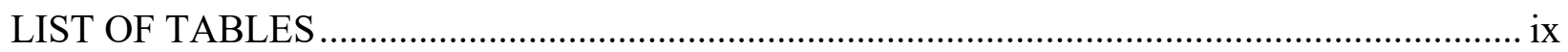

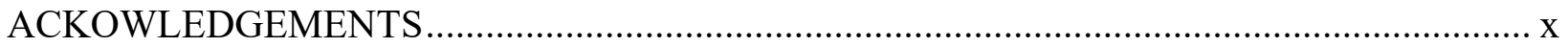

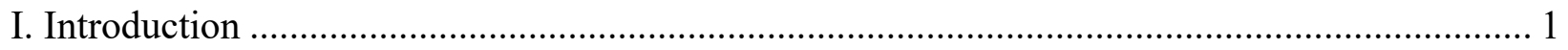

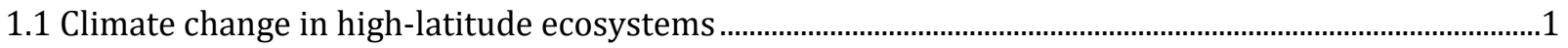

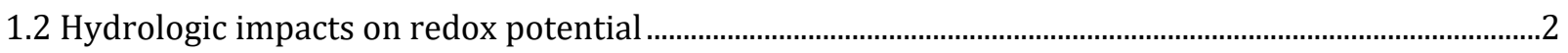

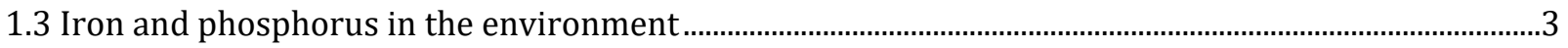

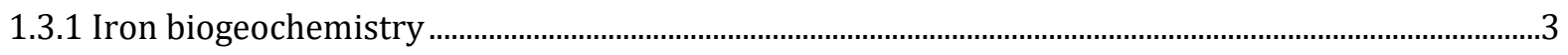

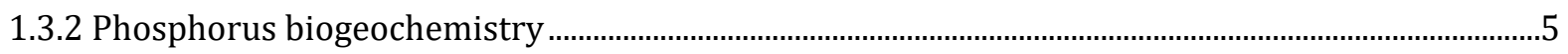

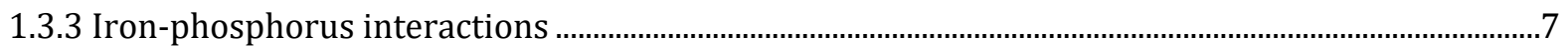

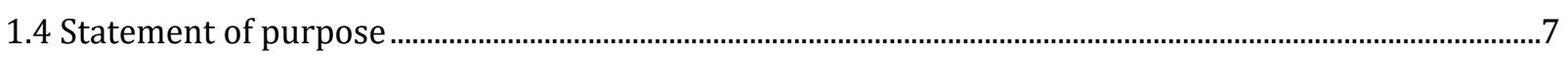

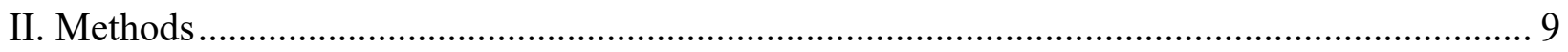

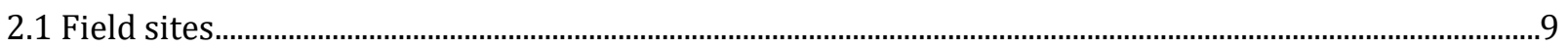

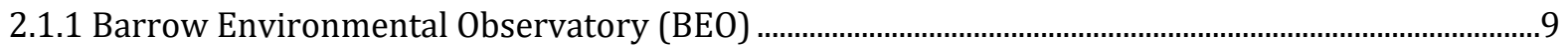

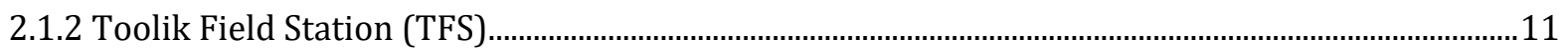

2.1.3 Alaskan Peatland Experiment (APEX) ………..................................................................................11

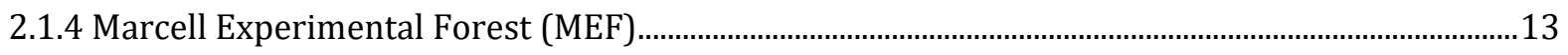

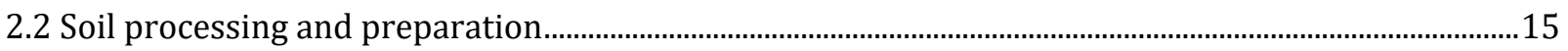

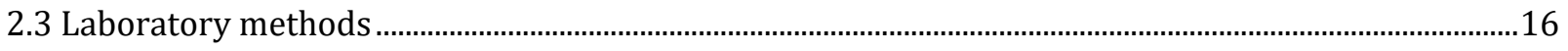

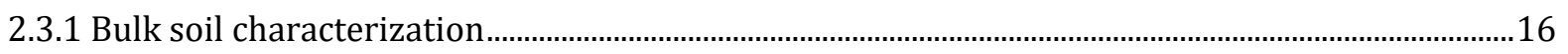

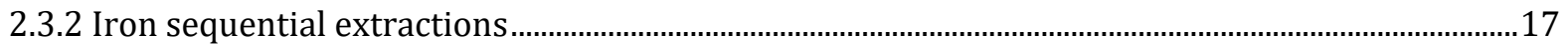


2.3.3 Phosphate sorption experiments

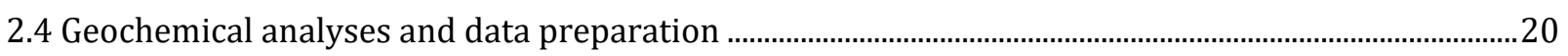

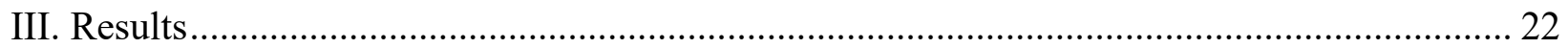

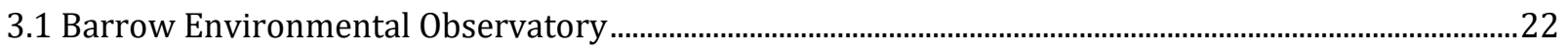

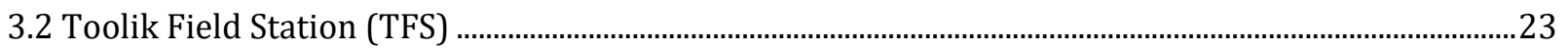

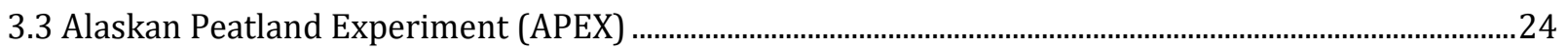

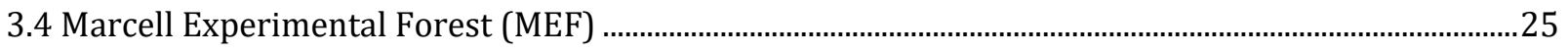

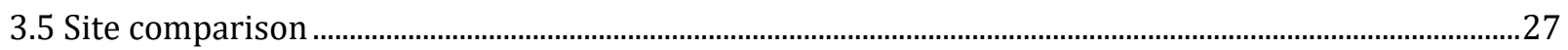

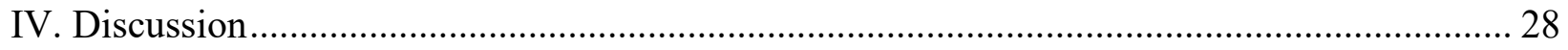

4.1 Iron-oxide accumulation at biogeochemical reactive boundaries..............................................................28

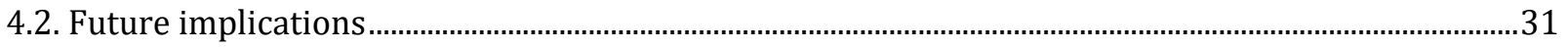

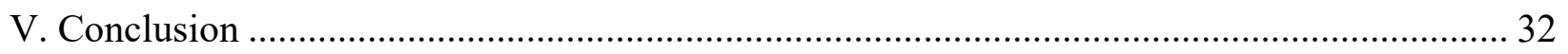

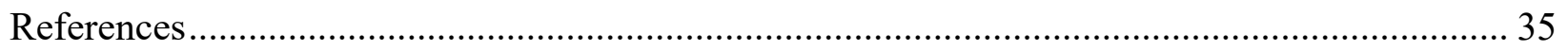

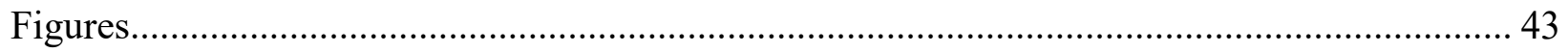

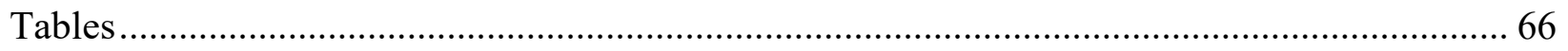

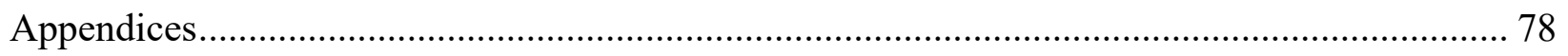

Appendix I: Pore water chemistry results from the Alaskan Peatland Experiment......................................78

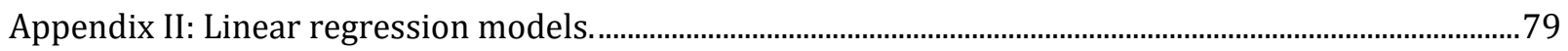




\section{LIST OF FIGURES}

Figure 1. Conceptual model of iron-phosphorus interactions.............................43

Figure 2. Locations of study sites on circumpolar map...................................44

Figure 3. Barrow Environmental Observatory (BEO), study site location......................45

Figure 4. BEO microtopographic features........................................... 46

Figure 5. Collection of 15 soil cores at BEO .......................................47-48

Figure 6. Toolik Field Station (TFS), collection of nine surface samples.....................49

Figure 7. Alaskan Peatland Experiment (APEX), samples collected from experimental plots...50

Figure 8. Marcell Experimental Forest (MEF), 18 surface samples collected from two bogs and

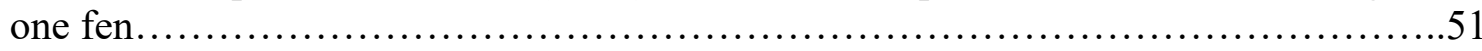

Figure 9. Graph representing average iron fractionation from low-centered and high-centered

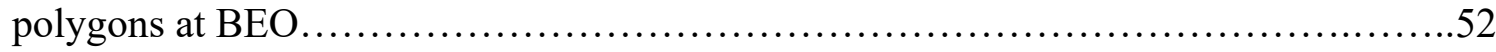

Figure 10. Graphs representing each pool of extracted iron from BEO......................53-54

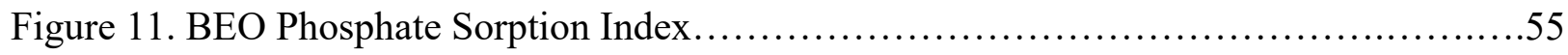

Figure 12. Graph representing average iron fractionation from TFS.........................56

Figure 13. Graphs representing each pool of extracted iron from TFS........................57

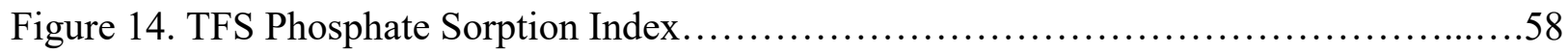

Figure 15. Graph representing average iron fractionation from three experimental plots at

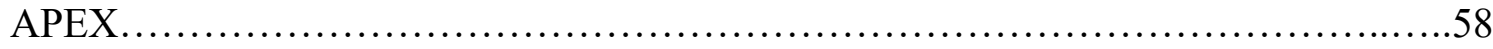

Figure 16. Graphs representing each pool of extracted iron from APEX......................59

Figure 17. APEX Phosphate Sorption Index............................................60

Figure 18. Graph representing average iron fractionation from two bogs and one fen at MEF...60

Figure 19. Graphs representing each pool of extracted iron from MEF.......................61

Figure 20. MEF Phosphate Sorption Index.............................................62

Figure 21. Site comparison of extracted iron fractions...................................62 
Figure 22. Total averaged iron from each fraction amongst all four study sites....

Figure 23. Linear regression models of phosphate sorption index and extracted iron fractions, all

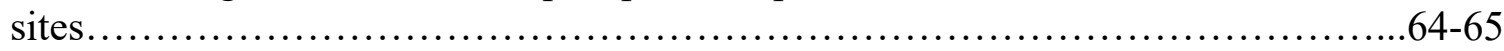




\section{LIST OF TABLES}

Table 1. Barrow Environmental Observatory (BEO) soil core properties...................66

Table 2. References for sequential iron extraction procedure...........................67

Table 3 . Site summary for sequential iron extraction results..........................68

Table 4. Site comparison for soil characteristics including $\mathrm{pH}$, water content, organic content (as loss on ignition) and phosphate sorption index............................... 69

Table 5. Site summary for soil characteristics for BEO ............................... 70

Table 6 . Site summary for sequential iron extraction results from BEO....................71

Table 7. Site summary for soil characteristics for Toolik Field Station (TFS)................72

Table 8 . Site summary for sequential iron extraction results from TFS.....................73

Table 9. Site summary for soil characteristics for Alaskan Peatland Experiment (APEX).......74

Table 10. Site summary for sequential iron extraction results from APEX..................75

Table 11. Site summary for soil characteristics for Marcell Experimental Forest (MEF).......76

Table 12. Site summary for sequential iron extraction results from MEF $\ldots \ldots \ldots \ldots \ldots \ldots \ldots . . .77$ 


\section{ACKOWLEDGEMENTS}

I'd like to give professional thanks to my committee members, Dr. Lauren Kinsman-Costello and Dr. David Singer. Thank you for your endless knowledge, your lab space, and your willingness to help me as needed. Additional professional thanks to Anne Giblin, Stan Wullschleger, and Stephen Sebestyen for their assistance with sample collection, transportation, and continued support throughout my tenure. I'd like to give my greatest personal thanks to my advisor Dr. Elizabeth Herndon for her patience, support, and faith in me. I am extremely thankful for the opportunity to work under a successful, well rounded scientist and to learn and grow throughout my time at Kent State with her as a mentor. The Herndon lab group has not only supported my research efforts but also supported me emotionally and most importantly supported me through friendship. Specifically, thank you to Jonathon Mills for his support and efforts with assisting with phosphate sorption indices and Brianne Yarger for her endless pep-talks and knowledge. Personal thanks to Hayley Buzulencia for keeping me focused and grounded, Kyle Sarven for always brightening my day, and Nichola Merola for his relentless encouragement and unconditional love. Further thanks to my family, specifically my mother, father, and brothers, and to my friends support throughout this experience. This work was supported by a grant through the National Science Foundation to Elizabeth Herndon and Lauren Kinsman-Costello (EAR-1609027) and through a student research award from the Geological Society of America. 


\section{Introduction}

\subsection{Climate change in high-latitude ecosystems}

Boreal forest and tundra biomes cover 28\% of Earth's vegetated surface (23-30.5 million $\mathrm{km}^{2}$ area) and are estimated to account for $50 \%$ of the estimated global belowground organic carbon (C) stocks, (Tarnocai et al. 2009) largely in poorly drained wetlands and permafrost (Turetsky et al. 2008). Wetlands in Northern latitudes can typically be defined as peatlands, or peat covered terrain. Peatlands, which contain primarily organic soils, are defined by the accumulation of partially decayed organic material and require an abundant water supply for most of the year for peatland development (Boelter and Verry, 1977). Organic matter in these peatlands is susceptible to increased decomposition with changing climate. Ecosystems along the $0^{\circ} \mathrm{C}$ mean annual temperature isotherm, such as northern ecosystems included within this study, are sensitive to changing climate given that atmospheric temperatures at higher latitudes are predicted to increase two to four times faster than the rest of the globe (Christensen, 2004; Gates et al. 1983; Holland and Bitz, 2003; Bekryaev et al., 2010). Increases in soil temperature are degrading permafrost, leading to the exposure of previously buried mineral soils, accelerated release of organic compounds and nutrients from permafrost, and increase in rates of organic matter decomposition. These processes may shift these ecosystems from biogeochemical sinks to sources of carbon and increase atmospheric carbon dioxide concentrations (Schuur et al. 2015). Conversely, these biomes have the potential to store more carbon if vegetation growth increases with warming climate. However, the potential for vegetation to store carbon may decrease if the 
plant growth is nutrient limited.

Global climate change and predicted shifts in temperature, precipitation, and seasonality of hydrologic flows will also alter hydrologic regimes of terrestrial ecosystems (Poff et al. 2002).Because of their formation in excessively wet conditions, peatlands remain saturated or nearly saturated under natural conditions (Boelter and Verry, 1977). Changes in precipitation, evapotranspiration, and/or permafrost thaw could increase or decrease soil saturation in different areas (Hinzman et al. 2013). Shifts in water table position and hydrologic fluxes driven by climate change are likely to impact the development and nutrient cycling of developing Northern peatlands. For example, changes in oxygen levels due to changes in moisture conditions can have a large effect on nutrient biogeochemistry, including specifically cycling of phosphorus (P) due to interactions with iron (Fe) (Kinsman-Costello et al. 2014). Basic understanding of nutrient cycling in high latitude ecosystems is of key importance due to both the low productivity and slow nutrient cycling of these areas (Odum, 1969; Jordan and Kline, 1972).

\subsection{Hydrologic impacts on redox potential}

Local hydrological processes in Northern regions are primarily controlled by landscape topography (Frei et al. 2012), runoff from surrounding upland systems (Turetsky et al. 2008; Giblin et al. 1991), and the presence or absence of permafrost (Hinzman et al. 2005; Zona et al. 1992). Permafrost acts as an impermeable layer in the soil that blocks or restricts drainage in many arctic and subarctic regions, resulting in wet surface soils and a relatively high water table (Hinzman et al. 2005). Permafrost-underlain regions will experience shifts in hydrology as permafrost partially or completely thaws to becomes discontinuous, increasing the zone of active water table fluctuation if infiltration is not restricted (Boelter, 1966; Hinzman et al. 2005; Osterkamp and Jorgenson, 2009). Longer snow-free seasons could also contribute to a deeper 
active layer or greater duration of permafrost thaw (Hinzman et al. 2005). The thickness of the active layer, defined as "the top layer of ground subject to annual thawing and freezing in areas underlain by permafrost" (Permafrost Subcommittee, 1988), is important because the majority of hydrological and biogeochemical activity occurs within this zone.

Depending on location, thawing the permafrost barrier is expected to have two consequences on soil saturation: either drying surface soils by lowering the water table (Yoshikawa and Hinzman, 2003; Zona et al. 1992), or saturating surface soils by raising the water table (Jorgenson et al. 2006). Drying of surface soils from the deepening of the water table will expose previously anoxic surface soils to oxic conditions. Increases in evapotranspiration due to increasing plant productivity would also increase drying in surface soils. "Wetting" of surface soils occurs when permafrost thaw induces ground subsidence (thermokarst). This process allows for groundwater to reach the surface or for surface-subsurface flow to collect and pool up in these low-lying areas (Frei et al. 2012; Turetsky 2004; Osterkamp and Romanovsky, 1999; Osterkamp et al. 2000). Redox gradients will shift laterally across this mosaic of wetting and drying landscapes and vertically with increasing thaw depth. This may cause anoxic environments to shift to oxic environments, or vice versa, and influence biogeochemical cycling of metals and nutrients.

\subsection{Iron and phosphorus in the environment}

\subsubsection{Iron biogeochemistry}

Fluctuating water levels in wetlands, peatlands, and other saturated areas control oxidation-reduction (redox) conditions that create biogeochemical boundaries. These redox conditions in turn influence metal cycling and solubility, nutrient cycling, bioavailability, and retention, vegetation, $\mathrm{pH}$, and sediment and organic matter accumulation and decomposition 
(Hinzman et al. 2005). This study focuses on iron (Fe) and phosphorus (P) interactions. Iron plays an important role in geochemical cycles through the formation of iron oxide minerals. The large surface area and reactivity of iron oxide minerals allow for ion sorption. Iron oxides also serve as electron acceptors for anaerobic microbial respiration. Iron cycles between $\mathrm{Fe}(\mathrm{II})$ in zones of anoxia and $\mathrm{Fe}(\mathrm{III})$ in oxic zones. The type and speciation of Fe(III)-oxide minerals formed through $\mathrm{Fe}$ oxidation and hydrolysis may be dependent on factors such as biotic activity, $\mathrm{pH}$, rate of oxidation, temperature, organic matter content, and $\mathrm{Fe}^{2+}$ concentration.

Peat soils in Northern latitude regions often contain high amounts of redox-sensitive iron (Lipson et al. 2013; Herndon et al., 2015a; Herndon et al., 2017). Previous work by Lipson et al. (2010) found abundant dissolved and solid-phase iron in arctic soils. In poorly-drained, reduced soils, $\mathrm{Fe}(\mathrm{II})$ that is mobilized from mineral weathering is soluble and easily redistributed. $\mathrm{Fe}(\mathrm{II})$ may be leached from the soil or migrate upwards in the soil profile towards oxic conditions near the soil surface, precipitating as poorly crystalline ferrihydrite (Zak et al. 2004; Riedel et al. 2012; Herndon et al. 2015a). Fe(II) can also combine with sulfide or phosphate to form minor secondary mineral phases pyrite $\left(\mathrm{FeS}_{2}\right)$ and vivianite $\left(\mathrm{Fe}_{3}\left(\mathrm{PO}_{4}\right)_{2} \cdot 8 \mathrm{H}_{2} \mathrm{O}\right)$ (Roden and Edmonds, 1997). In well-drained oxic soils, Fe(II) can oxidize to Fe(III), which may precipitate out forming Fe(III)-(oxy)hydroxide minerals such as ferrihydrite and goethite (Herndon et al. 2017; Schwertmann, 2008). Fe(III) may also be complexed by organic matter in the organic horizon (Herndon et al. 2015a; Herndon et al. 2017).

Microbial oxidation and reduction strongly control iron reduction and oxidation (Lovley, 1993; Emerson et al. 2015). When oxygen is present, iron-oxidizing bacteria form thick microbial mats at redox interfaces through the oxidation of Fe(II) (Theis and Singer, 1974; Emerson et al. 2015). In the absence of oxygen, iron-reducing bacteria transform Fe(III) to 
reduced iron $(\mathrm{Fe}(\mathrm{II}))$ through anaerobic respiration. In poorly drained soils, microorganisms can also reduce ferric oxides to generate magnetite (Lovley et al., 1987). Frequent cycling or oscillation of Fe between oxidized and reduced forms, such as occurs under fluctuating redox conditions, can promote formation of poorly crystalline Fe-oxides (Slomp et al. 1996; Baldwin, 1996). Poorly crystalline iron oxides, sometimes referred to as amorphous, exhibit the strongest adsorption capacity for phosphate (Borggaard, 1983). Conversely, controlled redox oscillations under flooded conditions converted amorphous Fe oxides to more crystalline forms in laboratory incubations of tropical soils (Thompson et al. 2006). This discrepancy is possibly explained by differences in whether the iron minerals completely or incompletely dissolve during redox fluctuations. If an iron oxide mineral only partially dissolves during anoxia, it may become more crystalline over time. It remains poorly understood how Fe mineralogy responds to fluctuating redox conditions in various environmental settings.

\subsubsection{Phosphorus biogeochemistry}

Phosphorus $(\mathrm{P})$ plays an important role in proper ecosystem functioning and is often a limiting or co-limiting nutrient (Vitousek et al. 2010). Phosphorus exists in ecosystems largely as either inorganic phosphate $\left(\mathrm{PO}_{4}{ }^{3-}\right)$ or bound in organic molecules. Plants assimilate phosphate into organic compounds, including phosphoproteins, enzymes, and energy-rich adenosine triphosphate (ATP). Long chains of phosphate-containing molecules are also responsible for the transmission and storage of genetic information in nucleic acids (DNA and RNA) (Hyland et al. 2005). Because of phosphorus's principal role in biota, lack of gaseous phase, and its general nutrient limitation, soil and water phosphorus dynamics are important for understating ecosystem P-cycling. 
Internal cycling of $\mathrm{P}$ becomes extremely important for the regulation of phosphorus in $\mathrm{P}$ limited ecosystems, such as portions of tundra and boreal ecosystems. Microorganisms and vascular plants demand about 150 times more phosphorus annually than is available as dissolved inorganic $\mathrm{P}$; therefore, $\mathrm{P}$ requirements cannot be fulfilled unless the pool is continually replenished by decomposition or other processes (Chapin, 1978). For example, Chapin et al. (1978) estimated that only $0.03 \%$ of the inorganic $\mathrm{P}$ potentially available for biotic uptake is actually available to plants and microorganisms as dissolved inorganic P. Weathering of primary minerals such as apatite (calcium phosphate) can input inorganic $\mathrm{P}$ into soils, but this process occurs at a very slow rate in in Northern high-latitude systems because of average low temperatures (Hill and Tedrow, 1961; Tedrow and Brown, 1962). Dust and other atmospheric inputs are negligible, and because this system is not in an agricultural or highly populated area, there are generally no fertilizer inputs or runoff, industrial inputs, or other anthropogenic inputs that cause high nutrient loading in other ecosystems. Other P inputs to a given system may include meteoric precipitation and groundwater flow, through which $\mathrm{P}$ can enter the system with suspended solids or as dissolved phosphorus (Ruttenberg, 2013). Inorganic phosphate in soil solution may be transferred to plants where the plant converts the inorganic $\mathrm{P}$ into organic $\mathrm{P}$ through assimilation. Upon plant death, microbes use plant organic matter as an energy source and use phosphatase enzymes to cleave phosphate from organic molecules. This process of decomposition transforms organic $\mathrm{P}$ in plant biomass into inorganic phosphate which is either released into soil solution or incorporated into microbe biomass through microbial assimilation. Cell death also releases organic $\mathrm{P}$ into the environment. Because of low inorganic $\mathrm{P}$ inputs, $\mathrm{P}$ in arctic and boreal ecosystems is tightly cycled through biological systems (Chapin et al. 1978). Phosphate removal from soil solution may occur through plant and microbe uptake and 
incorporation into biomass, adsorption by metal (aluminum and iron) oxides and hydroxides, coprecipitation with carbonates, or complexation with organic matter or other sediments (KinsmanCostello et al. 2014; Richardson, 1985; Johnston, 1991; Walbridge and Struthers, 1993). Most studies in arctic systems focus on biological factors that remove P from soil solution (plant and microbial assimilation) and do not consider factors such as adsorption to mineral surfaces (e.g., Weintraub, 2011).

\subsubsection{Iron-phosphorus interactions}

The biogeochemical interactions between iron and phosphorus are summarized in Figure 1. The ability of a sediment or soil to sequester P is controlled by the capacity of soil minerals to sorb inorganic phosphate molecules (Froelich, 1988). Across soils and sediments from diverse ecosystems and hydrologic regimes, one of the strongest predictors of sediment P sorption is the amount of poorly crystalline $\mathrm{Fe}$ (and/or Al oxides and oxyhydroxides). Poorly crystalline Feoxides have a larger potential for P sorption than more crystalline Fe phases due to their larger surface areas (Slomp et al., 1996). The irregular structures of hydrated oxides and oxyhydroxides (poorly crystalline or amorphous) have a higher surface area and more hydroxyl (-OH) groups for phosphate ions to exchange with. Conversely, minerals with more regular crystal structures have a lower surface area and fewer-OH groups (McLaughlin et al. 1981). It remains unknown how fluctuating redox conditions influence Fe oxide mineralogy, and in turn, phosphate sorption to iron oxides, in arctic systems.

\subsection{Statement of purpose}

The potential for poorly crystalline iron oxides to sequester and limit the pool of bioavailable $\mathrm{P}$ in arctic to subarctic ecosystems remains understudied. This project provides foundational understanding of $\mathrm{Fe}$ geochemistry and $\mathrm{Fe}-\mathrm{P}$ associations in peatland organic and 
mineral soils across a large geographic gradient, spanning from the southern point of a boreal forest in Minnesota to the northernmost point of the United States in the arctic tundra of Alaska. This research addresses the question: How do Fe geochemistry and Fe-P interactions vary across redox and $\mathrm{pH}$ gradients in arctic and subarctic ecosystems? The results have implications for understanding how changes in hydrologic regime driven by climate change will affect the formation of iron oxide precipitates and phosphate adsorption in soils, potentially inhibiting the bioavailability of $\mathrm{P}$ for plant uptake and proper ecosystem functioning. Given that $\mathrm{Fe}$ geochemistry is a likely control on P bioavailability in northern peatlands, this research will increase understanding of geochemical processes in rapidly-changing environments.

Our objective in this study was to characterize the geochemical forms of iron that are present in organic and mineral soils located in topographic highs (relatively unsaturated soils) and lows (relatively saturated soil) of northern peatlands. Additionally, we evaluated the potential for these soils to bind phosphate. Many of these high latitude Northern systems are Plimited, but virtually nothing is known about the role that abiotic factors play in contributing to $\mathrm{P}$ limitation. P solubility in arctic to subarctic ecosystems may be limited by adsorption to poorly crystalline iron oxyhydroxide minerals, becoming less bioavailable to plants (Shen et al. 2011; Sposito, 1990; Borggaard, 1983; Christensen, 2004). We hypothesized that there will be a direct positive correlation between the presence of oxide minerals and the ability of soils to adsorb phosphate. In other words, as the amount of Fe(III)- (oxyhydr)oxide minerals increase, the amount of Fe-bound $\mathrm{P}$ in soil increases.

This study has enabled us to evaluate the potential for P sequestration by the adsorption to iron oxyhydroxides or oxides, and provides preliminary understanding of Fe-P associations in arctic and subarctic peatlands across a latitudinal gradient. There were two main parts to the 
study; 1) Quantify the concentration and form of iron present in redox-sensitive organic-rich peat soils through an iron targeted sequential extraction, and 2) Assess the capacity of soils to immobilize inorganic phosphate using a phosphate sorption assay.

\section{Methods}

\subsection{Field sites}

Iron and phosphorus geochemistry were examined in organic-rich soils from four locations varying in hydrological and climatic regimes (Figure 2). Latitudinal gradients provide a biogeochemical heterogeneous representation of Fe concentrations, P sorption potentials, and plant phosphorus bioavailability due to temperature and saturation differences (Vincent et al. 2014).

\subsubsection{Barrow Environmental Observatory (BEO)}

The Barrow Environmental Observatory (BEO) is located outside of Utqiagvik, AK on the Alaskan North Slope north of the Brooks Range Mountains (Wullschleger et al. 2011) (Figure 3). Annual precipitation at BEO averages $12 \mathrm{~cm}$ with an additional $75 \mathrm{~cm}$ annual snowfall (WRRC, 1949-2005). Average annual air temperature is $-12^{\circ} \mathrm{C}$ and for 317 days of the year the minimum temperature is below freezing (Romanovsky, 2013).

Utqiagvik is an arctic tundra coastal ecosystem characterized by an abundance of lake and interlake landscapes, forming ice-wedge polygons (Hubbard et al. 2013; Brown, 1967). These polygons regulate hydrologic flow paths that form redox gradients across centimeter-scale depths (Zona et al. 1992; Lipson et al. 2012; Newman et al. 2015). Samples were collected from both a low-centered polygon (LCP) and a high-centered polygon (HCP), spanning a hydrological gradient from poorly-drained to well-drained soils, respectively. Low-centered polygons are characterized as having a low-lying center with elevated rims surrounding the depressed center. 
High-centered polygons are characterized as elevated mounds with low-lying depressions surrounding the mounds. (Nichols and Brown, 1980; Herndon et al. 2017) (Figure 4).

Continuous permafrost underlies this area, with an average thaw depth of the active layer ranging from approximately $31-41 \mathrm{~cm}$ (Hinkel et al. 2003). Near maximum thaw depths have been recorded across a low-centered polygon as $57 \mathrm{~cm}$ (trough), $45 \mathrm{~cm}$ (center), and $41 \mathrm{~cm}$ (ridge) (Roy Chowdhury et al. 2015).

Fifteen intact soil cores were extracted (S. Wullschleger) on October 15, 2015 from the active layer of low- and high-center polygons at the Next Generation Ecosystem Experiment (NGEE) intensive field site at the Barrow Environmental Observatory (BEO) (Figure 5).The length of the soil core represents the active layer and thaw depth at the time of sampling, but does not represent the maximum thaw depth. Samples were obtained using a slide hammer equipped with a split soil core sampler (AMS, Inc., American Falls, Idaho). Core depths were reported from the surface of the soil to the maximum sampling depth and ranged from $12.0 \mathrm{~cm}$ to $29.5 \mathrm{~cm}$ (Table 1). From the low-centered polygon, cores were extracted from microtopographic features including ridge (low-centered polygon ridge; LCP-R), trough (low-centered polygon trough; LCP-T), and the center (low-centered polygon center; LCP-C) features. From the highcenter polygon, cores were extracted from microtopographic features including center (highcentered polygon center; HCP-C) and trough (high-centered polygon trough; HCP-T). Three replicate cores were obtained from each location. Once collected, each core was measured for length, photographed, wrapped in aluminum foil, labelled, sealed in plastic bags, and temporarily stored in a $-30^{\circ} \mathrm{C}$ walk-in freezer at the Barrow Arctic Research Center (BARC). Samples were later packed in blue ice and shipped overnight to Kent State University, received on October 22, 2105 , and immediately stored in a $-20^{\circ} \mathrm{C}$ freezer until processing. 


\subsubsection{Toolik Field Station (TFS)}

Toolik Field Station (TFS) is a part of the Long-Term Ecological Research (LTER) network, located around Toolik Lake on the Alaskan North Slope at the foothills of the Brooks Range, AK (Figure 6). Vegetation is dominated by sedges and grasses but have experienced a shift towards woody plants and dwarf bush over the past two decades (Giblin et al. 1991). Toolik Field Station has a mean annual air temperature of about $-10^{\circ} \mathrm{C}$, and $45 \%$ of the $20-40 \mathrm{~cm}$ of precipitation falls as snow. TFS is underlain by continuous permafrost with depth of $\sim 200 \mathrm{~m}$, and only $28-46 \mathrm{~cm}$ of the soil surface thaws annually (EDCT, 2016).

Nine surface organic horizon soils were collected to $<15 \mathrm{~cm}$ depth by hand July $21^{\text {st }} 2015$ near Toolik Lake (Giblin, pers. comm.). Three replicate samples were each collected from tussock tundra and relatively dry hilltop heath in the uplands, and from a low-lying wet sedge tundra zone, similar to those described by Giblin et al. (1991). The tussock tundra is characterized by a maximum thaw depth of $30-50 \mathrm{~cm}$ where in most locations the soils do not thaw down to the mineral soils (Giblin et al. 1991). Near the tussock tundra in the uplands is the heath site, a well-drained, deeply thawed ( $>2 \mathrm{~m}$ depth) mineral soil with a thin organic horizon. Both the tussock tundra and heath sites were located on a relatively high and dry hilltop near but not in the LTER plots. The lowest lying area sampled was a saturated wet sedge site consisting of a thick organic horizon with a maximum thaw depth of $30-50 \mathrm{~cm}$. The samples were collected in whirl-paks, immediately stored at $-80^{\circ} \mathrm{C}$, shipped on dry ice in a cooler, received at Kent State University on November $10^{\text {th }} 2015$, and transferred to a $-20^{\circ} \mathrm{C}$ freezer until processing.

\subsubsection{Alaskan Peatland Experiment (APEX)}

The Alaskan Peatland Experiment (APEX) is positioned in a boreal forest ecosystem, located right outside of the Bonanza Creek Experimental Forest (BCEF). BCEF is a 5053 ha 
research area located about $35 \mathrm{~km}$ southeast of Fairbanks, AK in interior Alaska (Figure 7). Mean annual temperature is $-2.9^{\circ} \mathrm{C}$ and mean annual precipitation is $26.9 \mathrm{~cm}, 30 \%$ of which is snow (Van Cleve et al. 1993a; Hinzman et al. 2005). The APEX site is a moderate-rich fen located within the Tanana River floodplain where greenhouse gas emissions are monitored as a function of hydrology and soil warming (Turetsky et al. 2008). Rich fens represent one of the most common peatland types in western boreal North America (Vitt et al. 2006). The site lacks microtopography (e.g., hummocks and hollows) and maximum peat depth is approximately $1 \mathrm{~m}$ (Turetsky et al. 2008). Three large experimental plots $(20 \mathrm{x} 20 \mathrm{~m})$ were created in 2004. Each plot was assigned to a water table treatment condition including a control, lowered, and a raised water table treatment. In 2005, a solar-powered bilge pump was installed to pump water into the raised water table plot and an excavator was used to create drainage channels $(\sim 40 \mathrm{~cm}$ wide, 1 $\mathrm{cm}$ deep) to lower the water table position. The water table in the raised treatment was observed to remain near the peat surface and was higher than the water tables in the control and drained plots, which were measured at $\sim 7 \mathrm{~cm}$ and $\sim 10 \mathrm{~cm}$ below the peat surface, respectively, during the growing seasons between 2005-2008 (Kane et al. 2010). However, periodic flooding conditions, including during the time of sampling, resulted in uniformly high water tables above the fen.

Three replicate soil cores were collected from each treatment plot in late July 2016. Soil cores were extracted using a 1" diameter drill-powered auger and collected from the base of the living vegetation down to the point of refusal, which ranged between $55.5 \mathrm{~cm}$ and $64 \mathrm{~cm}$.

Refusal occurred when the peat soil became too compact to drill through. The auger was removed from the peat and the core was extracted onto aluminum foil where it was then gently stretched by hand to offset compaction that occurred during coring. The core was measured for length, wrapped in aluminum foil, and placed into plastic storage bags with excess air removed 
and closed with twist ties. The packaged cores were immediately stored in a cooler on ice for the remainder of the day, then stored in a freezer until shipment to Kent State University on dry ice. Upon arrival to Kent State University cores were stored in a freezer at $-20^{\circ} \mathrm{C}$ until soil processing.

At each of the manipulated water table sites, a thin metal rod with a mesh screen was inserted into the ground to depths of $20 \mathrm{~cm}, 40 \mathrm{~cm}$, or $70 \mathrm{~cm}$ from the peat surface. Water chemistry results are summarized in Appendix A. A syringe with plastic tubing was inserted into the rod and used to draw up pore water from each depth at each site $(n=21)$. Surface water samples were collected from each plot by submerging a $250 \mathrm{ml}$ plastic bottle into the water pooled above the peat surface. Surface water and pore water samples were filtered with $0.22 \mu \mathrm{m}$ Supor with $0.7 \mathrm{um} \mathrm{GF/F} \mathrm{pre-filters} \mathrm{on} \mathrm{site.} \mathrm{The} \mathrm{filtered} \mathrm{sample} \mathrm{was} \mathrm{aliquoted} \mathrm{into} \mathrm{samples} \mathrm{A,} \mathrm{B,}$ and C. Approximately $30 \mathrm{ml}$ of filtered surface water was aliquoted into a $60 \mathrm{ml}$ plastic bottle and acidified with 2-3 drops of ultrapure nitric acid for cation analyses (A sample), $\sim 30 \mathrm{ml}$ of filtered water sample was aliquoted into a $60 \mathrm{ml}$ plastic bottle (B sample), and $20 \mathrm{ml}$ of filtered sample water was aliquoted into $40 \mathrm{ml}$ amber glass vials and acidified with 2-3 drops of ultrapure hydrochloric acid (C sample). Ultrapure nitric acid was added to A samples to prevent metal precipitation, and hydrochloric acid was added to $\mathrm{C}$ samples to remove inorganic carbon and inhibit microbial activity. The A, B, and C samples were stored in a refrigerator overnight until shipped to Kent State University on dry ice where they were stored in a refrigerator until analyses. An electroconductivity (EC) meter was used on unfiltered sample water from each site to measure conductivity $\left(\mu \mathrm{S} \mathrm{cm}^{-1}\right)$ and temperature $\left({ }^{\circ} \mathrm{C}\right)$. A portable $\mathrm{pH}$ probe was calibrated on site with 4.1 and 7.0 standards and was used to measure $\mathrm{pH}$ in unfiltered water.

\subsubsection{Marcell Experimental Forest (MEF)}


The Marcell Experimental Forest (MEF) is an 890 ha research area that sits at the southern margin of a boreal peatland forest biome in Northern Minnesota, about $40 \mathrm{~km}$ north of the Grand Rapids, MN (Figure 8). The MEF contains six experimental watersheds (5 bogs, 1 fen), each consisting of an upland portion and a peatland that is the source of a stream leaving the watershed (Sebestyen et al. 2011). Annual precipitation averages $78 \mathrm{~cm}$ with one-third accounted for as snow. Mean annual temperature since 1961 is $3.4^{\circ} \mathrm{C}$ with monthly average temperatures between 16 and $19^{\circ} \mathrm{C}$ in June, July, and August, and between -11 and $-15^{\circ} \mathrm{C}$ in December, January, and February (USDA Forest Services, 2012).

Eighteen surface soils were collected from across three sites (Site 1 bog, Site 2 bog, Site 3 fen; S1, S2, S3) within the Marcell Experimental Forest on October 15 $5^{\text {th }}, 2015$ relatively close to the outlet of each peatland (Sebestyen, pers. comm.). The S1-bog is a black spruce bog surrounding Spruce and Peatland Responses Under Climatic and Environmental Change experiment site (SPRUCE). Water levels are more variable at the S1-bog than the other peatlands, fluctuating from several centimeters above the peat surface in hollows to a maximum depth of $1.4 \mathrm{~m}$ (Sebestyen et al. 2011). At the time of sampling, the water table was within $15 \mathrm{~cm}$ of the hollow surface at Site 1. The S2-bog is also a black spruce bog that includes several tamarack. At the time of sampling, the water table was below $20 \mathrm{~cm}$ of the hollow surface. Sample Site 3 watershed was characterized as a fen ecosystem (S3-fen). Samples were collected in a stand of tamarack with tamarack needles fallen on the surface site. The water table was practically at the hollow surface during sample collection. Triplicate samples were collected from hummock and hollow microtopographic features at each site. Hummocks are typically elevated and dry relative to depressed and saturated hollows. Samples were collected within about a 1x1 m area from the base of living Sphagnum moss to $\sim 20 \mathrm{~cm}$ depth with a 3" stainless 
steel drill corer with a serrated bottom edge. A knife was used to cut around the corer when drilling began to create a cleaner coring at the surface. Samples were shipped frozen and received at Kent State University on October $16^{\text {th }}, 2015$, then immediately stored at $-20^{\circ} \mathrm{C}$ until soil processing.

\subsection{Soil processing and preparation}

Frozen soil cores and bulk surface soils were thawed and processed in a vinyl anaerobic chamber with $\mathrm{N}_{2}$ atmosphere containing at least $1.0 \% \mathrm{H}_{2}$ and less than $1 \mathrm{ppm} \mathrm{O}_{2}$. Large roots and other green vegetation were removed from the soils before processing.

The Barrow Environmental Observatory $(\mathrm{BEO})$ cores $(\mathrm{n}=15)$ were removed from their plastic bags and aluminum foil and placed onto a tray. A multipurpose oscillating power tool was used to split cores into an upper organic horizon and a lower mineral horizon. The interface was determined by visual color changes and textural differences within each core. The organicmineral boundary varied between $8-14 \mathrm{~cm}$ bgs depending on location of soil core collection. The cores from the low centered-polygon center (LCP-center) contained only organic material and therefore, were not divided into horizons (organic horizon only). Each horizon was then split into $\sim 4 \mathrm{~cm}$ depth increments, which were homogenized and subsampled for later geochemical analysis $(n=66$ subsamples). Subsamples were air-dried in the anaerobic chamber, lightly ground with a mortar and pestle, and stored in a sample bag in the anaerobic chamber. The remaining wet soil from each depth increment was homogenized by horizon and partitioned into subsamples for physical and chemical characterization (described below). Subsamples of the homogenized soil horizons were weighed into $50 \mathrm{ml}$ Falcon tubes, $15 \mathrm{ml}$ centrifuge tubes, and/or aluminum weigh boats for various geochemical analyses. The remainder was refrozen at $-20^{\circ} \mathrm{C}$. 
The Alaskan Peatland Experiment (APEX) cores $(\mathrm{n}=9)$ were split into two sections; < $20 \mathrm{~cm}$ and $>20 \mathrm{~cm}$ depth. This depth corresponds to the approximate depth of peat that experiences seasonal water table variation, although the extent and variability of water table fluctuations varied amongst plots (Kane et al. 2010). Each core was then divided into $\sim 10 \mathrm{~cm}$ depth increments with an oscillating power tool and a small portion of each depth increment was removed, air-dried in an anaerobic chamber, lightly ground with a mortar and pestle, and stored in a sample bags in the anaerobic chamber for later analyses $(\mathrm{n}=51)$. The remaining soil from each section was homogenized and subsamples of the homogenized soil horizons were weighed into $50 \mathrm{ml}$ Falcon tubes, $15 \mathrm{ml}$ centrifuge tubes, and/or Al weigh boats for various geochemical analyses. The remainder was refrozen at $-20^{\circ} \mathrm{C}$.

Surface soil samples from the Marcell Experimental Forest (MEF, n=18) and the Toolik Field Station (TFS, $\mathrm{n}=9$ ) were stored frozen until processing, thawed in an anaerobic chamber, homogenized, and divided into subsamples for analyses. The remainder was refrozen at $-20^{\circ} \mathrm{C}$.

\subsection{Laboratory methods}

\subsubsection{Bulk soil characterization}

To determine soil $\mathrm{pH}, 5 \mathrm{ml}$ of $1 \mathrm{M}$ potassium chloride $(\mathrm{KCl})$ solution was added to $1.0 \pm$ $0.05 \mathrm{~g}$ of soil in a $15 \mathrm{ml}$ metal-free centrifuge tube in the anaerobic chamber to yield a 1:5 soil: $\mathrm{KCl}$ slurry. Potassium ions displace $\mathrm{H}^{+}$ions from soil exchange sites, releasing adsorbed $\mathrm{H}^{+}$ into solution and providing a better representation of soil acidity than soil $\mathrm{pH}$ measured in distilled water (Rayment and Higginson, 1992). The $1 \mathrm{M} \mathrm{KCl}$ solution was boiled under $\mathrm{N}_{2}$ gas to remove dissolved $\mathrm{O}_{2}$ gas prior to use. The soil slurries were shaken by hand, left to stand for 10 minutes, removed from the anaerobic chamber, and $\mathrm{pH}$ was recorded to the nearest $0.01 \mathrm{pH}$ unit using a benchtop $\mathrm{pH}$ meter. The $\mathrm{pH}$ electrode was rinsed with DI water between $\mathrm{pH}$ 
readings and the $\mathrm{pH}$ meter was calibrated using 4.1 and 7.0 buffer standards.

The oven-drying method was used to determine soil gravimetric water content by recording mass loss of the sample following drying. During soil processing in the anaerobic chamber, triplicates of $\sim 5-7 \mathrm{~g}$ of wet soil were placed into aluminum weigh boats, then removed from the anaerobic chamber and transferred into a drying oven at $105^{\circ} \mathrm{C}$ for 24 hours (Gardner, 1986). Soil mass was recorded before and after oven drying and water content $\left(\mathrm{g} \mathrm{H}_{2} \mathrm{O}\right.$ g dry soil-

$\left.{ }^{1}\right)$ was calculated by dividing the difference between wet soil mass and dry soil mass $\left(\mathrm{g} \mathrm{H}_{2} \mathrm{O}\right)$ by the mass of the dry sample (g). Oven-dried triplicates were combined, lightly ground with an agate mortar and pestle, and placed into whirl-pack sample bags for storage and loss-on-ignition analyses. Loss-on-ignition (LOI, \%) was performed to estimate soil organic content in the samples. Approximately $0.5 \mathrm{~g}$ of oven-dried soil was transferred into a pre-weighed empty $20 \mathrm{ml}$ porcelain crucible and re-weighed. The crucibles were combusted in a Thermo Scientific Thermodyne muffle furnace at $550^{\circ} \mathrm{C}$ for four hours (Sparks, 1996). The samples were removed and reweighed to record the mass of the residual soil (ash), or remaining mass after combustion. LOI was calculated by dividing the difference between the pre-ashed mass and ashed mass (mass loss $(\mathrm{g})$ ) by the mass of the pre-ashed sample (g), and multiplied by 100 to get a percentage.

\subsubsection{Iron sequential extractions}

An iron sequential extraction was performed to quantify different pool of soil iron phases. The sequential extraction has been modified from Amacher et al. (1990), Siregar et al. (2005), Tessier et al. (1979), and Poulton and Canfield (2005) for use on peat soils by including a step for removal of organic matter (Table 2). This specific iron extraction targeted exchangeable Fe (Ex $\sim \mathrm{Fe}$; loosely sorbed molecules), organic bound $\mathrm{Fe}$ (Org Fe; iron ions complexed by organic matter), poorly crystalline Fe oxide (PXL Fe; ferrihydrite, lepidocrite), crystalline Fe oxide 
(XL Fe; hematite, goethite), and magnetite $\mathrm{Fe}$ fractions ( $\mathrm{Mag} \sim \mathrm{Fe} ; \mathrm{Fe}_{3} \mathrm{O}_{4}$ ). The remaining fraction after the conclusion of the extraction was characterized as residual iron (silicate minerals).

The first targeted pool of iron extracted used $10 \mathrm{ml}$ of $\mathrm{N}_{2}$-degassed barium chloride and ammonium chloride $\left(0.1 \mathrm{M} \mathrm{BaCl}_{2}-\mathrm{NH}_{4} \mathrm{Cl}\right)$ to extract exchangeable $\mathrm{Fe}$, i.e., $\mathrm{Fe}$ that is loosely bound to organic and mineral surfaces. This step was performed in the anaerobic chamber where the $0.1 \mathrm{M} \mathrm{BaCl}_{2}-\mathrm{NH}_{4} \mathrm{Cl}$ solution was added to the $\sim 1.0 \mathrm{~g}$ of thawed soil sample and mixed for 20 minutes on a mechanical rotator. The slurry was centrifuged at $4000 \times g$ for 30 minutes, and the supernatant was filtered $(<0.45 \mu \mathrm{m}$ nylon syringe filter) into $50 \mathrm{ml}$ metal-free Falcon tubes and acidified with 2-3 drop of highly concentrated ultrapure nitric acid (Amacher et al. 1990). All remaining steps were performed outside of the anaerobic chamber.

The second fraction extracted iron bound to organic matter ( $\mathrm{Org} \sim \mathrm{Fe})$, representing iron strongly complexed by organics molecules or present in biomass. A sodium hypochlorite ( $\mathrm{NaClO}$, household bleach) extraction method from Siregar et al. (2005) was compared to the hydrogen peroxide $\left(\mathrm{H}_{2} \mathrm{O}_{2}\right)$ method in Tessier et al. (1979) protocol on previous samples from the Barrow Environmental Observatory (Herndon et al. 2017). Sodium hypochlorite has been determined to remove organic matter while not significantly altering or dissolving iron oxide mineral phases. Therefore, the organic matter bound iron fraction was removed with $10 \mathrm{ml}$ $\mathrm{NaClO}(6 \%$ active $\mathrm{Cl})$ acidified with ultrapure hydrochloric acid to a $\mathrm{pH}$ of 8 .

The remaining extractions were based on the protocol by Poulton and Canfield (2005). Poorly crystalline iron oxide mineral phase was extracted with $10 \mathrm{ml}$ of $1 \mathrm{M}$ hydroxylamine- $\mathrm{HCl}$ in $25 \% \mathrm{v} / \mathrm{v}$ acetic acid for 48 hours (PXL Fe). This extraction is meant to target ferrihydrite and lepidocrocite, but may also extract poorly crystalline goethite phases. Crystalline iron oxides 
(e.g., hematite and crystalline goethite) were extracted with freshly prepared citrate-buffered sodium dithionite $(50 \mathrm{~g} / \mathrm{L}$ sodium dithionite in $0.35 \mathrm{M}$ acetic acid and $0.2 \mathrm{M}$ sodium citrate buffer solution at $\mathrm{pH} 4.8)$ after mixing on the end-over-end rotator for 2 hours (XL $\sim \mathrm{Fe})$. The magnetite $\left(\mathrm{Fe}_{3} \mathrm{O}_{4}\right)$ fraction was extracted with a $0.2 \mathrm{M}$ ammonium oxalate and $0.17 \mathrm{M}$ oxalic acid solution at $\mathrm{pH} 3.2$ after 6 hours on the end-over-end rotator $(\mathrm{Mag} \sim \mathrm{Fe})$. Between sequential extraction step, soils were rinsed and vortexed with $10 \mathrm{ml} 0.01 \mathrm{M} \mathrm{KCl}$ solution, then centrifuged at $4000 \times \mathrm{g}$ for 30 minutes. The supernatant was filtered with a $<0.45 \mu \mathrm{m}$ syringe filter and combined with the extract. All extracts and matrix standards were stored at $4^{\circ} \mathrm{C}$ until analyses.

\subsubsection{Phosphate sorption experiments}

Phosphate sorption experiments are used to quantify a soil's ability to sorb phosphate by measuring how much of a known quantity of phosphate adsorbs onto soil or remains in solution (Griffin, 1982; Froelich, 1998). The phosphate sorption index (PSI) is a single-point adsorption value that provides a comparative measure of phosphate adsorption capacity across soils (Bache and Williams, 1971). Here, $\sim 4 \mathrm{~g}$ of wet soil from each soil horizon were weighed into $50 \mathrm{ml}$ metal-free centrifuge tubes in the anaerobic chamber. Each soil was mixed with $20 \mathrm{ml}$ of $75 \mathrm{mg}$ $\mathrm{L}^{-1} \mathrm{P}$ solution $\left(\right.$ as $\left.\mathrm{KH}_{2} \mathrm{PO}_{4}\right)$ and placed on a mechanical rotator for 24 hours. Soil-solution suspension was filtered through a $0.45 \mu \mathrm{m}$ Supor filter with a $0.7 \mu \mathrm{m}$ glass fiber prefilter.

Dissolved phosphate was measured using the molybdate blue method by reacting a $100 \times$ diluted aliquot of the filtered solution with PhosVer 3 reagent (Hach) and measuring absorbance at 880 $\mathrm{nm}$ on a UV-Visible spectrophotometer (Shimadzu UV-1800). Absorbance values were converted to concentrations using a linear regression of absorbance as function of concentration in calibration standards $\left(0.007-0.815 \mathrm{mg} \mathrm{L}^{-1} \mathrm{P}\right.$ as $\left.\mathrm{KH}_{2} \mathrm{PO}_{4}\right)$. Phosphate sorbed or released by the soil was calculated as the difference between the phosphate concentration of initial solution 
and final dissolved phosphate. The residual soil was dried at $105^{\circ} \mathrm{C}$ for 24 hours to determine dry soil mass $(\mathrm{g})$. The amount of $\mathrm{PO}_{4}{ }^{3-}$ sorbed to the soil $\left(\mathrm{P}_{\text {sorbed; }} \mathrm{mg} \mathrm{g}^{-1}\right)$ was calculated as the difference between the initial and final dissolved $\mathrm{PO}_{4}{ }^{3-}$ mass in solution normalized to the dry soil mass. The phosphate sorption index (PSI) is calculated as the ratio of sorbed $\mathrm{P}$ to dissolved $\mathrm{P}$ (Bache and Williams, 1971):

$$
P S I=100 \times \frac{P_{\text {sorbed }}}{\log \left(P_{\text {dissolved }}\right)}
$$

Here, $P_{\text {dissolved }}\left(\mu \mathrm{mol} \mathrm{L}{ }^{-1}\right)$ is the final concentration of dissolved $\mathrm{P}$ (as phosphate) in solution.

\subsection{Geochemical analyses and data preparation}

Element concentrations in the sequential iron and phosphorus extracts were measured by inductively coupled plasma optical emission spectrophotometry (PerkinElmer 8000, ICP-OES). All organic fraction extracts from the iron extraction procedure ( $\mathrm{Fe} \sim \mathrm{Org}$ ) were diluted $10 \mathrm{X}$ by pipetting $1 \mathrm{~mL}$ of extract into $9 \mathrm{~mL}$ milli-Q water. Other extracts were diluted when necessary with either milli-Q water or $\sim 2 \%$ nitric acid solution. Element concentrations in soil extracts were analyzed against standard curves of $0.01,0.10,1,2.5,5,10,25$, and $50 \mathrm{mg} / \mathrm{L}$ prepared in the extract solution (matrix standards). Method blanks were analyzed to evaluate potential contamination from extraction chemicals. When averaging across samples, a value of half the lowest calibration standard was used to represent concentrations that were below the detection limit. For example, if the lowest standard was $0.010 \mathrm{mg} / \mathrm{L}, 0.005 \mathrm{mg} / \mathrm{L}$ was used in calculations to represent values below the detection limit.

Calculations and data processing from ICP-OES was performed using Microsoft Excel. Element concentrations in extract solutions $\left(\mathrm{mg} \mathrm{L}^{-1}\right)$ were converted to soil concentrations (mg g-dry soil ${ }^{-1}$ ) by multiplying by extract volume (L) and dividing by dry soil mass (g), accounting 
for any dilutions during ICP-OES analysis. All element concentrations in soil extracts are reported per mass of dry soil. Because extraction procedures were performed using wet samples, water content ( $\mathrm{g} \mathrm{H}_{2} \mathrm{O}$ g-dry soil ${ }^{-1}$ ) was used to convert wet soil mass (g) to dry soil mass (g) using the equation:

$$
\operatorname{dry} \operatorname{soil} \text { mass }(g)=\text { wet soil mass }(g)\left(\frac{1}{1+\text { water content }\left(\mathrm{g} \mathrm{H}_{2} \mathrm{O} \text { gdry soil }^{-1}\right)}\right)
$$

Concentrations of ferrous iron $\left(\mathrm{Fe}^{2+}\right)$ in APEX pore waters (Appendix A) were determined by the 1,10-phenanthroline method (Hach Method 8146) on a UV-Visible spectrophotometer (Shimadzu UV-1800). The colorimetric indicator 1,10-phenanthroline turns orange when it complexes Fe(II) and absorbs light with a wavelength of $510 \mathrm{~nm}$. The amount of light that is absorbed is directly proportional to the concentration of Fe(II) bound to 1,10phenanthroline. Precisely $5 \mathrm{ml}( \pm 0.5 \mathrm{ml})$ of filtered, $\mathrm{HNO}_{3}$-acidified water was measured into a graduated cylinder. Distilled deionized water (DDI water) was added to the graduated cylinder to a total volume of $25 \mathrm{~mL}$. The $25 \mathrm{~mL}$ solution was poured into a $50 \mathrm{ml}$ centrifuge tube. A Ferrous Iron Reagent Powder Pillow (Hach) was added to the centrifuge tube and allowed to react for three minutes. After three minutes, the solution was poured into a clean quartz cell and placed into the spectrophotometer. Absorbance was recorded at $510 \mathrm{~nm}$. Concentrations of dissolved Fe $\left(\mathrm{Fe}^{3+}+\mathrm{Fe}^{2+}\right), \mathrm{Al}^{3+}, \mathrm{Ca}^{2+}$, and $\mathrm{P}$ in soil pore waters from APEX were also measured using ICPOES.

Soil properties for each sample site are reported as the mean \pm standard error of the mean for values measured on three replicate soils from each site. Standard error was calculated as followed: 


$$
\text { Standard Error }=\frac{S D}{\sqrt{n}}
$$

where SD is the standard deviation of the samples and $\mathrm{n}$ is the number of samples.

A simple linear regression statistical model was performed to examine the dependence of extracted $\mathrm{Fe}$ concentrations on soil $\mathrm{pH}$ and of the phosphate sorption index on $\mathrm{pH}$ and extracted Fe concentrations. Statistics were performed on log value of Fe concentrations. Results were considered significant if the p-value was $<0.05$.

\section{Results}

Total extracted iron concentrations $\left(\mu \mathrm{g} \mathrm{g}^{-1}\right)$ and percentages of $\mathrm{Fe}$ in each fraction $(\%)$ in soils from across the four study sites were examined (Table 3). Poorly crystalline oxyhydroxide associated iron represents the largest fraction of averaged iron extracted across the four study sites at almost 50\% (Fe PXL: 8,103 $\left.\pm 2,760 \mu \mathrm{g} \mathrm{g}^{-1} ; 49.2 \%\right)$. Organic bound iron (Fe Org: 3,760 $\pm 422 \mu \mathrm{g} \mathrm{g}^{-1} ; 22.8 \%$ ) and crystalline iron oxides (Fe XL: 3,368 $\pm 1,249 \mu \mathrm{g} \mathrm{g}^{-1} ; 20.5 \%$ ) also represent dominant fractions while comparing the four study sites. Exchangeable (Fe Exch; $\left.1,035 \pm 286 \mu \mathrm{g} \mathrm{g}^{-1} ; 6.3 \%\right)$ and magnetite associated iron (Fe Mag; $197 \pm 34 \mu \mathrm{g} \mathrm{g}^{-1} 1 ; 1.2 \%$ ) comprised small proportions of total Fe compared to the other fractions, although exchangeable Fe was more dominant at certain individual sites. Below, trends in Fe speciation and correlations with phosphate sorption indices across topographic features at each site are discussed.

\subsection{Barrow Environmental Observatory}

Here, results from the averages of organic horizons across all topographic features within the low-centered polygon ( $\mathrm{LCP}-\mathrm{O})$ and high-centered polygon ( $\mathrm{HCP}-\mathrm{O})$ are presented. Average soil $\mathrm{pH}$ and gravimetric water content were similar for the LCP and HCP organic horizons $(\mathrm{pH}=$ 
$4.43 \pm 0.11$ and $4.45 \pm 0.13$; water content $=4.06 \pm 0.99$ and $3.74 \pm 1.49 \mathrm{~g} \mathrm{H}_{2} \mathrm{O}$ g-soil $\left.{ }^{-1}\right)($ Table 4). Although variable across all features, loss on ignition averaged $21 \%$ higher in the LCP (LOI $=65 \pm 13 \%)$ soils than in the HCP soils $(44 \pm 22 \%)$.

Total concentrations of extracted Fe were comparable between low-centered organic $\left(20,339 \pm 3,434 \mu \mathrm{g}\right.$ g-soil $\left.{ }^{-1}\right)$ and high-centered organic $\left(20,086 \pm 5,076 \mu \mathrm{g}\right.$ g-soil $\left.^{-1}\right)$ horizons (Table 5). Exchangeable iron, organic-bound, and poorly crystalline iron oxyhydroxide fractions comprised the majority of extracted iron in all features, while lesser concentrations of Fe were present in crystalline and magnetite fractions (Figure 9). In LCP-O horizons, the largest pool of

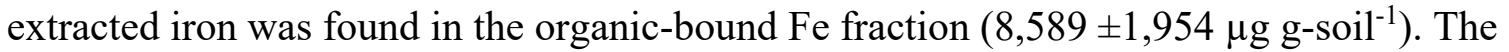
greatest percentages of total extracted iron were represented in the organic-bound $\mathrm{Fe}(42 \%)$ and poorly crystalline (37\%) fractions. In HCP-O horizons, the highest concentrations of Fe were present in the poorly crystalline iron oxides $\left(9,406 \pm 5,375 \mu \mathrm{g}\right.$ g-soil $\left.{ }^{-1}\right)$ and highest percentages of Fe extracted were in the poorly crystalline (47\%) and organic bound (33\%) iron oxides (Figure $10)$.

Organic horizons in the low-centered polygon exhibited a higher capacity to sorb phosphate (Phosphate Sorption Index $=72.4 \pm 10.9)$ than in the high-centered polygons $(\mathrm{PSI}=$ $48.9 \pm 14.4)$ (Figure 11). Across all BEO soils, PSI was positively correlated with the concentration of organic-bound Fe, but not any other forms of Fe. Due to the dominant presence of organic-bound iron in low-centered polygons and the associated greater PSI, for our soil samples at Barrow Environmental Observatory, we see a trend towards the prominent role of organic-bound $\mathrm{Fe}$ in sequestering phosphate.

\subsection{Toolik Field Station (TFS)}


Average soil $\mathrm{pH}$ ranged from 4.99 to 6.16 across the three sites near Toolik Field Station. The wet sedge site $(6.16 \pm 0.07)$ was less acidic than the tussock tundra $(5.40 \pm 0.05)$, and the heath soils were the most acidic $(4.99 \pm 0.24)$ (Table 7). The gravimetric water content follows the same trend as $\mathrm{pH}$ with highest values in wet sedge soils $\left(6.32 \pm 0.15 \mathrm{~g} \mathrm{H}_{2} \mathrm{O}\right.$ g-soil $\left.{ }^{-1}\right)$, followed by tussock tundra $\left(3.13 \pm 0.15 \mathrm{~g} \mathrm{H}_{2} \mathrm{O}\right.$ g-soil $\left.{ }^{-1}\right)$, and lowest at the heath site $(0.56 \pm 0.05$ $\mathrm{g} \mathrm{H}_{2} \mathrm{O}$ g-soil $\left.{ }^{-1}\right)$. The water content was consistent with the hillside topographic sequence of the TFS with wet sedge being the lowest lying area, and heath representing the topographic high. Tussock tundra soils had the highest organic content, measured by loss on ignition $(89 \pm 0.71 \%)$, compared to the heath $(44 \pm 12 \%)$, and wet sedge $(58 \pm 0.81 \%)$ sample locations.

Total extracted Fe was over 20 times higher in the wet sedge soils $(165,626 \pm 21,747 \mu \mathrm{g}$ g-soil $\left.{ }^{-1}\right)$ than the heath $\left(7,932 \pm 1,970 \mu \mathrm{g} \mathrm{g}\right.$-soil $\left.{ }^{-1}\right)$ and tussock tundra sites $(2,562 \pm 232 \mu \mathrm{g} \mathrm{g}$ soil $^{-1}$ ) (Table 8; Figure 12). The largest percentage and concentration of Fe extracted at the wet sedge site was represented by the poorly crystalline Fe (oxyhydr)oxides $(67 \% ; 111,671 \pm 30 \mu \mathrm{g}$ g-soil ${ }^{-1}$ ) while crystalline oxides comprised the largest concentration and percentage in heath soils $\left(75 \% ; 10,588 \pm 7,741 \mu \mathrm{g} \mathrm{g}^{-1}\right)$. The tussock tundra's largest pool of extracted iron was organic-bound Fe $\left(47 \% ; 1,211 \pm 199 \mu \mathrm{g} \mathrm{g}^{-1}\right)$ (Figure 13).

Wet sedge soils had substantially higher PSI $(158 \pm 11)$ than soil from the tussock tundra $(11 \pm 0.84)$ and heath $(14 \pm 1.63)$ soils (Figure 14). There was an apparent trend towards lowlying wet sedge site characterized by a circumneutral $\mathrm{pH}$, greatest overall total iron and poorly crystalline Fe concentrations, and highest PSI, whereas the upland heath and tussock tundra sites had less Fe and lower PSI.

\subsection{Alaskan Peatland Experiment (APEX)}


Soils collected from the lowered, raised, and control water table treatment plots within the Alaskan Peatland Experiment fen showed little variance in both bulk soil characteristics and geochemical parameters (Table 9, Table 10, Figure 15). Results for pore water geochemical analysis can be found in Appendix I. Soil $\mathrm{pH}$ averaged $4.53 \pm 0.08$ across all plots and ranged from $4.43 \pm 0.06$ in the control plot to $4.70 \pm 0.05$ in the raised plot. The gravimetric water content averaged $4.91 \pm 0.69 \mathrm{~g} \mathrm{H}_{2} \mathrm{O}$ g-soil ${ }^{-1}$ across all three plots and ranged from $4.84 \pm 2.09 \mathrm{~g}$ $\mathrm{H}_{2} \mathrm{O}$ g-soil ${ }^{-1}$ in the raised plot to $5.15 \pm 0.95 \mathrm{~g} \mathrm{H}_{2} \mathrm{O}$ g-soil ${ }^{-1}$ in the control plot. Organic content ranged between $81 \pm 1.8 \%$ in the control plot to $83 \pm 1.3 \%$ in the lowered plot, averaging $82 \% \pm$ $1.3 \%$.

Due to the minimal differences in Fe concentrations and percentages among the three plots, the Fe extraction results are presented and interpreted as the average across the three treatment plots. The total average concentration of iron extracted was $5,829 \pm 234 \mu \mathrm{g} \mathrm{g}$-soil ${ }^{-1}$. The averaged iron concentrations in the organic-bound fraction $\left(4,652 \pm 75 \mu \mathrm{g} \mathrm{g}^{-1}\right)$ were much higher than in poorly crystalline iron oxides $\left(734 \pm 61 \mu \mathrm{g} \mathrm{g}^{-1}\right)$, exchangeable Fe (307 $\pm 36 \mu \mathrm{g} \mathrm{g}^{-}$

${ }^{1}$ ), crystalline iron oxides $\left(93 \pm 9.3 \mu \mathrm{g} \mathrm{g}^{-1}\right)$, and magnetite $\mathrm{Fe}\left(43 \pm 2.2 \mu \mathrm{g} \mathrm{g}^{-1}\right)$ (Figure 16).

Organic-bound iron represented $80 \%$ of the total extracted iron, consistent with the high organic content represented by the loss on ignition. Poorly-crystalline (oxyhydr)oxides represented the second highest pool of iron (13\%). The phosphate sorption index was $51.4 \pm 2.5$, indicating a moderate ability for the organic soils at APEX to sequester phosphate relative to the other sites (Figure 17).

\subsection{Marcell Experimental Forest (MEF)}

Soil pH ranged between 2.95 to 6.40 amongst the three sites at the Marcell Experimental Forest (Table 11). Soils from the Site $1 \mathrm{bog}(\mathrm{pH}=3.03 \pm 0.59)$ and Site 2 bog $(2.95 \pm 0.46)$ were 
more acidic than the circumneutral Site 3 fen $(\mathrm{pH}=6.29 \pm 0.45)$. Site 3 fen soils had lower organic content $(\mathrm{LOI}=84 \pm 1.7 \%)$ compared to $\mathrm{S} 1$ and $\mathrm{S} 2-$ bogs $(\mathrm{LOI}=93 \pm 3.1 \%$ and $94 \pm$ $1.3 \%$, respectively). Comparing microtopographic features, raised hummocks (98\%) had greater organic content than the depressed hollows (92\%). The hollows also had a greater water content than the hummocks (hollow $=9.9 \mathrm{~g} \mathrm{H}_{2} \mathrm{O}$ g-soil ${ }^{-1}$, hummock $=7.1 \mathrm{~g} \mathrm{H}_{2} \mathrm{O}$ g-soil ${ }^{-1}$ ). The $\mathrm{pH}$ of the hummocks (2.99) and hollows (2.98) in the S1 and S2-bog sites were comparable, as well as the slightly more circumneutral pH conditions of S3-fen hummock (6.40) and hollow (6.19). The gravimetric water content was slightly greater in the hummock $\left(8.99 \mathrm{~g} \mathrm{H}_{2} \mathrm{O}\right.$ g-soil $\left.{ }^{-1}\right)$ than the hollow (water content $=8.26 \mathrm{~g} \mathrm{H}_{2} \mathrm{O}$ g-soil ${ }^{-1}$ ). There was also lower organic content in the fen hummock feature $(81 \%)$ compared to the hollow feature $(86 \%)$.

Soils from the Site 3 fen had the overall average highest concentration of total extracted iron $\left(3,412 \pm 1,318 \mu \mathrm{g} \mathrm{g}_{\text {-soil }}{ }^{-1}\right)$ compared to the S1-bog $\left(147 \pm 62 \mu \mathrm{g}\right.$ g-soil $\left.^{-1}\right)$ and S2-bog $(262 \pm$ $130 \mu \mathrm{g} \mathrm{g-soil}{ }^{-1}$ ) (Table 12, Figure 18). S1 and S2-bogs exhibited higher concentrations of exchangeable Fe (average $=40 \pm 3.05 \mu \mathrm{g}$ g-soil $\left.{ }^{-1}\right)$ relative to the $\mathrm{S} 3$ fen $\left(<0.69 \mu \mathrm{g}\right.$ g-soil $\left.{ }^{-1}\right)$ (Figure 19). The largest pool of extracted iron within the bogs was crystalline iron oxides $(479 \pm$ $\left.267 \mu \mathrm{g} \mathrm{g}^{- \text {soil }^{-1}}, 47 \%\right)$, followed closely by organic-bound iron $\left(377 \pm 52 \mu \mathrm{g}\right.$ g-soil $\left.{ }^{-1}, 37 \%\right)$. S3fen contained higher concentrations of poorly crystalline Fe $\left(7,623 \pm 4,467 \mu \mathrm{g} \mathrm{g}_{\text {-soil }}{ }^{-1}\right)$, crystalline Fe $\left(3,946 \pm 1,115 \mu \mathrm{g} \mathrm{g}_{\text {-soil }}{ }^{-1}\right)$, and organic bound Fe $\left(2,033 \pm 581 \mu \mathrm{g} \mathrm{g}_{\text {-soil }}{ }^{-1}\right)$ than the bogs, with poorly crystalline Fe constituting the greatest proportion of extracted $\mathrm{Fe}(56 \%)$.

Average PSI in the S3 fen soils $(50 \pm 9.4)$ was higher than in $\mathrm{S} 1$ and $\mathrm{S} 2$ bog soils (avg 8.9 \pm 4.1 ) (Figure 20). Within S1 and S2-bogs, the hollow features exhibited a greater PSI (16 \pm 0.36) than the hummocks $(1.98 \pm 1.8)$. The PSI has an opposite trend at S3 where the hummocks $(59 \pm 15)$ had a greater PSI than the hollows $(40 \pm 7.8)$. 
Overall, the soils at the Site 3 fen exhibited more circumneutral pH, greater PSI, and larger pool of total iron concentrations, including organic-bound, poorly crystalline, and crystalline oxides, than the bogs. The S1 and S2 bog soils were more acidic, had lower PSI, and had higher concentrations of exchangeable Fe.

\subsection{Site comparison}

Overall, averaged from the four study sites, poorly-crystalline iron oxides made up the largest extracted pool of iron at $49 \%$ of total extracted iron (Figure 21). Organic-bound iron $(23 \%)$ and crystalline iron oxides (21\%) were the second and third largest pools of extracted iron, respectively. Soils from the Barrow Environmental Observatory (BEO) and the Alaskan Peatland Experiment (APEX) contained high proportions of organic-bound Fe and poorlycrystalline iron (Figure 22). Soils from Toolik Lake Field Station (TFS) and Marcell Experiment Forest contained greater proportions of $\mathrm{Fe}$ in poorly crystalline and crystalline oxides than in organic-bound Fe.

Summary outputs for linear regression statistics can be found in Appendix 2. Significant correlations $(\mathrm{p}<0.05)$ were observed between $\mathrm{pH}$ and organic-bound $\mathrm{Fe}\left(\mathrm{R}^{2}=0.21, \mathrm{p}=<0.001\right)$, poorly crystalline $\mathrm{Fe}\left(\mathrm{R}^{2}=0.47, \mathrm{p}=<0.001\right)$, crystalline Fe oxides $\left(\mathrm{R}^{2}=0.35, \mathrm{p}=<0.001\right)$, and magnetite $\left(\mathrm{R}^{2}=0.46, \mathrm{p}=<0.001\right)$. There was no significant correlation $(\mathrm{p}>0.05)$ between $\mathrm{pH}$ and exchangeable Fe.

There was a positive correlation between phosphate sorption index and $\mathrm{pH}\left(\mathrm{R}^{2}=0.23, \mathrm{p}\right.$ $=0.00013)$, where as $\mathrm{pH}$ increased, so did the ability for soils to sorb phosphate. There were also positive correlations between PSI and total iron extracted $\left(R^{2}=0.42, p=<0.001\right)$, organic bound $\mathrm{Fe}\left(\mathrm{R}^{2}=0.21 ; \mathrm{p}=<0.001\right)$, poorly crystalline $\mathrm{Fe}\left(\mathrm{R}^{2}=0.49 ; \mathrm{p}=\mathrm{p}<0.001\right)$, and crystalline $\mathrm{Fe}\left(\mathrm{R}^{2}\right.$ $=0.14, \mathrm{p}=0.003)$ from across all sites (Figure 22). Exchangeable iron also unexpectedly had a 
significant positive correlation with PSI $\left(\mathrm{R}^{2}=0.19, \mathrm{p}=<0.001\right)$, though not as strongly correlated as the previously mentioned. No correlations between PSI and magnetite Fe were observed $(\mathrm{p}>0.05)$.

\section{Discussion}

In this study, we examined geochemical properties of soils obtained from arctic tundra (Barrow Environmental Observatory, Toolik Field Station) and boreal (Alaskan Peatland Experiment, Marcell Experimental Forest) ecosystems. Within the study sites soils, phosphate sorption indices increased with increasing concentrations of total extracted iron. Furthermore, the dominant pools of poorly crystalline iron, and crystalline iron also showed a positive correlation with phosphate sorption capacity. The greatest coefficient of determination is represented by poorly-crystalline oxides $\left(\mathrm{R}^{2}=0.49\right)$.

Differences in Fe geochemistry, and thus phosphate sorption indices, were largely explained by differences in topography and water transport. Topographic lows of each study site exhibited the highest concentrations of poorly crystalline iron oxides and the largest ability to sorb phosphate. Poorly crystalline iron oxides accumulate in low-lying areas as the direct result of environmental $\mathrm{pH}$ and hydrological regimes. Fe oxides accumulate above the water table, which is near the soil surface in low-lying areas. Fe oxide precipitation is also more favorable under circumneutral conditions that exist in low-lying areas than in acidic conditions that were present in upland soils. The accumulation of Fe oxides, and particularly poorly crystalline Fe oxides, in turn increased the ability of soils to sorb phosphate. Soils in topographic high areas were more acidic and Fe-poor and had low capacity to bind phosphate.

\subsection{Iron-oxide accumulation at biogeochemical reactive boundaries}


Surface microtopography drives subsurface water flow patterns that transport redox sensitive solutes to regional hotspots (Frei et al., 2012). Hotspots are defined as areas that show disproportionally high reaction rates relative to the surrounding areas, or zones of higher reactivity (Jacks and Norrstrom, 2004; McClain et al. 2003; Morris and Waddington, 2011). These hot spots are linked to the transport, transformation, and accumulation of biogeochemical constituents, allowing for distribution throughout peat-forming wetlands. These subsurface flow patterns tend to migrate upward into zones of upwelling, creating saturated collection points in low-lying areas.

At Toolik Field Station, the highest points of the topographic sequence were represented by heath soils and tussock tundra with wet sedge soils representing the low-lying collection point, or potentially a site of peak biogeochemical reaction rates. The relatively saturated wet sedge soils, which were situated in a topographic low with the water table at the soil surface, had a significantly higher $\mathrm{pH}$, representing more circumneutral conditions, than the elevated tussock tundra and heath sites. Tussock tundra had the highest overall organic-content by over $30 \%$, which can account for the overall greater concentration of organic-bound Fe. As stated previously, not only did the $\mathrm{pH}$ conditions differ between sample locations at Toolik Lake Field Station, but so did the overall total iron concentrations. The 20 -fold increase in total Fe from the tussock tundra and heath to the wet sedge soils can be accounted for by these topographic lows acting as geochemical collection spots and by the circumneutral $\mathrm{pH}$ conditions that favored the formation of Fe-oxides both crystalline and poorly crystalline at the redox boundary. The formation of these iron oxides contributed to the more predominate role of wet sedge soils in nutrient sequestration than the organic-rich soils located in the tussock tundra. 
Iron accumulation in soils at the Marcell Experimental Forest also demonstrated similar effects of topography and hydrology attributed to mineral rich geochemical pools. Similar to the TFS wet sedge soil characteristic and the BEO low-centered polygon soils which acted as the topographic lows receiving sub-surface water, the Site 3 fen at MEF receives water from regional groundwater flow. Inputs from groundwater and runoff may impact geochemical properties by introducing high concentrations of dissolved solutes, creating a geochemical hotspot where groundwater mixes with surface water. Groundwater also tends to have higher $\mathrm{pH}$ and buffering capacity than rain water due to interaction with subsurface carbonates, influencing $\mathrm{pH}$ towards circumneutral conditions. This promotes the precipitation of iron oxides and the accumulation of these iron oxides at the geochemical boundary, or at the water table boundary. Iron oxide accumulation can be accountable for the greater phosphate sorption index at the Site 3 fen compared to the Site 1 and Site 2 bogs. Site 1 and Site 2 bog systems are characterized by dominantly precipitation inputs and by the presence of Sphagnum moss. Sphagnum moss exude organic acids that further decrease $\mathrm{pH}$ towards acidic conditions (Verry et al., 2011). We observe low soil $\mathrm{pH}$ and high concentrations of exchangeable iron in Sites 1 and 2 versus Site 3. Acidic conditions may promote soluble iron to complex with organic matter or remain in soil solution, versus precipitate as iron oxides.

In contrast to TFS and MEF, soils at BEO and APEX contained high concentrations of organic-bound Fe across all landscape features. At BEO, sites with the largest ability to sequester phosphate (organic horizons in low-centered polygons) were dominated by the presence of organic-bound Fe rather than presence of iron oxides, or a combination of the two. As well as accumulating iron oxides at redox boundaries, organic rich soils may be associated with tertiary complexes between organic matter, Fe ions (represented by Fe Org in the sequential extraction 
fraction), and inorganic bioavailable phosphate (Kizewski et al 2010). Gerke (2010) discussed the potential that the phosphate sorption capacity of humic-metal complexes is higher than for purely inorganic crystalline and poorly crystalline oxides, further supporting the importance of tertiary complexes while describing organic rich systems. These organic-Fe-P complexes may limit the concentration of inorganic $\mathrm{P}$ bioavailable for vegetation uptake, similar to effects of sorption by iron oxides. In low-lying, saturated accumulation zones, the increase in organic bound Fe accumulation can be associated with the increase in organic accumulation. In BEO soils, it is possible that organic-Fe complexes increase the concentration of additional adsorption sites for inorganic phosphate, in turn increasing the PSI; however, this trend was not necessarily observed at other sites. Similar to the organic-rich soils at BEO, the peat soils at APEX were acidic and contained high concentrations of organic matter, supporting higher concentrations of organic-bound Fe. At APEX, there was also the potential for Organic-Fe-P complexes to sequester nutrients rather than iron oxides; however, specific associations between these elements could not be determined in this study.

As previously discussed, subsurface flow paths control biogeochemical boundary conditions that host redox reactions. With the potential of increased soil saturation and water flow in Northern peatlands resulting from the thawing of previously frozen soils, there is a potential to increase the transport and accumulation of redox sensitive constituents, i.e. iron, at these low-lying saturation zones or redox boundaries. At these boundaries, the introduction of redox sensitive iron causes an accumulation of iron-oxide minerals, leading to increased $\mathrm{P}$ retention.

\subsection{Future implications}


Although this study focused on portraying a geochemical proxy along a latitudinal gradient as a factor of potential global climate change, the results and findings can be applied to further studies in Northern peatland nutrient limited ecosystems. Specifically, the overall trend of saturated soils accumulating organic and oxide minerals further acting as a biogeochemical sink for nutrients can be applied to any region experiencing an increase in saturation or areas experiencing overall gradient shifts. In order to predict future nutrient cycling in Northern peatlands impacted by climate change, it is necessary to understand the impact of water tables and redox conditions on nutrient mobility.

Along with the predicted increase in global mean temperature, there is a predicted increase in thawing of previously frozen soils which will have the potential to either increase surface soil saturation from water accumulation or decrease soil saturation as a result of lowering water tables and increasing oxidation. Either process would lead to a shift in nutrient cycling and redox reactions, differing from the processes apparent at present time.

With the scenario of increased surface saturation, the apparent water table rise or accumulation zones of topographic lows can act as geochemical redox boundaries and hotspots, increasing the potential for redox sensitive constituents to react. On the other hand, widespread soil drainage will increase oxidation and encourage the precipitation of iron oxyhydroxide minerals. Abiotic features (i.e. iron (oxyhydr)oxides) may effectively compete with biological processes for bioavailable phosphate, controlling the bioavailability of $\mathrm{P}$ through these interactions. As phosphorus is a limited nutrient in northern latitude ecosystems, the potential shift of ecology due to predicted climate change could increase the demand for this already limited nutrient.

\section{Conclusion}


This project provides foundational understanding of $\mathrm{Fe}$ geochemistry and $\mathrm{Fe}-\mathrm{P}$ associations in peatland organic and mineral soils across a large geographic gradient, spanning from the southern point of a boreal forest in Minnesota to the northernmost point of the United States in the arctic tundra of Alaska. Shifts in water table position and hydrologic fluxes driven by climate change are likely to impact the development and nutrient cycling of developing Northern peatlands. With global circulation models predicting air temperature to increase up to $5^{\circ} \mathrm{C}$ in the next half century (Osterkamp and Jorgenson, 2009; Maxwell, 1992), localized thawing and ice wedge thawing is expected. Thawing of permafrost-underlain regions along with landscape topography will control local hydrological processes, resulting in either an overall drying of surface soils by lowering the water table, or saturating surface soils by raising the water table. Changes or shifts in oxygen and moisture conditions control the oxidation-reduction (redox) conditions and biogeochemistry of soil constituents such as phosphorus $(\mathrm{P})$ and iron $(\mathrm{Fe})$. Our objective in this study was to characterize the geochemical forms of iron that present in organic and mineral soils located in topographic highs and lows of northern peatlands. Additionally, we evaluated the potential for these soils to bind phosphate as a predictor of bioavailable phosphorus limitation.

In poorly-drained, reduced soils, $\mathrm{Fe}(\mathrm{II})$ that is mobilized from mineral weathering in deep anoxic soils is extremely soluble and easily redistributed. Fe(II) may be leached from the soil or migrate upwards in the soil profile towards oxic conditions near the soil surface, precipitating as poorly crystalline ferrihydrite (Zak et al. 2004; Riedel et al. 2012; Herndon et al. 2015a). In welldrained oxic soils, $\mathrm{Fe}$ (III) may precipitate out forming Fe(III)-(oxy)hydroxide minerals (Herndon et al. 2017; Schwertmann, 2008). These Fe(III)-(oxy)hydroxides can strongly adsorb inorganic phosphate from solution. Fe(III) may also be complexed by organic matter in the organic horizon 
(Herndon et al. 2015a) and lead to the formation of Fe-P-organic tertiary complexes (Kizewski et al 2010). Based on the results of this study, I conclude there is a direct association with the precipitation of iron (oxyhydr)oxide minerals and an increase for the potential of these soils to sorb inorganic phosphate (PSI), potentially limiting P availability to plants for uptake into biomass. The precipitation and presence of iron oxide minerals may be collocated with redox boundaries, creating accumulation zones in locations of topographic low-lying regions. Additional aqueous geochemical parameters such as $\mathrm{pH}$ and total Fe concentrations, which were related to the source of water, also contributed to the formation of iron oxides. The alteration of natural hydrology conditions because of global climate change directly affects nutrient availability, nutrient cycling, precipitation or dissolution of anions, and organic decomposition. The effects of nutrient availability as a function of oxide mineral formation has ramifications for continued research in proper ecosystem functioning, biogeochemical cycling, and climate change. 


\section{References}

Amacher, M. C., Henderson, R. E., Breithaupt, M. D., Seale, C. L., \& LaBauve, J. M. (1990). Unbuffered and buffered salt methods for exchangeable cations and effective cationexchange capacity. Soil Science Society of America Journal, 54(4), 1036-1042. http://doi.org/10.2136/sssaj1990.03615995005400040018x

Bache, B. W., \& Williams, E. G. (1971). A Phosphate Sorption Index for Soils. Journal of Soil Science, 22(3), 289-301. https://doi.org/10.1111/j.1365-2389.1971.tb01617.x

Baldwin, D. S. (1996). Effects of exposure to air and subsequent drying on the phosphate sorption characteristics of sediments from a eutrophic reservoir. Limnology and Oceanography, 41:1725-1732.

Bekryaev, R. V., Polyakov, I. V., \& Alexeev, V. A. (2010). Role of polar amplification in longterm surface air temperature variations and modern Arctic warming. Journal of Climate, 23(14), 3888-3906.

Boelter, D. H. (1966). Important Physical Properties of Peat Materials. Proceedings, Third International Peat Congress, (Bay), 150-154.

Boelter, D., \& Verry, E. (1977). Peatland and water in the northern Lake States. USDA For. Serv. Gen. Tech. Rep. NC-31, 22.

Borggaard, O. K. (1983). The influence of iron oxides on phosphate adsorption by soil. Journal of Soil Science, 34, 333-341. http://doi.org/10.1111/j.1365-2389.1983.tb01039.x

Brown. R. I. E. (1967). Permafrost in Canada. Map 126JA. Ottawa: Geological Survey of Canadmational Research Council of Canada.

Chapin, F. S., Barsdate, R. J., \& Barel, D. (1978). Phosphorus Cycling in Alaskan Coastal Tundra - Hypothesis for the Regulation of Nutrient Cycling. Oikos, 31(2), 189-199. http://doi.org/10.2307/3543562

Christensen, T. R. (2004). Thawing sub-arctic permafrost: Effects on vegetation and methane emissions. Geophysical Research Letters, 31(4), L04501.

http://doi.org/10.1029/2003GL018680

EDCT [Environmental Data Center Team] (2017). Meteorological monitoring program at Toolik, Alaska. Toolik Field Station, Institute of Arctic Biology, University of Alaska, Fairbanks, AK.

Emerson, D., Scott, J. J., Benes, J., \& Bowden, W.B. (2015). Microbial iron oxidation in the Arctic tundra and the implications for biogeochemical cycling. Applied and Environmental Microbiology, 81(23), 8066-8075. http://doi.org/10.1128/AEM.02832-15 
Frei, S., Knorr, K. H., Peiffer, S., \& Fleckenstein, J. H. (2012). Surface micro-topography causes hot spots of biogeochemical activity in wetland systems: A virtual modeling experiment. Journal of Geophysical Research: Biogeosciences, 117(4), 1-18. http://doi.org/10.1029/2012JG002012

Froelich, P. N. (1988). Kinetic control of dissolved phosphate in natural rivers and estuaries: A primer on the phosphate buffer mechanism. Limnology and Oceanography, 33(4), 649-668.

Gardner, W. H. (1986). Water content. In Methods of soil analysis, Part 1. Physical and Mineralogical Methods.

Gerke, J. (2010). Humic (Organic Matter)-Al(Fe)-Phosphate Complexes. Soil Science. https://doi.org/10.1097/SS.0b013e3181f1b4dd

Giblin, A.E., Nadelhoffer, K. J., Shaver, G. R., Laundre, J. A., \& McKerrow, A. J. (1991). Biogeochemical diversity along a riverside toposequence in arctic Alaska. Ecological Monographs, 61(4), 415-435. http://doi.org/10.2307/2937049

Griffin, G.F., (1982). A rapid method of estimating the phosphorous sorption capacity of soils. Storrs Agricultural Experiment Station, 21.

Hyland, Jeffrey \& Balthis, L \& Karakassis, Ioannis \& Magni, Paolo \& Petrov, Alexei \& Shine, J \& Vestergaard, Ole \& Warwick, Richard. (2005). Organic carbon of sediments as an indicator of stress in the marine benthos. Marine Ecology Progress Series, 295. 91-103. $10.3354 /$ meps 295091.

Herndon, E. M., Yang, Z., Bargar, J., Janot, N., Regier, T. Z., Graham, D. E., Gu, B., and Liang, L. (2015a) Geochemical drivers of organic matter decomposition in arctic tundra soils. Biogeochemistry, 126(3), 397-414. doi.org/10.1007/s10533-015-0165-5

Herndon, E., Albashaireh, A., Singer, D., Roy Chowdhury, T., Gu, B., \& Graham, D. (2017). Influence of iron redox cycling on organo-mineral associations in Arctic tundra soil. Geochimica et Cosmochimica Acta, 207, 210-231. http://doi.org/10.1016/j.gca.2017.02.034

Hill, D.E. \& Tedrow, J.C.F.. (1961). Weathering and soil formation in the Arctic environment. American Journal of Science, 259, 84-101.

Hinkel, K. M., Nelson, F. E., Klene, A. E., \& Bell, J. H. (2003). The urban heat island in winter at Barrow, Alaska. International Journal of Climatology, 23(15), 1889-1905. https://doi.org/10.1002/joc.971

Hinzman, L. D., Bettez, N. D., Bolton, W. R., Chapin, F. S., Dyurgerov, M. B., Fastie, C. L., Yoshikawa, K. (2005). Evidence and implications of recent climate change in Northern Alaska and other Arctic regions. Climatic Change, 72(3), 251-298. http://doi.org/10.1007/s10584-005-5352-2 
Hinzman, L. D., Deal, C. J., Mcguire, A. D., Mernild, S. H., Polyakov, V., Walsh, J. E., ... Mcguire, A. D. (2018). Trajectory of the Arctic as an integrated system Published by: Wiley on behalf of the Ecological Society of America Stable URL :

http://www.jstor.org/stable/23596892 Trajectory of the Arctic as an integr, 23(8), 18371868.

Holland, M. M., \& Bitz, C. M. (2003). Polar amplification of climate change in coupled models. Climate Dynamics, 21(3-4), 221-232.

Hubbard, S. S., Gangodagamage, C., Dafflon, B., Wainwright, H., Peterson, J., Gusmeroli, A., \& Wullschleger, S. D. (2013). Quantifying and relating land-surface and subsurface variability in permafrost environments using LiDAR and surface geophysical datasets. Hydrogeology Journal, 21(1), 149-169.

Jacks, G., \& Norrström, A. C. (2004). Hydrochemistry and hydrology of forest riparian wetlands. Forest Ecology and Management, 196(2-3), 187-197. http://doi.org/10.1016/j.foreco.2004.01.055

Johnston, C. A. (1991), Sediment and nutrient retention by freshwater wet- lands: Effects on surface water quality, Crit. Rev. Environ. Sci. Technol., 21(5-6), 491-565. doi:10.1080/10643389109388425.

Jordan, C. F., \& Kline, J. R. (1972). Mineral Cycling: Some Basic Concepts and Their Application in a Tropical Rain Forest. Annual Review of Ecology and Systematics, 3(1), 33 50. http://doi.org/10.1146/annurev.es.03.110172.000341

Jorgenson, M. T., Shur, Y. L., and Pullman, E. R. (2006) Abrupt increase in permafrost degradation in Arctic Alaska. Geophys. Res. Lett., 33(2), 2-5. doi.org/10.1029/2005GL024960

Kane, E. S., Turetsky, M. R., Harden, J. W., McGuire, A. D., \& Waddington, J. M. (2010). Seasonal ice and hydrologic controls on dissolved organic carbon and nitrogen concentrations in a boreal-rich fen. Journal of Geophysical Research: Biogeosciences, 115(4), 1-15. http://doi.org/10.1029/2010JG001366

Kinsman-Costello, L. E., O’Brien, J., \& Hamilton, S. K. (2014). Re-flooding a Historically Drained Wetland Leads to Rapid Sediment Phosphorus Release. Ecosystems, 17(4), 641656. https://doi.org/10.1007/s10021-014-9748-6

Kizewski, F. R., Boyle, P., Hesterberg, D., \& Martin, J. D. (2010). Mixed Anion ( Phosphate / Oxalate ) Bonding to Iron ( III ) Materials, 155(Iii), 2301-2308.

Lipson, D. A., Jha, M., Raab, T. K., \& Oechel, W. C. (2010) Reduction of iron (III) and humic substances plays a major role in anaerobic respiration in an Arctic peat soil. Journal of Geophysical Research: Biogeosciences, 115(4), 1-13. doi.org/10.1029/2009JG001147 
Lipson, D. A., Zona, D., Raab, T. K., Bozzolo, F., Mauritz, M., \& Oechel, W. C. (2012). Watertable height and microtopography control biogeochemical cycling in an Arctic coastal tundra ecosystem. Biogeosciences, 9(1), 577-591. http://doi.org/10.5194/bg-9-577-2012

Lipson, D. A., Raab, T. K., Goria, D., and Zlamal, J. E. (2013). The contribution of Fe(III) and humic acid reduction to ecosystem respiration in drained thaw lake basins of the Arctic Coastal Plain. Global Biogeochemical Cycles, 27(2), 399-409. http://doi.org/10.1002/gbc.20038

Lovley, D. R., Stolz, J. F., Nord, G. L., \& Phillips, E. J. P. (1987) Anaerobic production of magnetite by a dissimilatory iron-reducing microorganism. Nature, 330(6145), 252-254.

Lovley, D.R. (1993) Dissimilatory metal reduction. Annual Review of Microbiology, 47, 263290. https://doi.org/10.1146/annurev.mi.47.100193.001403

Maxwell, B., 1992, Arctic climate: potential for change under global warming, in Chapin, F.S., III, Jeffries, R.L., Reynolds, J.F., Shaver, G.R., and Svoboda, J., eds., Arctic Ecosystems in a Changing Climate: San Diego, Academic Press, p. 11-34.

McClain, M. E., Boyer, E. W., Dent, C. L., Gergel, S. E., Grimm, N. B., Groffman, P. M., \& Pinay, G. (2003). Biogeochemical hot spots and hot moments at the interface of terrestrial and aquatic ecosystems. Ecosystems, 6(4), 301-312. http://doi.org/10.1007/s10021-0030161-9

McLaughlin, J. R., J. C. Ryden, \& J. K. Syers. (1981). Sorption of inorganic phosphate by ironand aluminum-containing components. Journal of Soil Science, 32, 365- 377.

Morris, P. J., \& Waddington, J. M. (2011). Groundwater residence time distributions in peatlands: Implications for peat decomposition and accumulation. Water Resources Research, 47(2), 1-12. https://doi.org/10.1029/2010WR009492

Nagarajah, S., A. M. Posner \& J.P. Quirk, (1970). Competitive adsorption of phosphate with polygalacturonate and other organic anions on kaolinite and oxide surfaces. Nature, 228, 83-84.

Newman, B. D., Throckmorton, H. M., Graham, D. E., Gu, B., Hubbard, S. S., Liang, L. Wullschleger, S. D. (2015) Microtopographic and depth controls on active layer chemistry in Arctic polygonal ground. Geophysical Research Letters, 42(6), 1808-1817.

Nichols, D. S., \& Brown, J. M. (1980). [1] Evaporation From a Sphagnum Moss Surface *1. Journal of Hydrology, 48, 289-302. http://doi.org/10.1016/0022-1694(80)90121-3

Odum, E. P. (1969). The strategy of ecosystem development. Science. https://doi.org/10.1126/science.164.3877.262 
Oechel, W. C., Hastings, S. J., Vourlrtis, G., Jenkins, M., Riechers, G., \& Grulke, N. (1993). Recent change of Arctic tundra ecosystems from a net carbon dioxide sink to a source. Nature, 361(6412), 520-523. https://doi.org/10.1038/361520a0

Osterkamp.T. E., L. Viereck, Y. Shur, M. 1'. Jorgenson, C. Racine, A. Doyle, and R. D. Boone (2000), Observations of thermokarsr and its impact on boreal forests in Alaska, USA, Arct, Antarct. Alp. Res., 32, 303-315.

Osterkamp, T.E., \& Jorgenson, M.T., (2009). Permafrost conditions and processes, in Young, R., and Norby, L., Geological Monitoring: Boulder, Colorado, Geological Society of America, p. 205-227 doi: 10.1130/2009.monitoring(09)

Osterkamp, T. E., \& Romanovsky, V.E. (1999) Evidence for warming and thawing of discontinuous permafrost in Alaska. Permafrost Periglac., 10(1), 17-37.

Poff, N. L., M. M. Brinson, and J. W. Day, Jr. (2002). Aquatic ecosystems \& global climate change: Potential impacts on inland freshwater and coastal wetland ecosystems in the United States. Pew Center on Global Climate Change.

Poulton, S. W., \& Canfield, D.E. (2005). Development of a sequential extraction procedure for iron: implications for iron partitioning in continentally derived particulates. Chemical Geology, 214(3-4), 209-221. http://doi.org/10.1016/j.chemgeo.2004.09.003

Rayment, G. E \& Higginson, F. R., (1992). Australian laboratory handbook of soil and water chemical methods. Inkata Press, Port Melbourne.

Richardson, C.J. (1985) Mechanisms controlling phosphorus retention capacity in freshwater wetlands. Science, 228, 1424-1427.

Riedel, T., Biester, H., and Dittmar, T. (2012) Molecular fractionation of dissolved organic matter with metal salts. Environmental Science Technology, 46(8), 4419-4426. doi.org/10.1021/es203901u

Roden, E. E., and Edmonds, J. (1997) Phosphate mobilization in iron-rich anaerobic sediments: microbial Fe (III) oxide reduction versus iron-sulfide formation. Archiv Für Hydrobiologie, 139(3), 347-378.

Ruttenberg, K. C. (2013). The Global Phosphorus Cycle. Treatise on Geochemistry: Second Edition, 10, 499-558. http://doi.org/10.1016/B978-0-08-095975-7.00813-5

Romanovsky, V. E., \& Osterkamp, T. E. (2000). Effects of unfrozen water on heat and mass transport processes in the active layer and permafrost. Permafrost and Periglacial Processes, 11, 219-239.

Roy Chowdhury, T., Herndon, E. M., Phelps, T. J., Elias, D. A., Gu, B., Liang, L., Wullschleger, S., and Graham, D. E. (2015). Stoichiometry and temperature sensitivity of methanogenesis 
and $\mathrm{CO} 2$ production from saturated polygonal tundra in Barrow, Alaska. Global Change Biology, 21(2), 722-737.

Schwertmann, U., (2008) Iron Oxides. In Encyclopedia of Soil Science (pp. 363-369) Springer Netherlands.

Schuur, E. A., McGuire, A. D., Schädel, C., Grosse, G., Harden, J. W., Hayes, D. J., ... \& Natali, S. M. (2015). Climate change and the permafrost carbon feedback. Nature, 520(7546), 171.

Sebestyen, S. D., Dorrance, C., Olson, D. M., Verry, E. S., Kolka, R. K., Elling, A. E., \& Kyllander, R. (2011). Long-Term Monitoring Sites and Trends at the Marcell Experimental Forest. In R. Kolka, S. Sebestyen, E. S. Verry, \& K. Brooks (Eds.), Peatland biogeochemistry and watershed hydrology at the Marcell Experimental Forest (pp. 15-71). CRC Press, Taylor Francis Group

Shen, J., Yuan, L., Zhang, J., Li, H., Bai, Z., Chen, X., Zhang, F. (2011). Phosphorus Dynamics: From Soil to Plant. Plant Physiology, 156(3), 997-1005. http://doi.org/10.1104/pp.111.175232

Siregar, A., Kleber, M., Mikutta, R., \& Jahn, R. (2005). Sodium hypochlorite oxidation reduces soil organic matter concentrations without affecting inorganic soil constituents. European Journal of Soil Science, 56(4), 481-490. http://doi.org/10.1111/j.1365-2389.2004.00680.x

Slomp, C. P., Van der Gaast, S. J., \& Van Raaphorst, W. (1996). Phosphorus binding by poorly crystalline iron oxides in North Sea sediments. Marine Chemistry, 52(1), 55-73. http://doi.org/10.1016/0304-4203(95)00078-X

Sparks, D.L. (1996). Methods of soil analysis. Part 3. Chemical methods. SSSA Book Ser. 5. SSSA, Madison, WI.

Sposito, G., (1990). The Chemistry of Soils. Oxford University Press, New York.

Tarnocai, C., Canadell, J. G., Schuur, E. A. G., Kuhry, P., Mazhitova, G., and Zimov, S. (2009). Soil organic carbon pools in the northern circumpolar permafrost region. Global Biogeochemical Cycles, 23(2), 1-11. http://doi.org/10.1029/2008GB003327

Tedrow, C.F. \& Brown, J. (1962). Soils of the Northern Brooks Range, Alaska: Weakening of the soil-forming potential at high arctic altitudes. Soil Science, 93, 254-261.

Tessier, a, Campbell, P. G. C., and Bisson, M. (1979). Sequential extraction procedure for the speciation of particulate trace metals. Analytical Chemistry, 51(7), 844-851. http://doi.org/10.1021/ac50043a017

Theis, T. L., and Singer, P. C. (1974) Complexation of Iron(II) by Organic Matter and Its Effect on Iron(II) Oxidation. Environ. Sci. Technol., 8(6), 569-573. doi.org/10.1021/es60091a008 
Thompson, A., Chadwick, O. A., Rancourt, D. G., and Chorover, J. (2006) Iron-oxide crystallinity increases during soil redox oscillations. Geochim. Cosmochim. Acta, 70(7), 1710-1727. doi.org/10.1016/j.gca.2005.12.005

Turetsky, M. R. (2004). Decomposition and organic matter quality in continental peatlands: The ghost of permafrost past. Ecosystems. https://doi.org/10.1007/s10021-004-0247-z

Turetsky, M. R., Treat, C. C., Waldrop, M. P., Waddington, J. M., Harden, J. W., and McGuire, A. D. (2008). Short-term response of methane fluxes and methanogen activity to water table and soil warming manipulations in an Alaskan peatland. Journal of Geophysical Research: Biogeosciences, 113(3). http://doi.org/10.1029/2007JG000496

Van Cleve, K., Viereck, L.A., Marion, G.M., (1993a). Introduction and overview of a study dealing with the role of salt-affected soils in primary succession on the Tanana River floodplain, interior Alaska. Canadian Journal of Forest Research, 23, 879-888.

Verry, E., Boelter, D., Paivanen, J., Nichols, D., Malterer, T., \& Gafni, A. (2011). Physical properties of organic soils. Peatland Biogeochemistry and Watershed Hydrology, (1959), $135-176$

Vincent, A. G., Sundqvist, M. K., Wardle, D. A., \& Giesler, R. (2014). Bioavailable soil phosphorus decreases with increasing elevation in a subarctic tundra landscape. PLoS ONE, 9(3), 1-11. http://doi.org/10.1371/journal.pone.0092942

Vitt, D.H., (2006). Functional characteristics and indicators of boreal peatlands. In Wieder, R.K., Vitt, D.K. (Eds.), Boreal Peatland Ecosystems. Springer-Verlag Berlin Heidelberg, New York, pp. 1-8.

Peter M. Vitousek; Stephen Porder; Benjamin Z. Houlton; Oliver A. Chadwick. In: Ecological Applications. 20(1):5-15; Ecological Society of America, 2010.

Walbridge M.R. and Struthers J.P. 1993. Phosphorus retention in non-tidal palustrine forested wetlands of the mid-Atlantic region. Wetlands 13: 84-94.

Wullschleger, S. D., Hinzman, L. D., and Wilson, C. J. (2011) Planning the next generation of Arctic Ecosystem Experiments. Eos, 92(17), 145. doi.org/10.1029/2011EO170006

Zak, D., Gelbrecht, J., and Steinberg, C. E. W. (2004) Phosphorus retention at the redox interface of peatlands adjacent to surface waters in Northeast Germany. Biogeochemistry, 70(3), 357-368. doi.org/10.1007/s10533-003-0895-7

Yoshikawa, K., and Hinzman, L. D. (2003) Shrinking thermokarst ponds and groundwater dynamics in discontinuous permafrost near Council, Alaska. Permafrost Periglac., 14(2), 151-160. doi.org/10.1002/ppp.451 
Zona, D., Lipson, D. A., Zulueta, R. C., Oberbauer, S.F., \& Oechel, W. C. (1992).

Microtopographic controls on ecosystem functioning in the Arctic Coastal Plain. Journal of Modern Optics, 34(1), Zona, 1992; 1401-1407.

http://doi.org/10.1016/j.celrep.2011.1011.1001.7. 


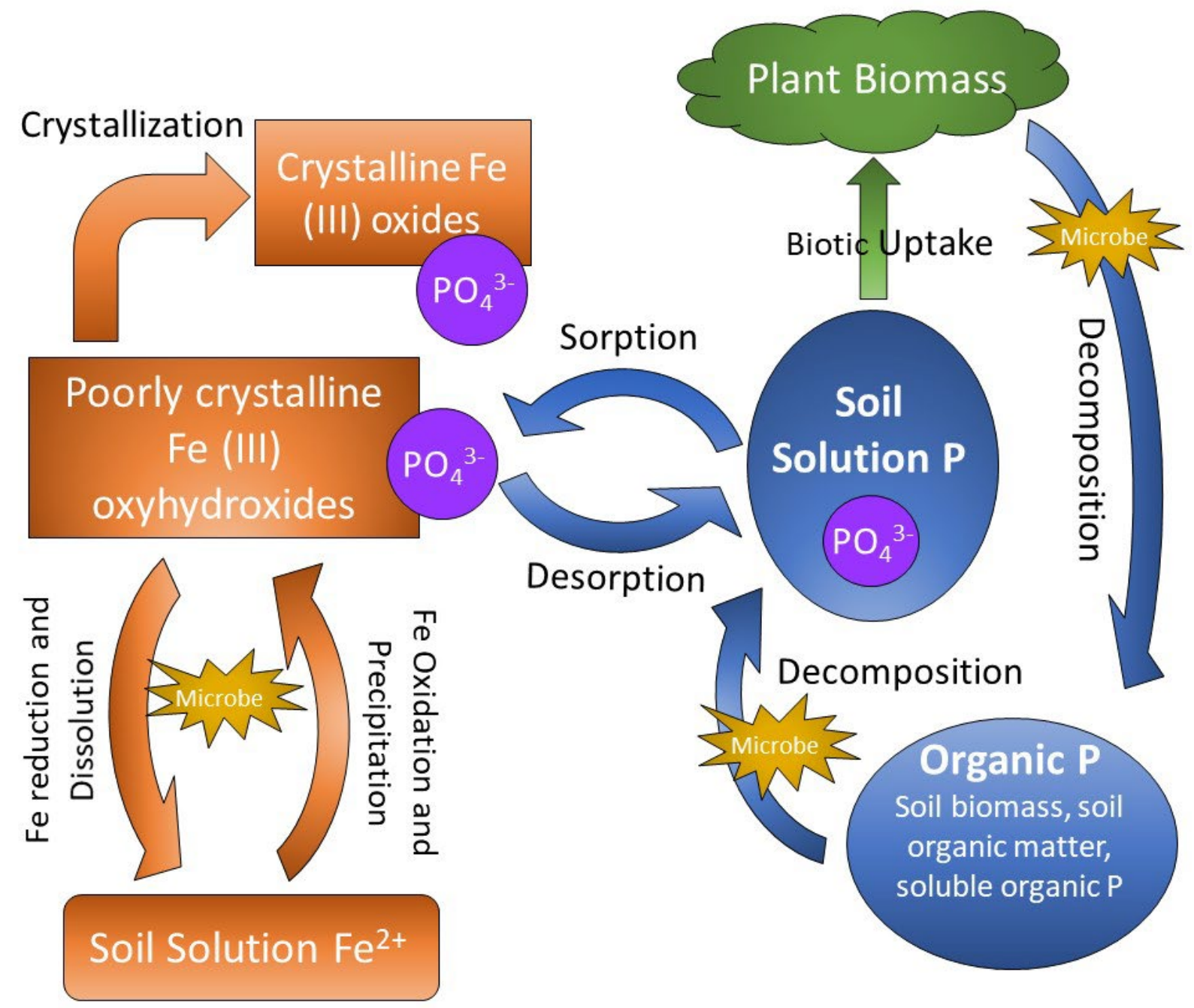

Figure 1: Conceptual model of Fe-P interactions in soils. Iron species are controlled primarily by redox conditions $\left(\mathrm{Fe}^{2+}\right.$ in soil solution $\longleftrightarrow \mathrm{Fe}$-oxide precipitates) while $\mathrm{P}$ species are controlled primarily by microbial activity (inorganic $\mathrm{P}$ in soil solution $\longleftrightarrow \longrightarrow$ organic $\mathrm{P}$ in biomass). Potential pathways for limitations of bioavailable phosphate (inorganic $\mathrm{P}$ in soil solution) include biotic uptake, microbial assimilation, and/or sorption onto Fe-oxides. 


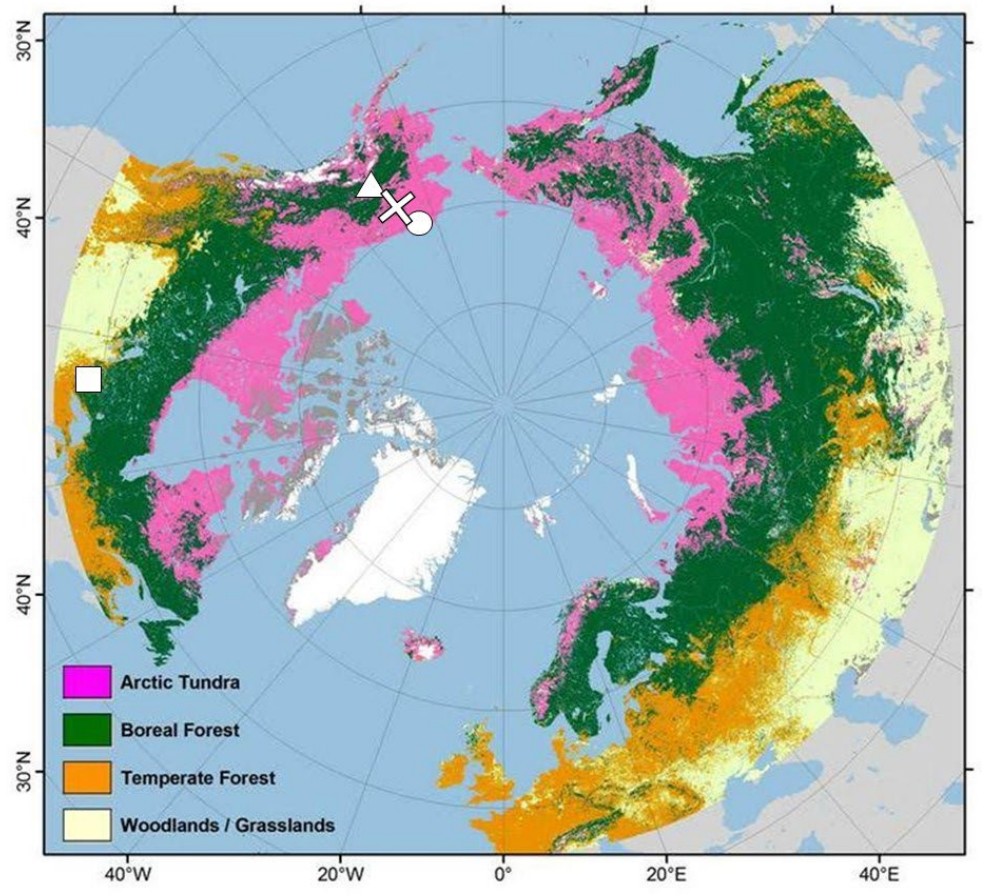

Figure 2: Locations of each site on a circumpolar map showing distribution of tundra and boreal ecotones in the arctic and subarctic regions. The sites include Barrow Environmental Observatory (circle), Toolik Field Station/Arctic LTER (X), Alaskan Peatland Experiment (triangle), and Marcell Experimental Forest (square) (photo: G. Nowacki lter.uaf.edu). 


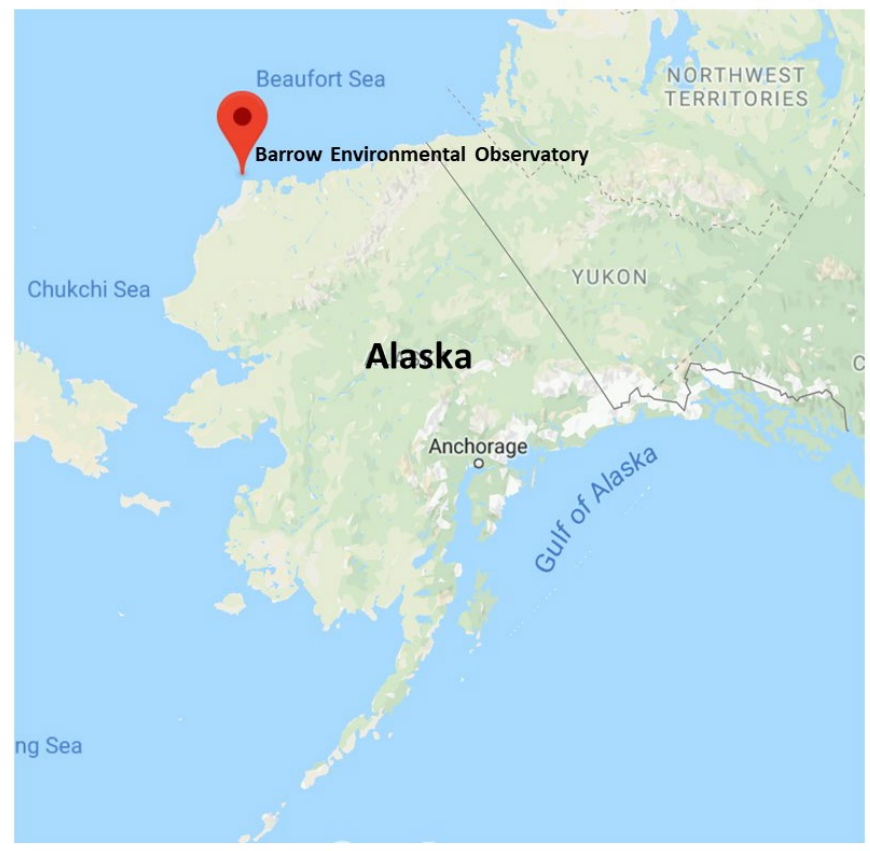

Figure 3: The Barrow Environmental Observatory (BEO) is located outside of Utqiagvik, AK on the Alaskan North Slope north of the Brooks Range Mountains (photo: Google Earth). 


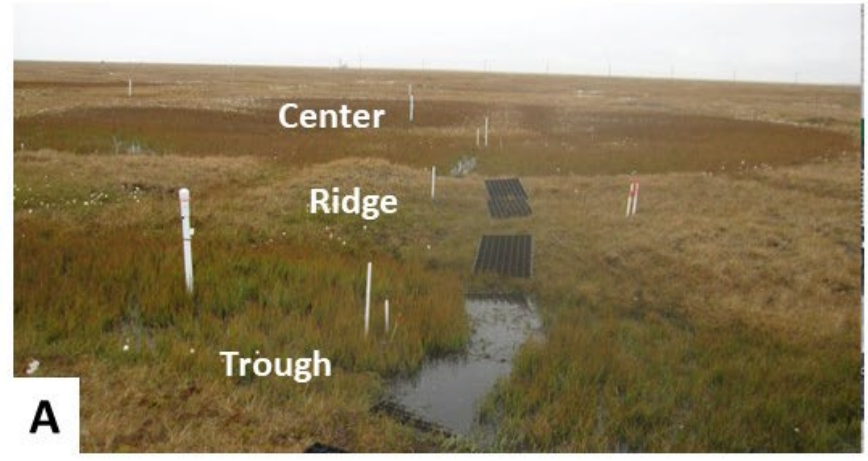

\section{Low-centered Polygon (LCP)}

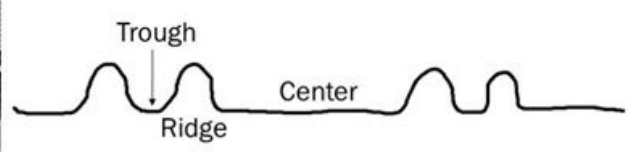

B

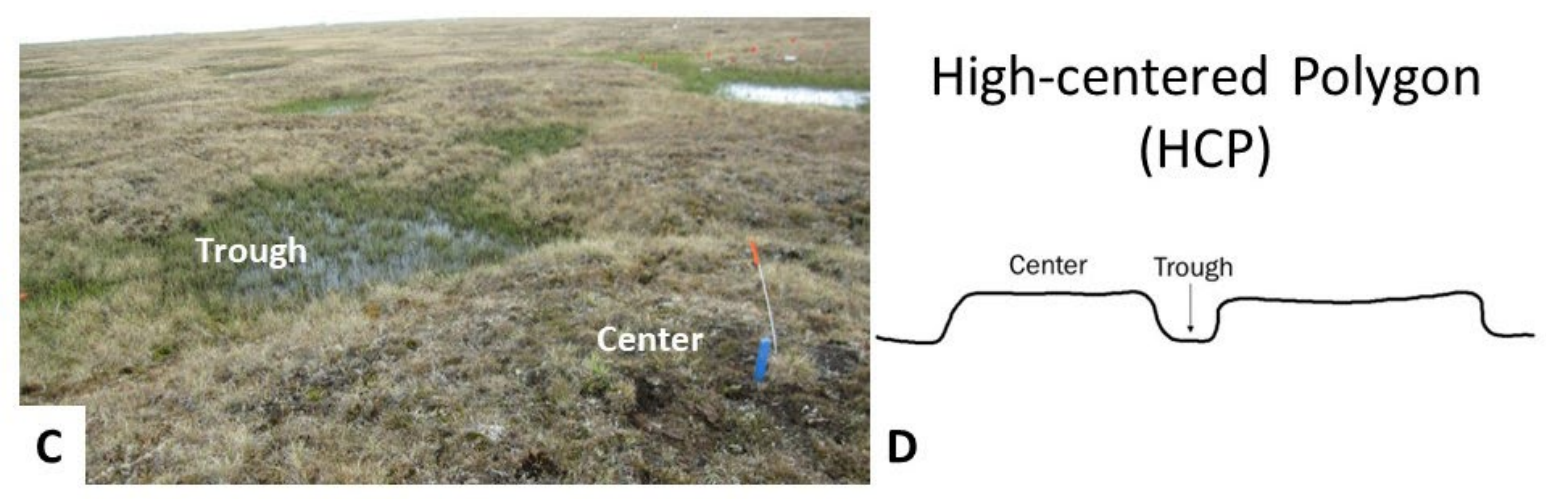

Figure 4: Photos were taken at Barrow Environmental Observatory, August 2013. A) Photo of Low-Centered Polygon (LCP) with Center, Ridge, and Trough positions represented. B) Crosssection diagram showing relative elevations. C) Photo of High-Centered Polygon with Center and Trough positions represented. D) Cross-section diagram showing relative elevations. This figure has been modified from Herndon et al. (2015). 


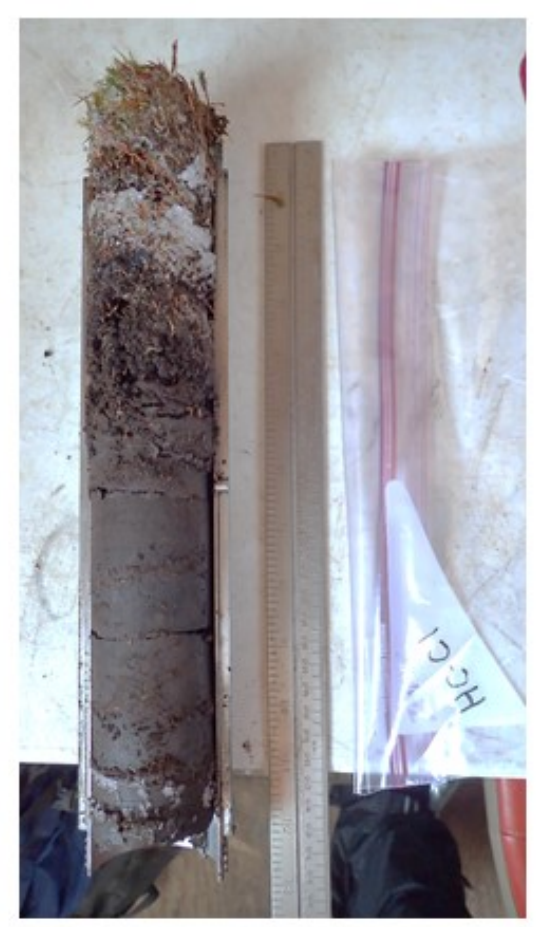

HCP-Center (1)

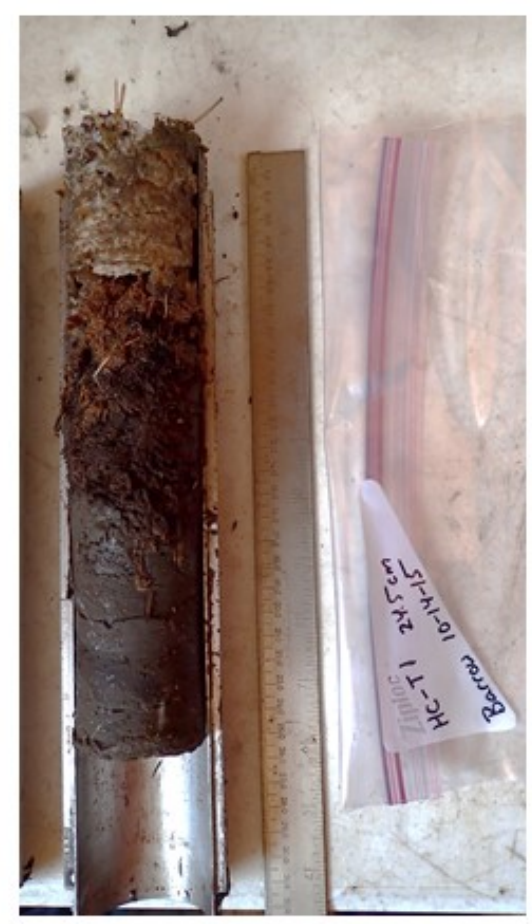

HCP-Trough (1)

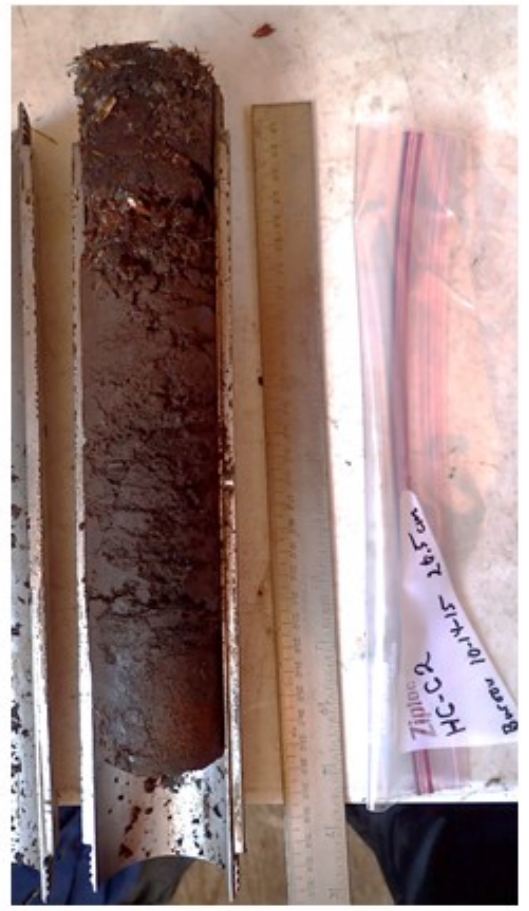

HCP-Center (2)

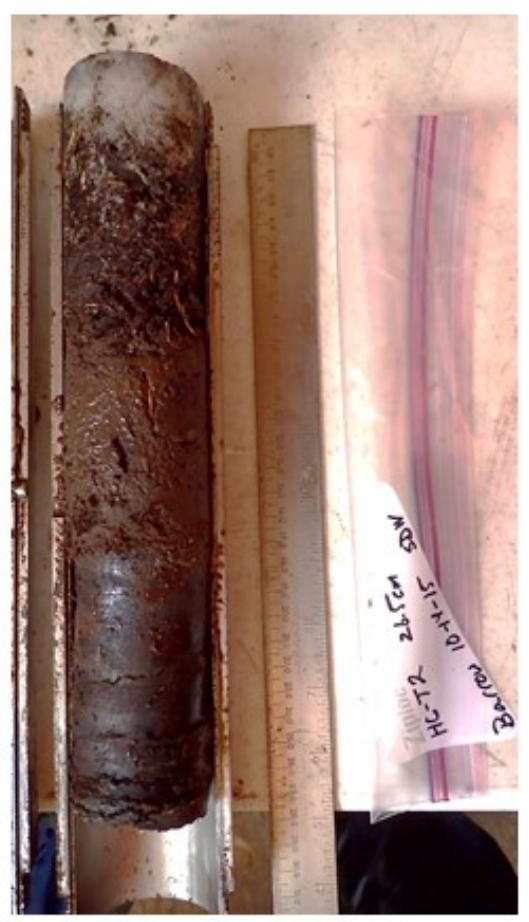

HCP-Trough (2)

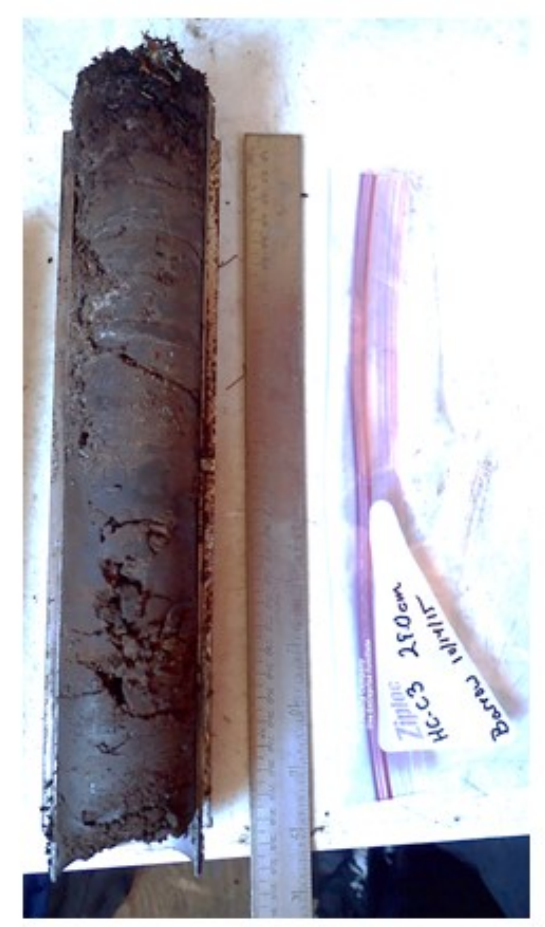

HCP-Center (3)

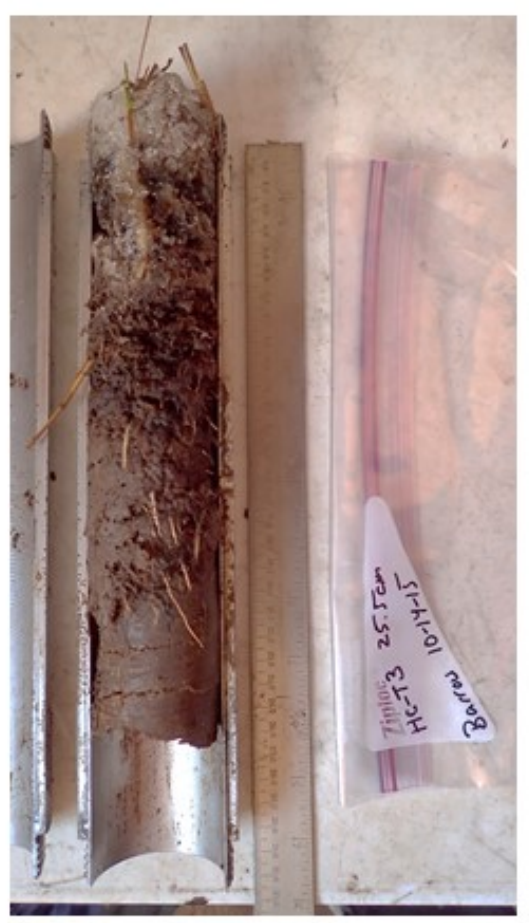

HCP-Trough (3) 

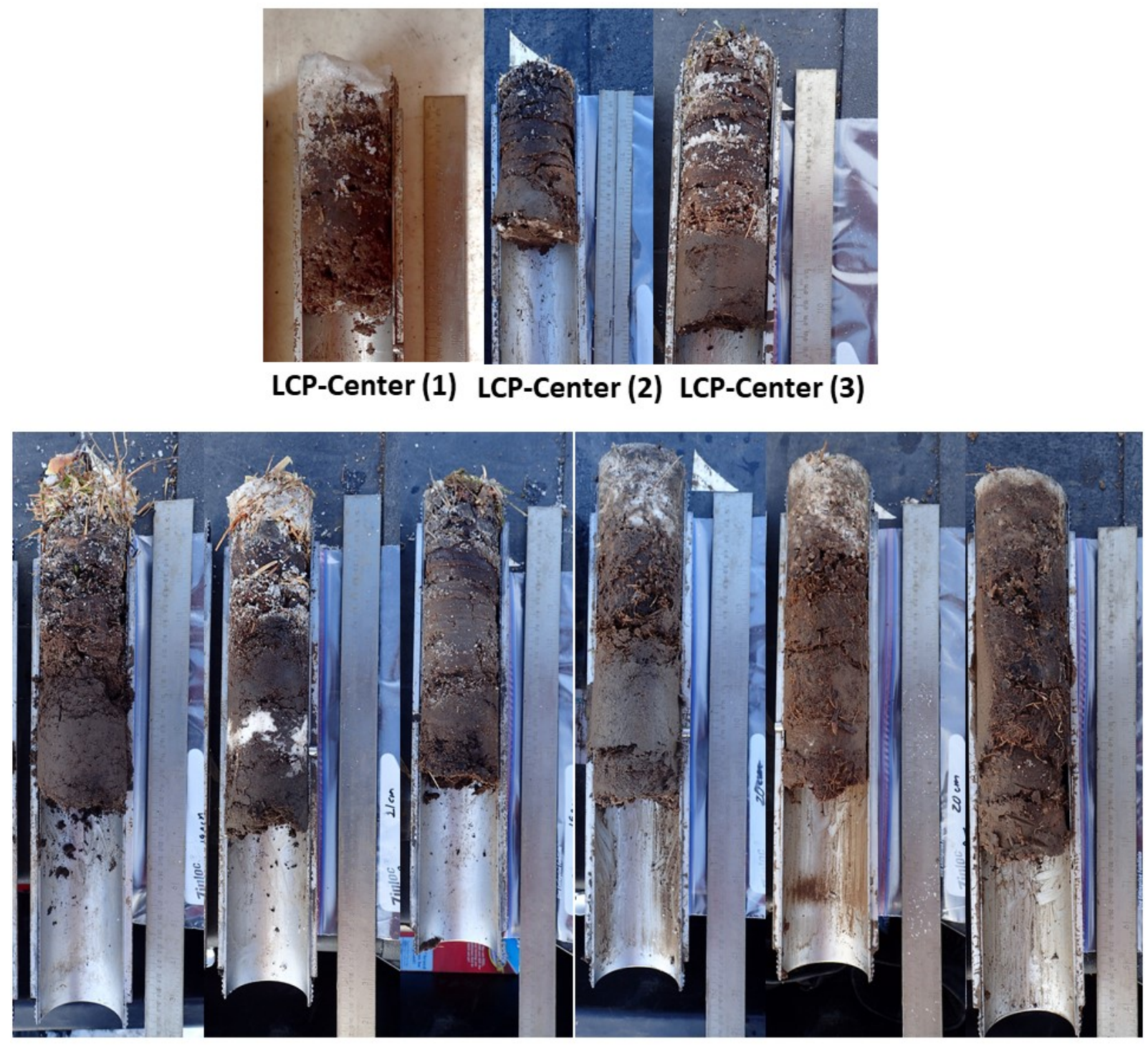

LCP-Ridge (1) LCP-Ridge (2) LCP-Ridge (3) LCP-Trough (1) LCP-Trough (2) LCP-Trough (3)

Figure 5: 15 soil cores were collected by S. Wullschleger on October 15, 2015 at Barrow Environmental Observatory. Replicate cores $(n=3)$ were obtained from each location (LCPCenter, LCP-Ridge, LCP Trough, HCP-Center, and HCP-Trough). Boundary between mineral and organic horizon was identified, excluding low-centered polygon center (LCP-Center) in which organic horizon was solely identified. Organic horizons were identified by the presence of organic roots and less dense material. The shift into mineral horizon (where applicable) was identified by color change and more dense material. 


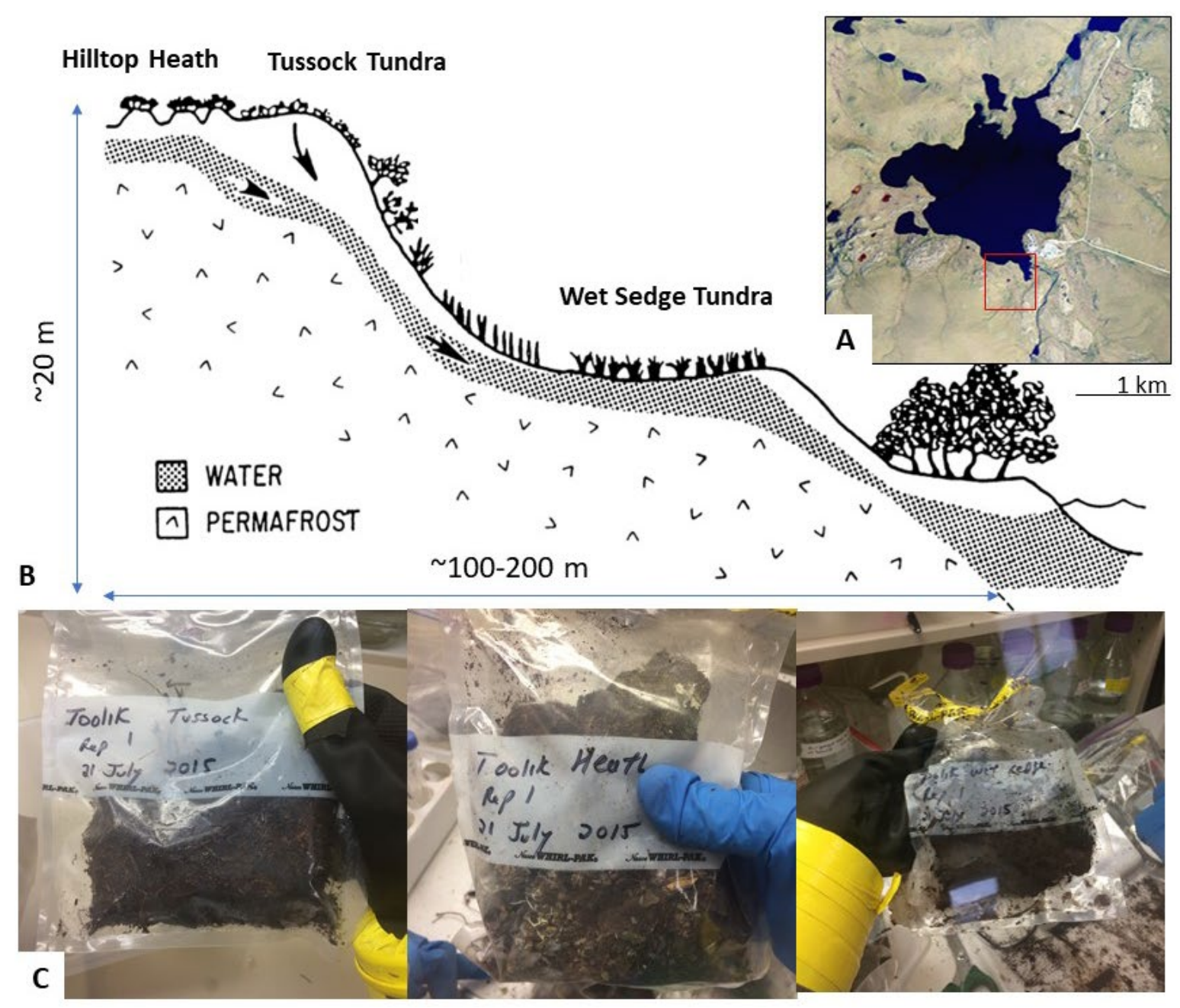

Figure 6: Nine surface samples were collected from Toolik Field Station (TFS). A) Toolik Field Station is a part of the Long-Term Ecological Research (LTER) network, located around Toolik Lake on the Alaskan North Slope at the foothills of the Brooks Range, AK (photo:

Toolik.Alaska.edu). B) Hilltop heath and tussock tundra sample locations represent a general upgradient topographic position compared to the saturated downgradient wet sedge tundra. Note, permafrost is not characterized to fully thaw in the hilltop heath and tussock tundra sampling points (photo: modified from Giblin et al. 1991). C) Three replicates were collected from each sample location. Samples were processed in an anaerobic glove box. 


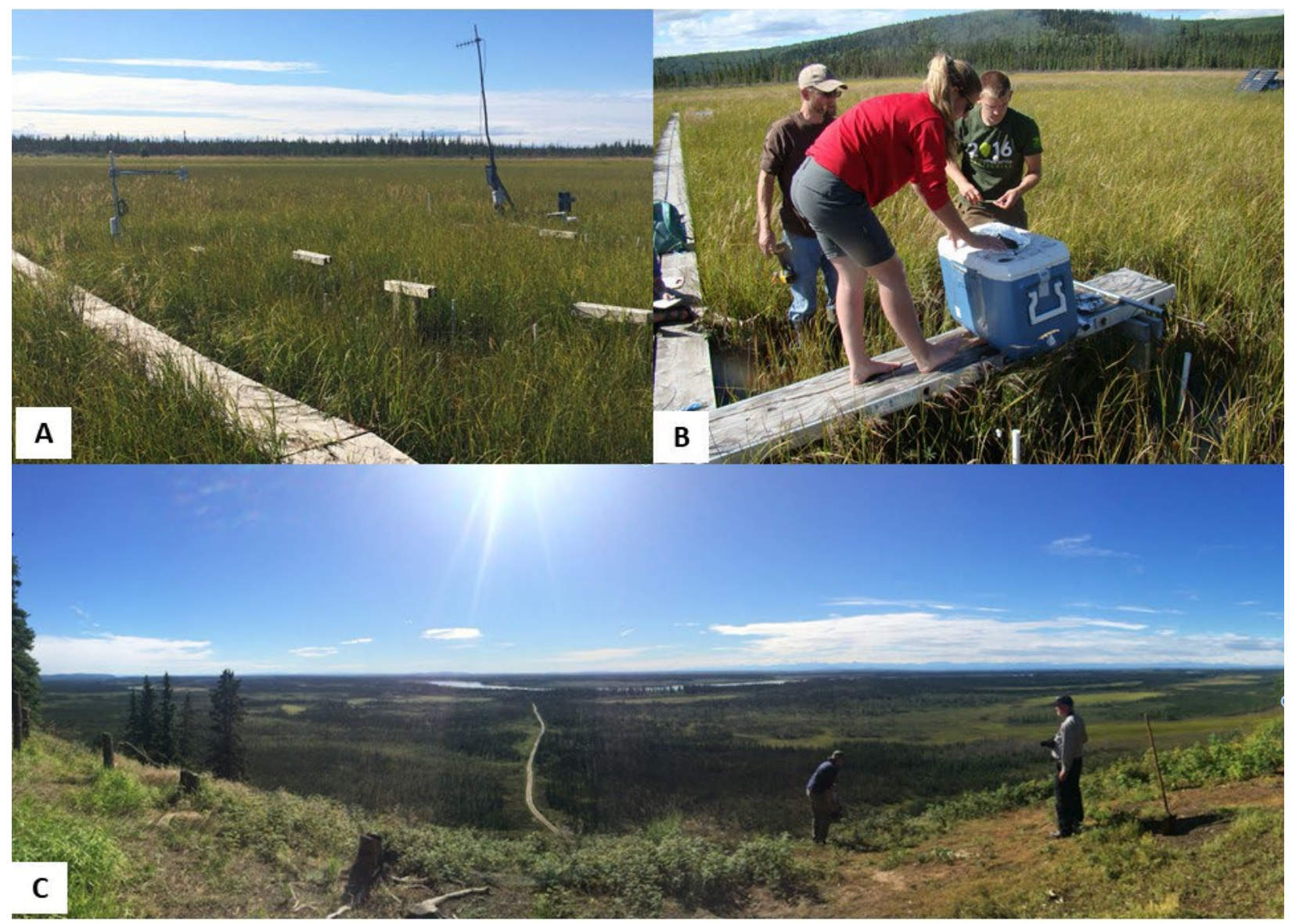

Figure 7: These photos were taken by our field crew during the July 2016 sampling event. A total of nine soil cores and 21 water samples from various depths were collected for analyses. A) The APEX site is a moderate-rich fen located within the Tanana River floodplain. B) Three replicate soil cores were collected from each treatment 20x20 m plot (raised, lowered, and control water treatment). Soil cores were extracted using a 1" diameter drill-powered auger and collected from the base of the living vegetation down to the point of refusal, measured, and processed for shipment back to Kent State University. C) The experimental plots are located in a relatively low- lying topographic position. This photo is showing our field crew on a near-by hilltop, over looking the area where the APEX site lays. 


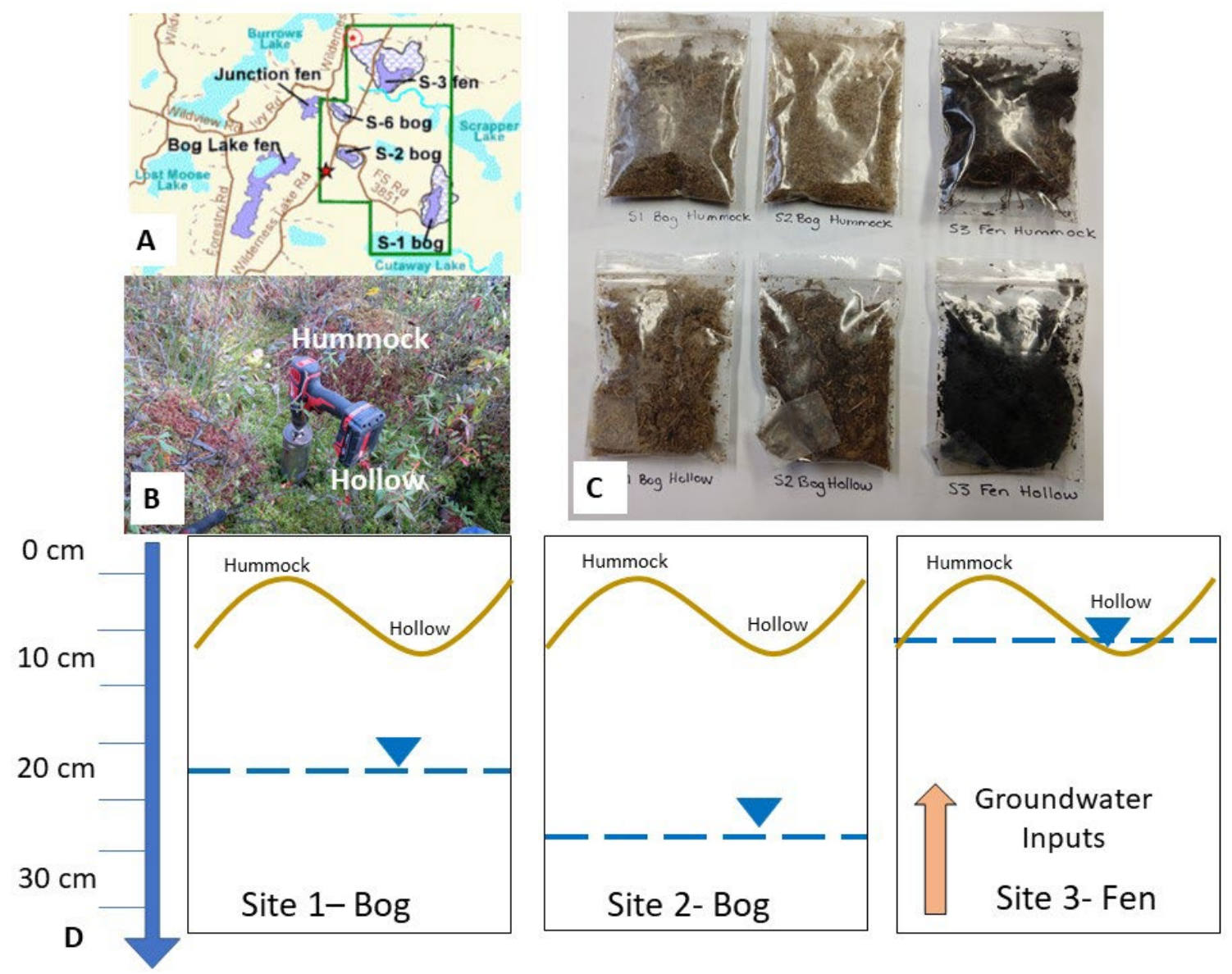

Figure 8: The Marcell Experimental Forest (MEF) is an 890 ha research area that sits at the southern margin of a boreal peatland forest biome in Northern Minnesota. A) MEF contains six experimental watersheds (5 bogs, 1 fen) (photo: nrs.fs.fed.us) B) Hummocks are typically elevated and dry relative to depressed and saturated hollows. C) 18 surface soil samples were collected within about a 1x1 m area from the base of living Sphagnum moss to $20 \mathrm{~cm}$ depth with a 3" stainless steel drill corer with a serrated bottom edge. This figure shows representative dried soils collected from each site. D) Six samples from each site (Site 1-bog, Site 2-bog, and Site 3-bog) were collected; three from hummock microtopographic position and three from hollow microtopographic position. Relative water table position varied between the three sites. 


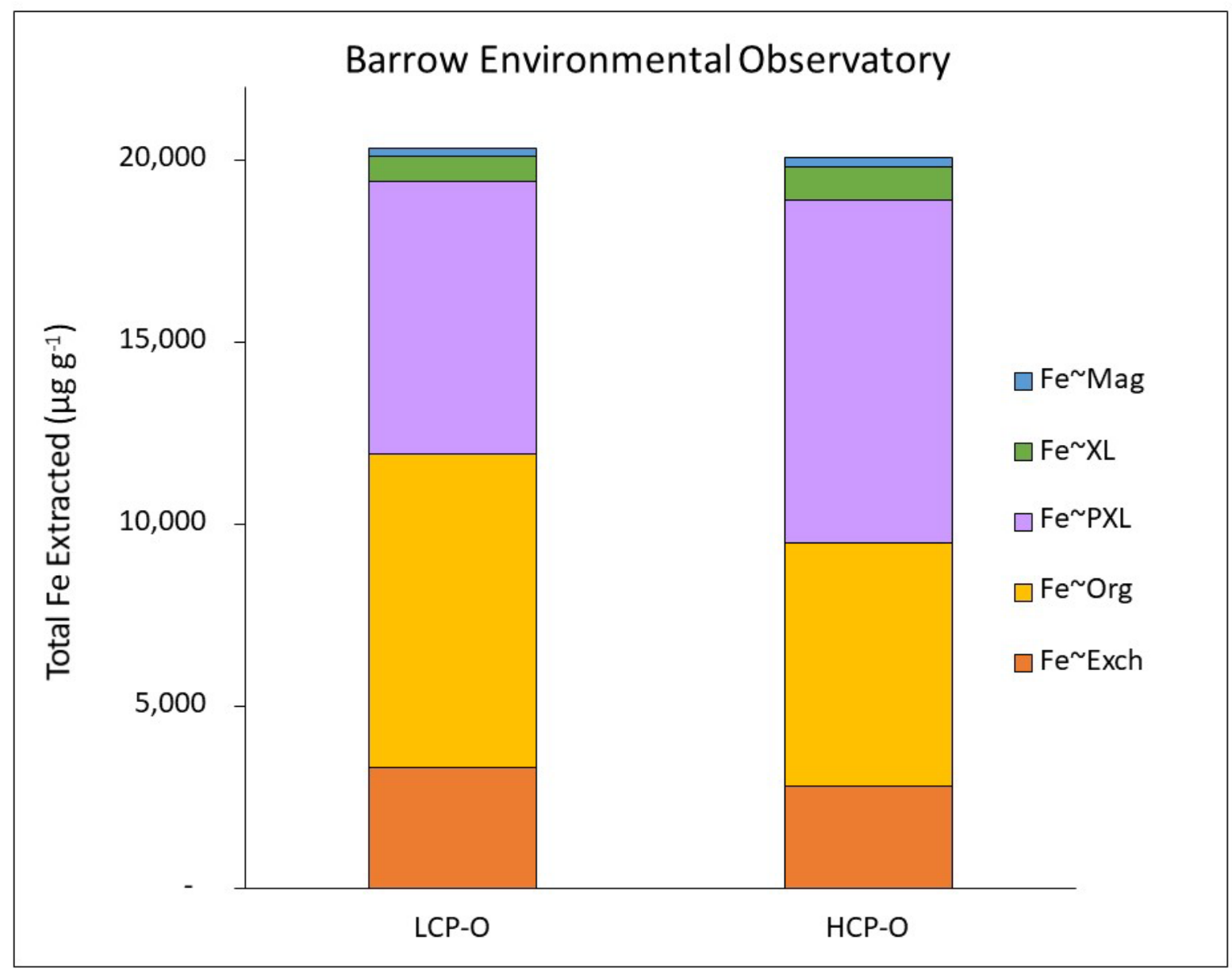

Figure 9: This graph represents the average of ridge, center, and trough organic horizon cores from low-centered and high-centered polygons. Total concentrations of extracted Fe were comparable between low-centered organic (LCP-O; 20,339 $\pm 3,434 \mu \mathrm{g}$ g-soil ${ }^{-1}$ ) and highcentered organic (HCP-O; 20,086 $\pm 5,076 \mu \mathrm{g}$ g-soil ${ }^{-1}$ ) horizons. Exchangeable iron (Fe $\sim$ Exch), organic-bound iron (Fe Org), and poorly crystalline iron oxyhydroxide (Fe PXL) fractions comprised the majority of extracted iron in all features, while lesser concentrations of Fe were present in crystalline $(\mathrm{Fe} \sim \mathrm{XL})$ and magnetite $(\mathrm{Fe} \sim \mathrm{Mag})$ fractions. 
Organic Horizon: Exchangeable Fe

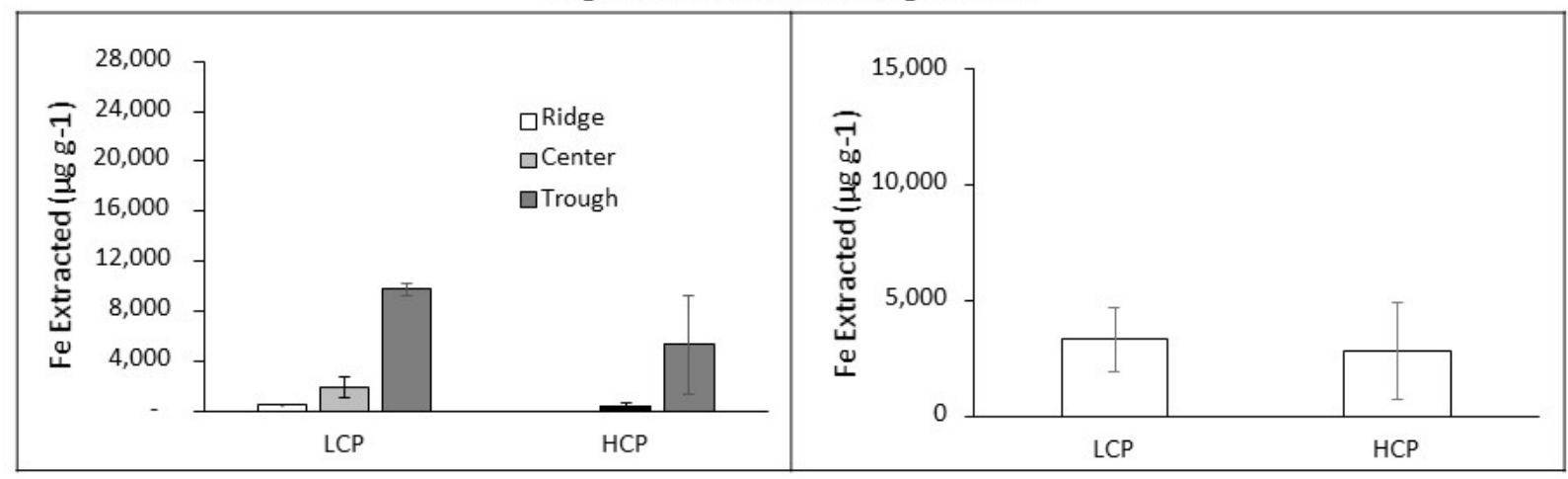

Organic Horizon: Organic-bound Fe

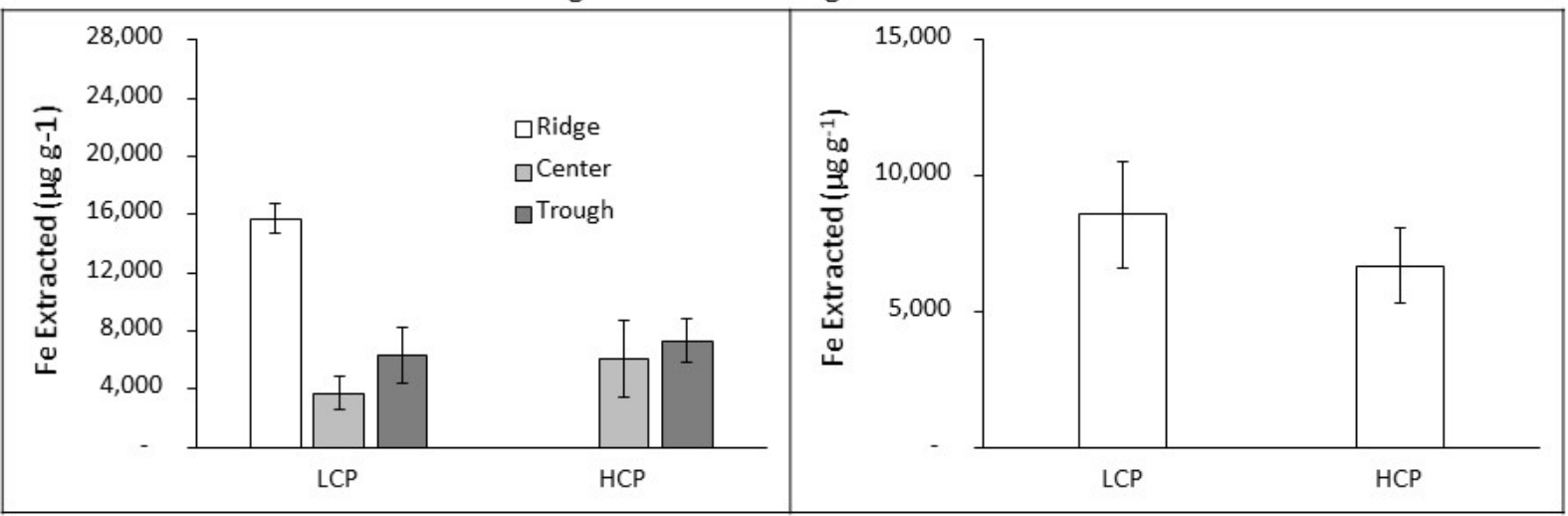

Organic Horizon: Poorly Crystalline Fe

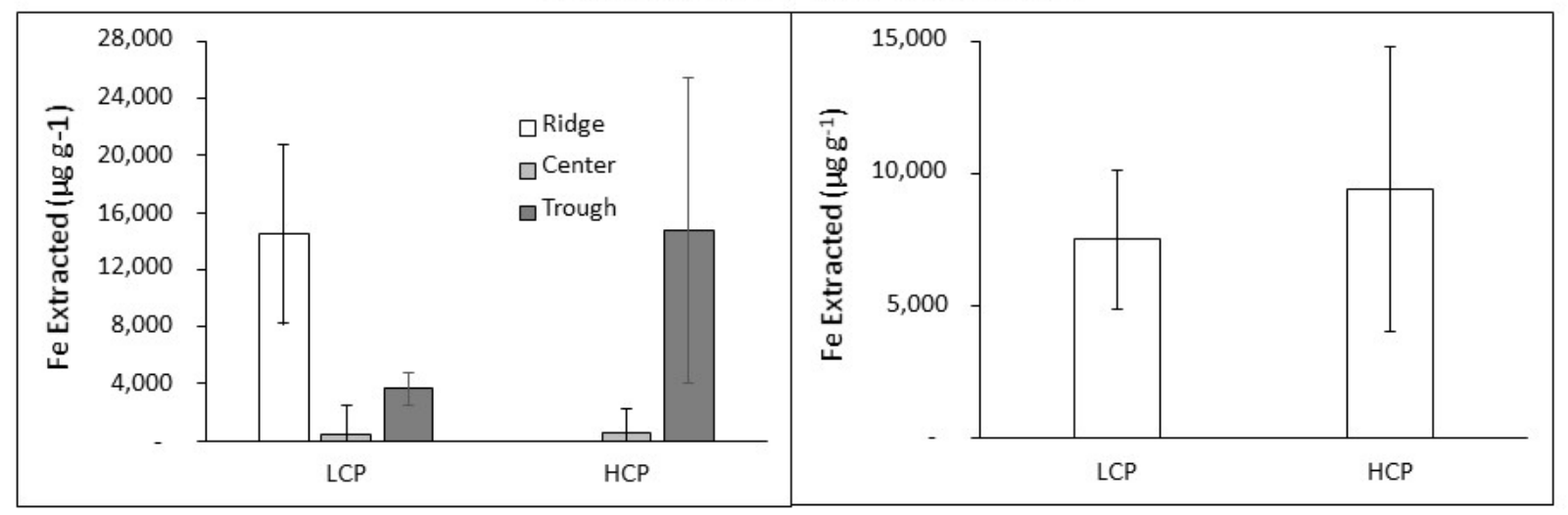


Organic Horizon: Crystalline Fe

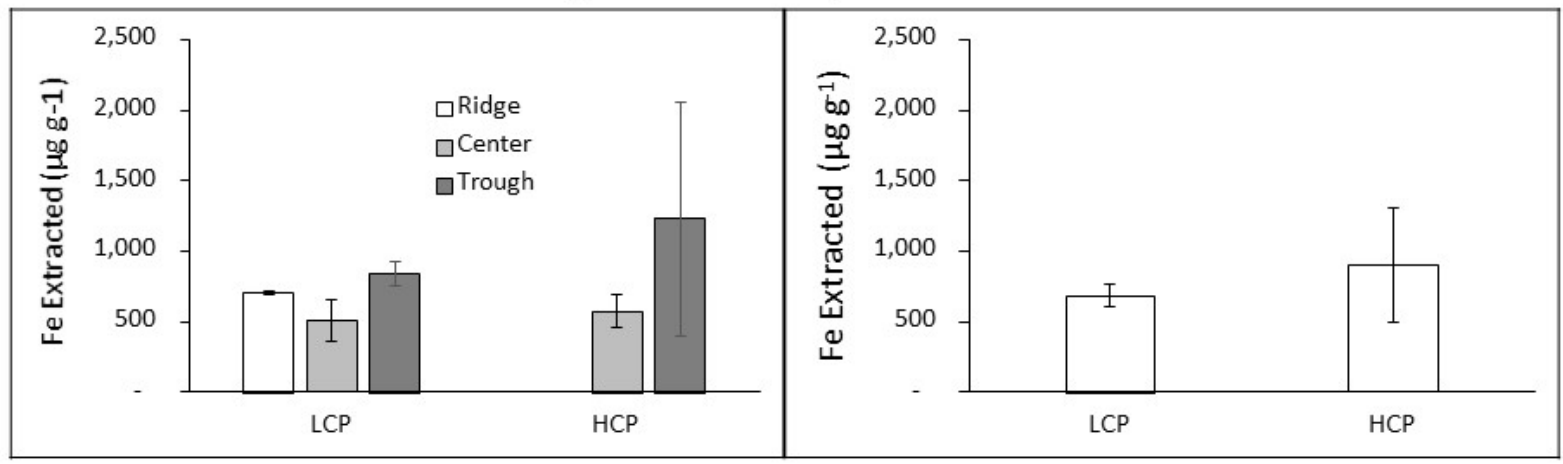

Organic Horizon: Magnetite Fe

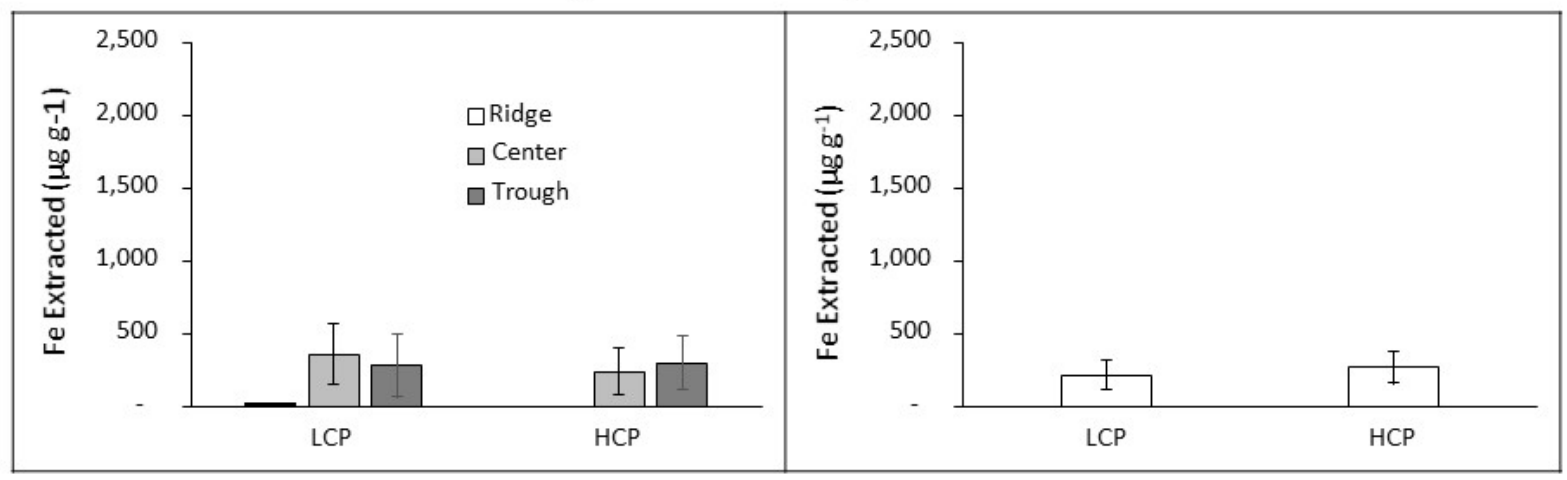

Figure 10: Fe concentrations ( $\mu \mathrm{g}$ g-soil $\left.{ }^{-1}\right)$ in extractable soil fractions defined as exchangeable, organic-bound, poorly crystalline, crystalline, and magnetite. The panels on the left show average Fe concentration in organic soil for each topographic feature within each polygon. The panels on the right show the averaged concentration of iron extraction pool of the organic horizon across all topographic features. Note that the y-axis range is the same for exchangeable, organic-bound, and poorly crystalline Fe but different for crystalline and magnetite Fe due to the lower yield. 

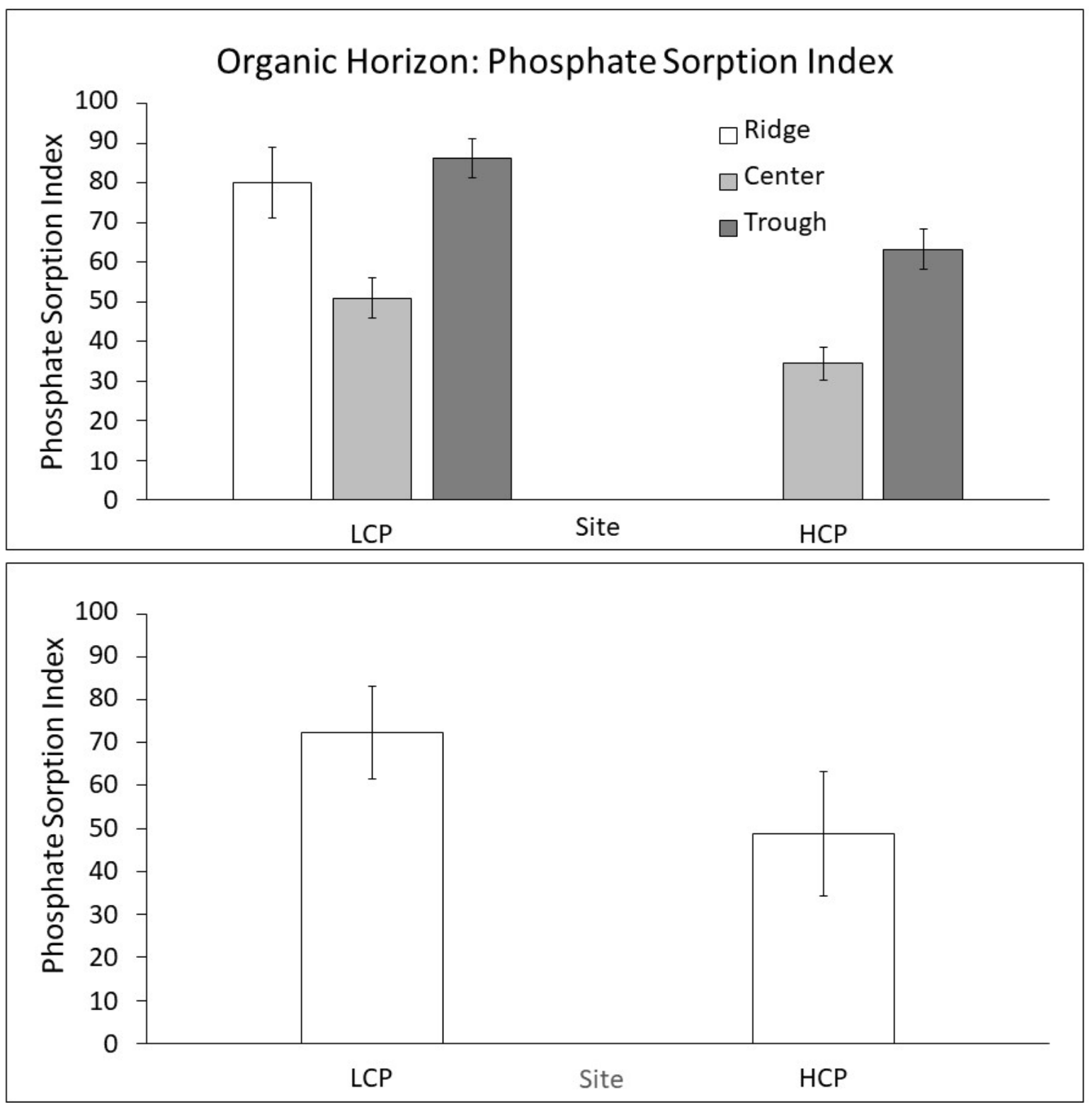

Figure 11: (Top) Low-centered polygons possess a greater ability to sorb phosphate independent of the microtopographic feature (i.e. ridge, center, trough). (Below) Organic horizons in the lowcentered polygon exhibited a higher capacity to sorb phosphate (Phosphate Sorption Index $=72.4$ $\pm 10.9)$ than in the high-centered polygons (PSI $=48.9 \pm 14.4)$. 


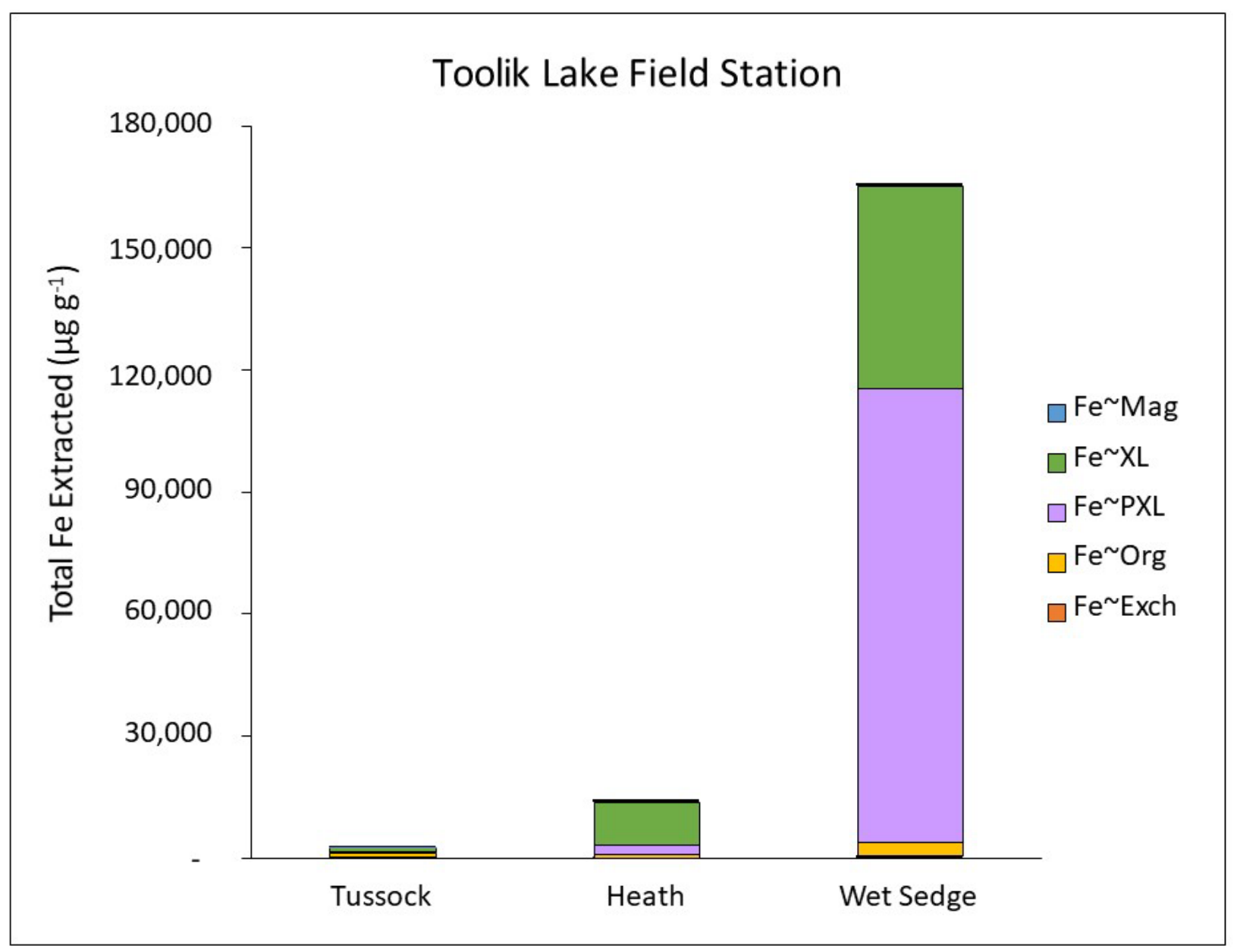

Figure 12: Dominant fractions of extracted iron at the Toolik Lake Field Station were represented by crystalline and poorly crystalline iron oxides. Organic-bound iron was also a larger contributor to overall iron sequestering compared to exchangeable and/or magnetite iron. Importantly, the total extracted Fe was over 20 times higher in the wet sedge soils $(165,626 \pm$ $21,747 \mu \mathrm{g}$ g-soil $\left.^{-1}\right)$ than the heath $\left(7,932 \pm 1,970 \mu \mathrm{g}\right.$ g-soil $\left.{ }^{-1}\right)$ and tussock tundra sites $(2,562 \pm$ $232 \mu \mathrm{g}$ g-soil $\left.{ }^{-1}\right)$. 

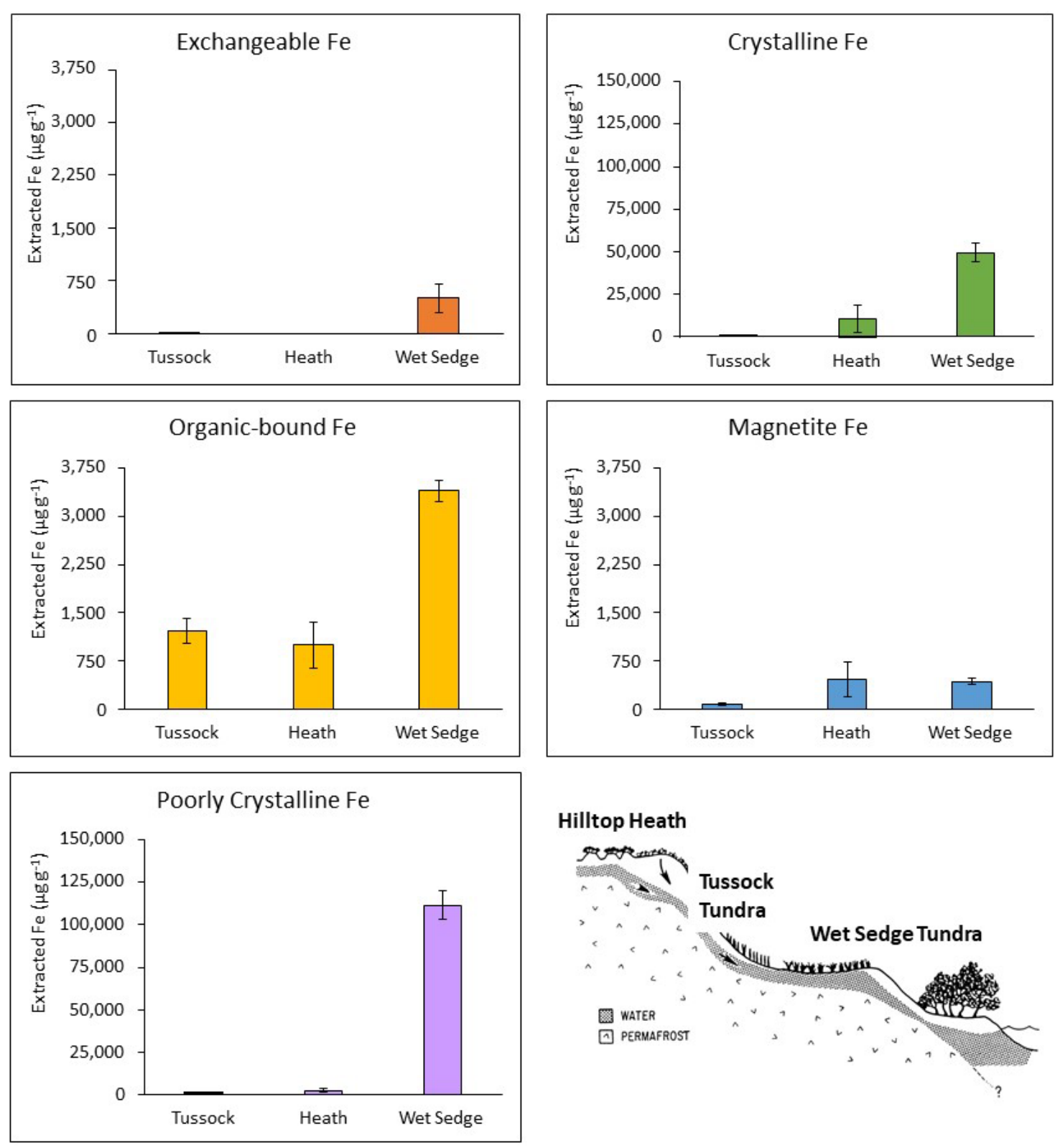

Figure 13: The vertical scale of Fe has been set equal for manageable visual discrepancy with the following exception; Crystalline Fe and Poorly crystalline Fe graphs have been scaled up 40 times due to their comparatively large yield. Note this extreme difference in scale, reiterating the strong presence of both forms of iron oxides. The largest percentage and concentration of Fe extracted at the wet wedge site was represented by the poorly crystalline Fe (hydr)oxides (67\%; $111,671 \pm 30 \mu \mathrm{g}$ g-soil $\left.{ }^{-1}\right)$ while crystalline oxides comprised the largest concentration and percentage in heath soils $\left(75 \% ; 10,588 \pm 7,741 \mu \mathrm{g} \mathrm{g}^{-1}\right)$. The tussock tundra's largest pool of extracted iron was organic-bound Fe $\left(47 \% ; 1,211 \pm 199 \mu \mathrm{g} \mathrm{g}^{-1}\right)$. 


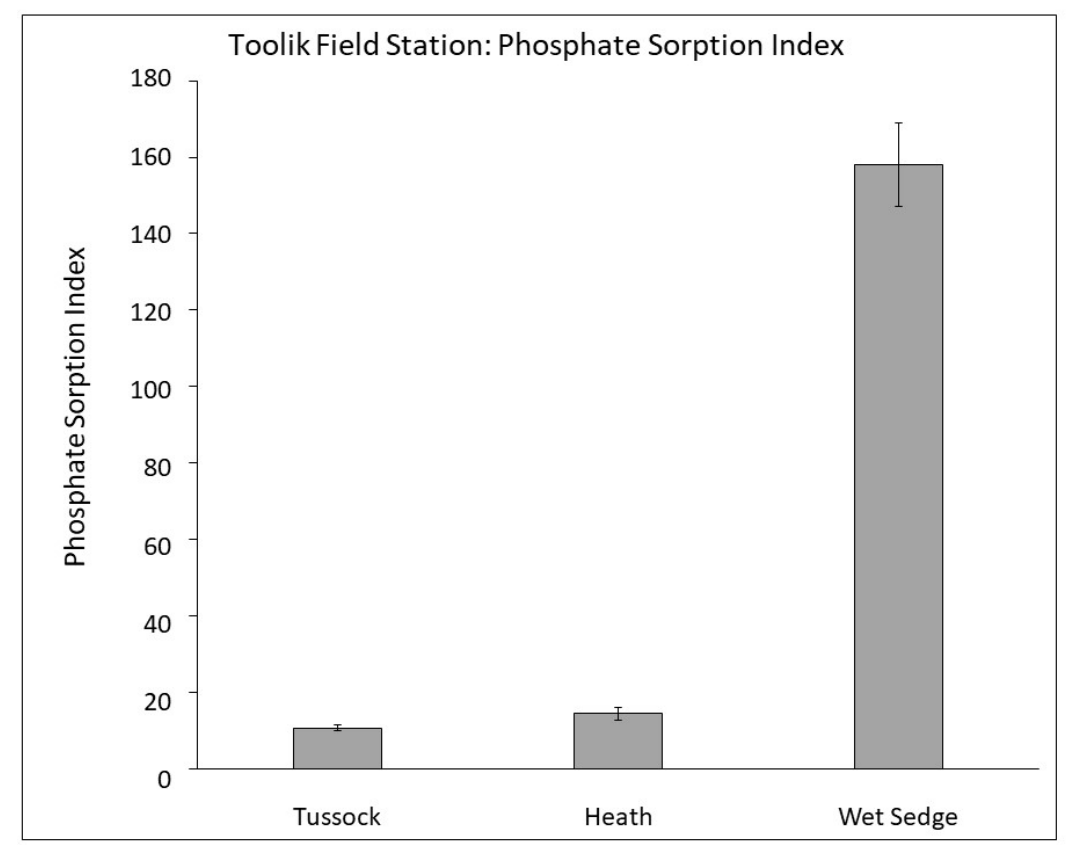

Figure 14: Wet sedge soils had substantially higher PSI $(158 \pm 11)$ than soil from the tussock tundra $(11 \pm 0.84)$ and heath $(14 \pm 1.63)$ soils.

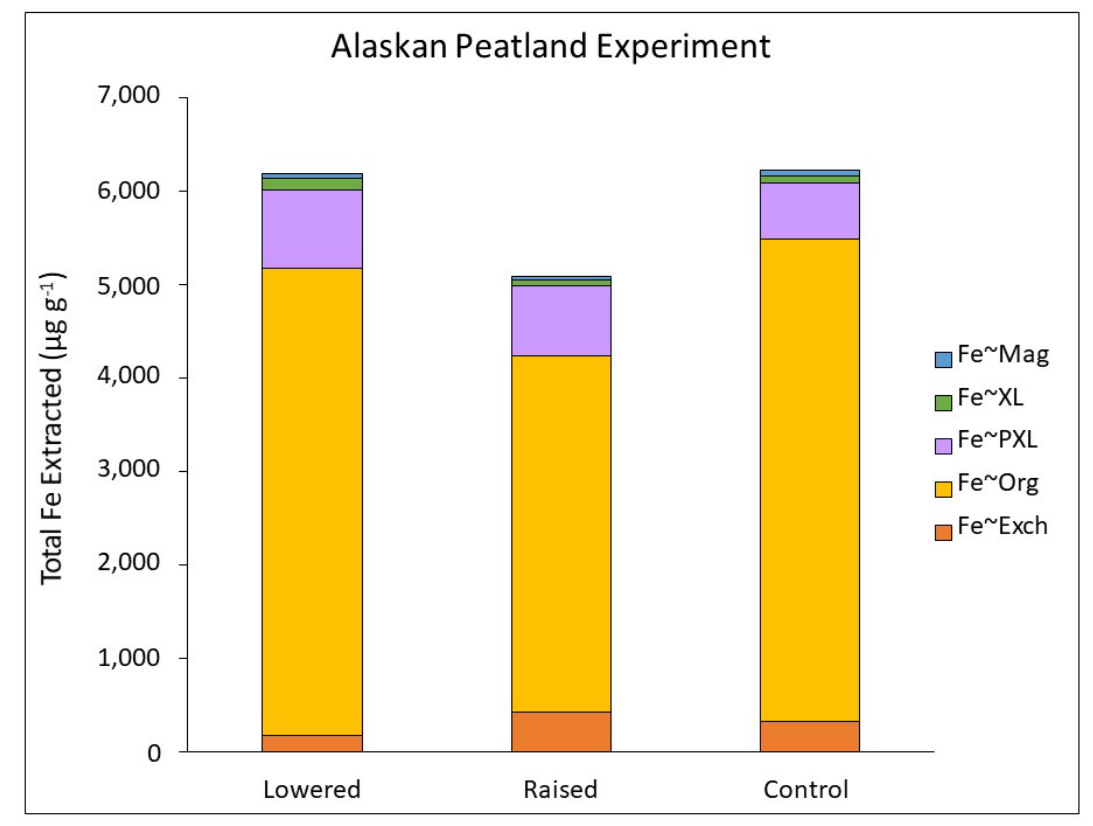

Figure 15: Visible in the graph above, organic-bound iron dominates iron speciation at the Alaskan Peatland Experiment. Following in less dominant pools are poorly crystalline iron and exchangeable iron. Furthermore, between the three manipulated water table plots (lowered, raised, and plot with no manipulation), there is low variance. 

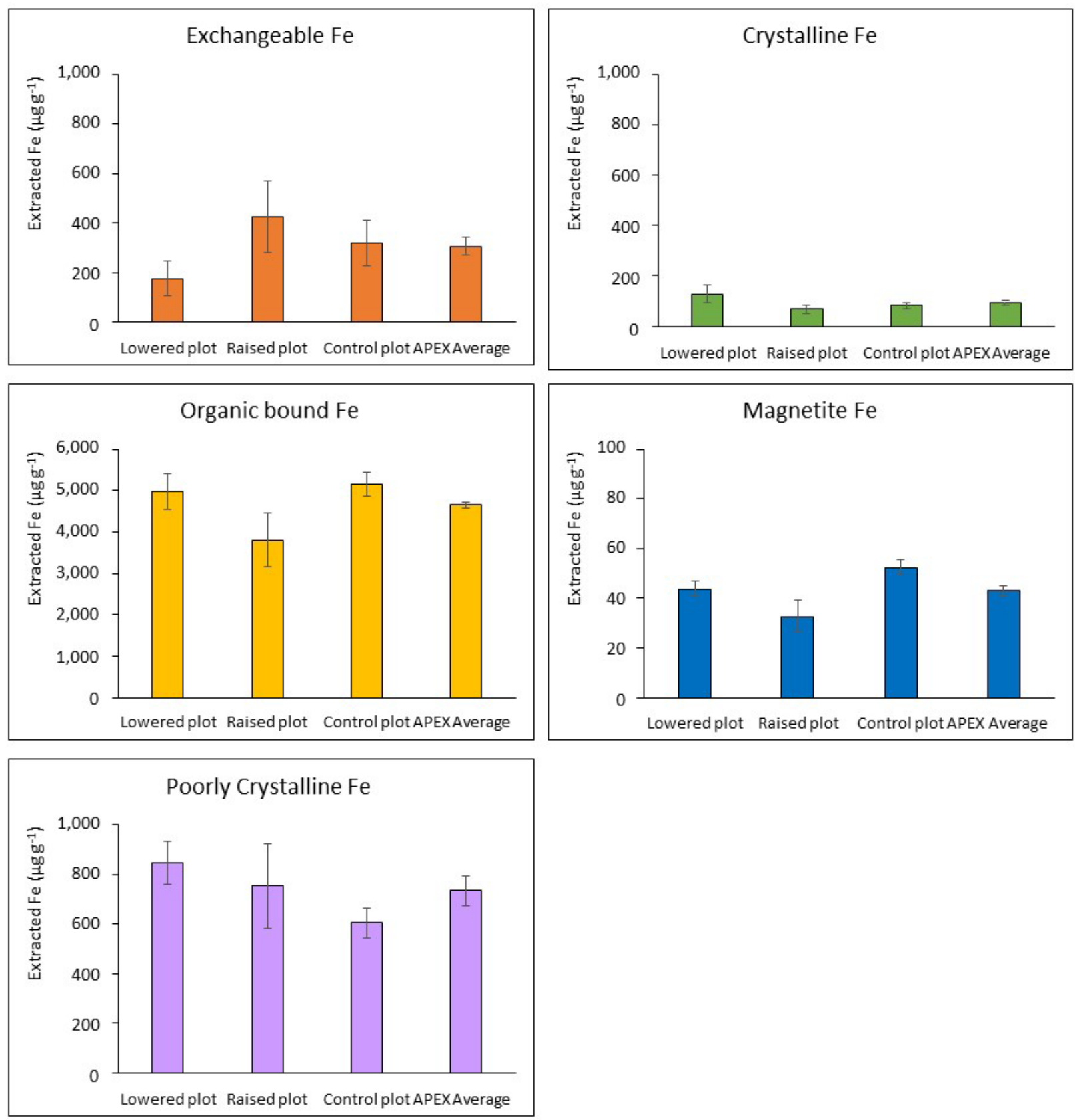

Figure 16: The vertical scale of Fe has been set as divisible quantities by a factor of 100 for manageable visual discrepancies. Organic bound iron scale is 60 times greater than the magnetite scale and 6 times greater than exchangeable Fe, poorly crystalline, and crystalline iron scales. Note this extreme difference in scale, reiterating the strong presence of organic bound $\mathrm{Fe}$. The average of each fraction is represented by the far right bar of each graph. 


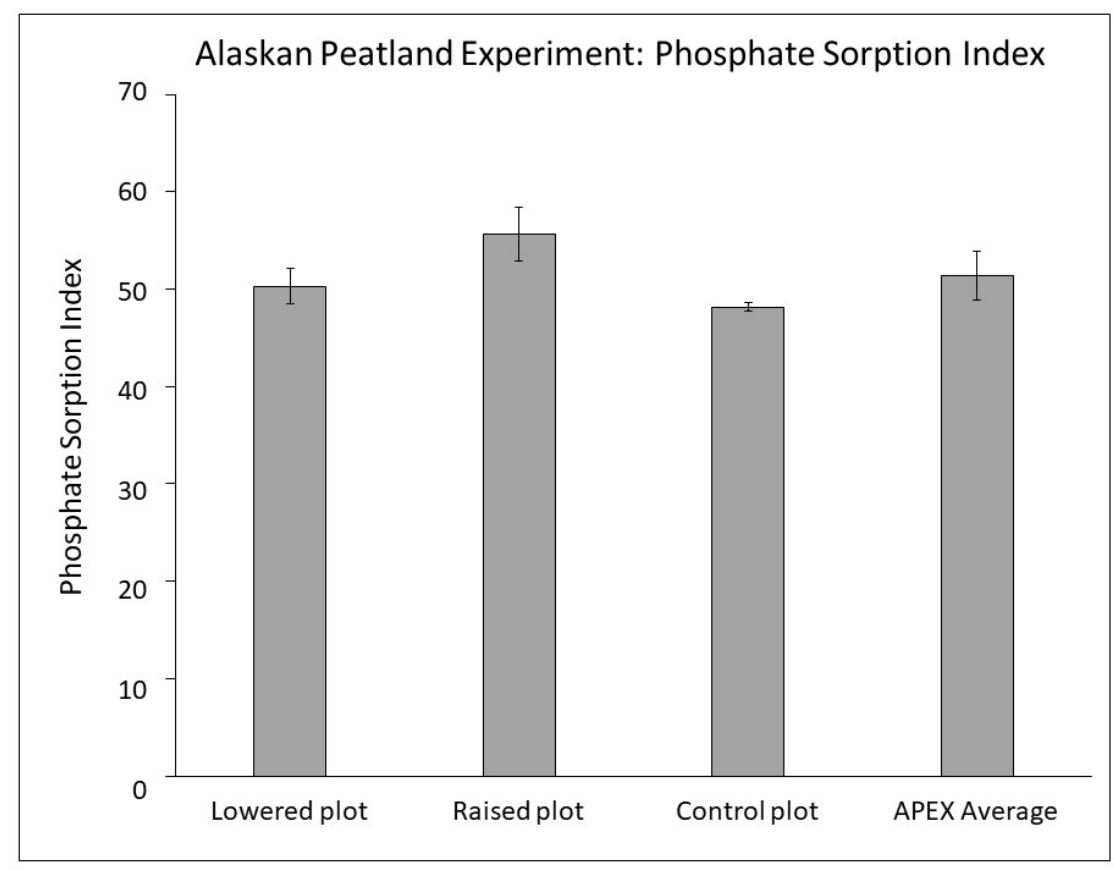

Figure 17: Consistent with the iron extraction results, the phosphate sorption index results show little variance. The average PSI (far right) was $51.4 \pm 2.5$, indicating a moderate ability for the organic soils at APEX to sequester phosphate relative to the other sites.

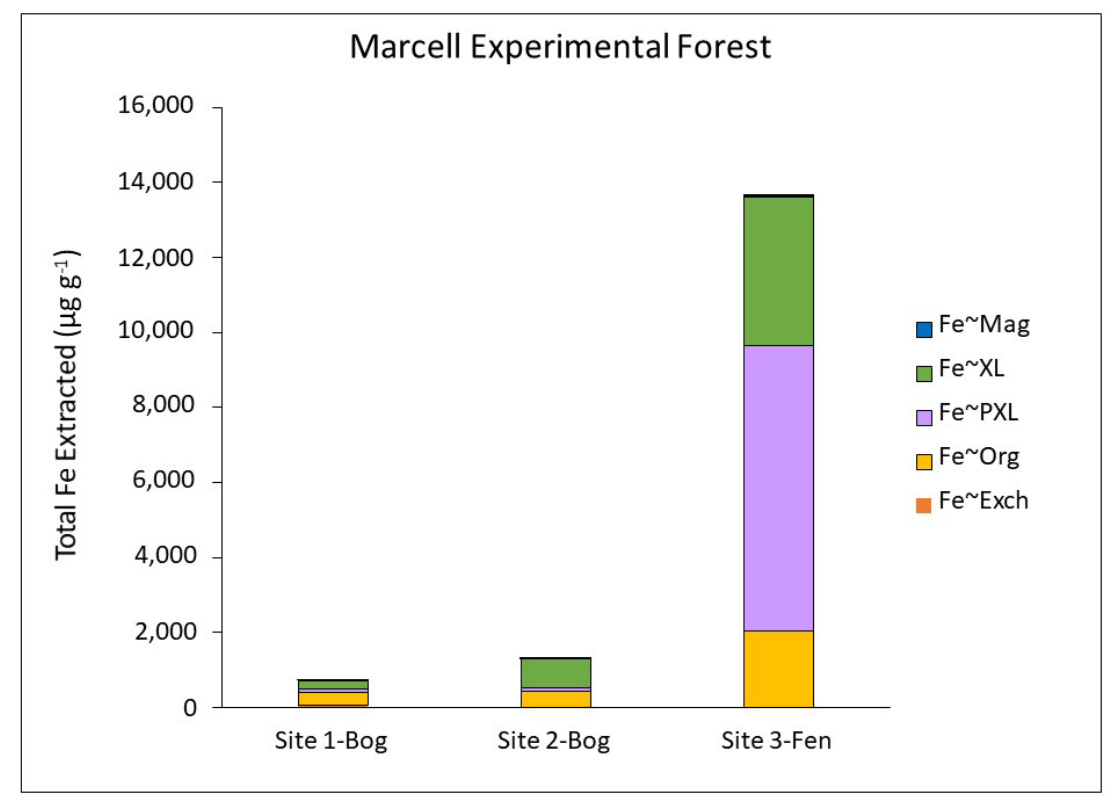

Figure 18: Soils from the Site 3 fen had the overall average highest concentration of total extracted iron $\left(3,412 \pm 1,318 \mu \mathrm{g} \mathrm{g}_{\text {-soil }}{ }^{-1}\right)$ compared to the S1-bog $\left(147 \pm 62 \mu \mathrm{g}\right.$ g-soil $\left.{ }^{-1}\right)$ and S2bog $\left(262 \pm 130 \mu \mathrm{g}\right.$ g-soil $\left.{ }^{-1}\right)$. Dominating fractions include poorly crystalline and crystalline oxides. 

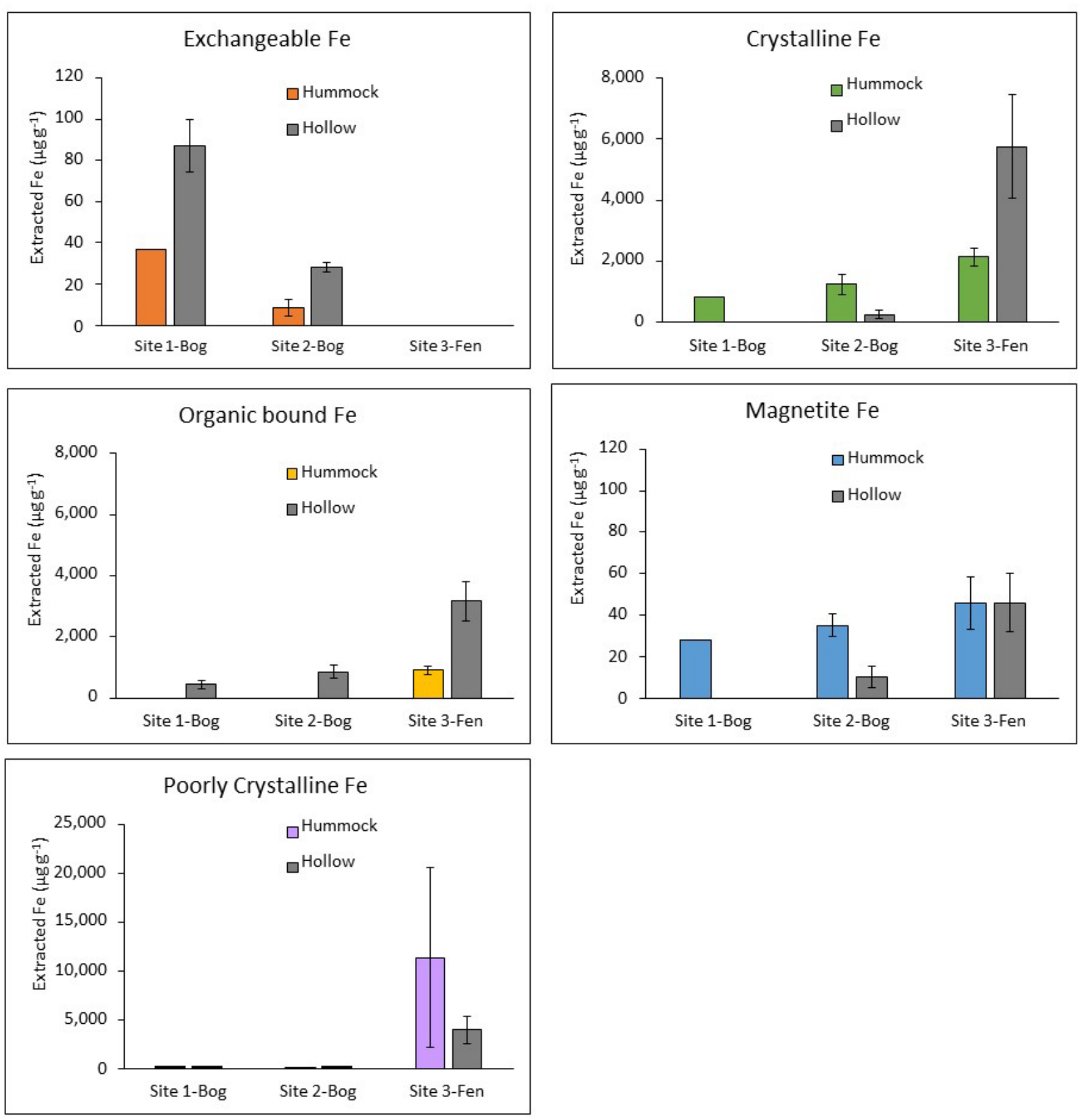

Figure 19: Hummock microtopographic features exhibit an overall larger concentration of extracted iron (1378 $\pm 779 \mu \mathrm{g}$ g-soil-1) compared to the hollow features $(988 \pm 302 \mu \mathrm{g}$ g- soil-1). The largest pool of extracted iron within the bogs was crystalline iron oxides (47\%), followed closely by organic-bound iron (37\%). S3-fen contained higher concentrations of poorly crystalline $\mathrm{Fe}\left(7,623 \pm 4,467 \mu \mathrm{g}\right.$ g-soil $\left.{ }^{-1}\right)$, crystalline $\mathrm{Fe}\left(3,946 \pm 1,115 \mu \mathrm{g} \mathrm{g}\right.$-soil $\left.{ }^{-1}\right)$, and organic bound $\mathrm{Fe}\left(2,033 \pm 581 \mu \mathrm{g} \mathrm{g}\right.$-soil $\left.{ }^{-1}\right)$ than the bogs, with poorly crystalline Fe constituting the greatest proportion of extracted $\mathrm{Fe}(56 \%)$. 


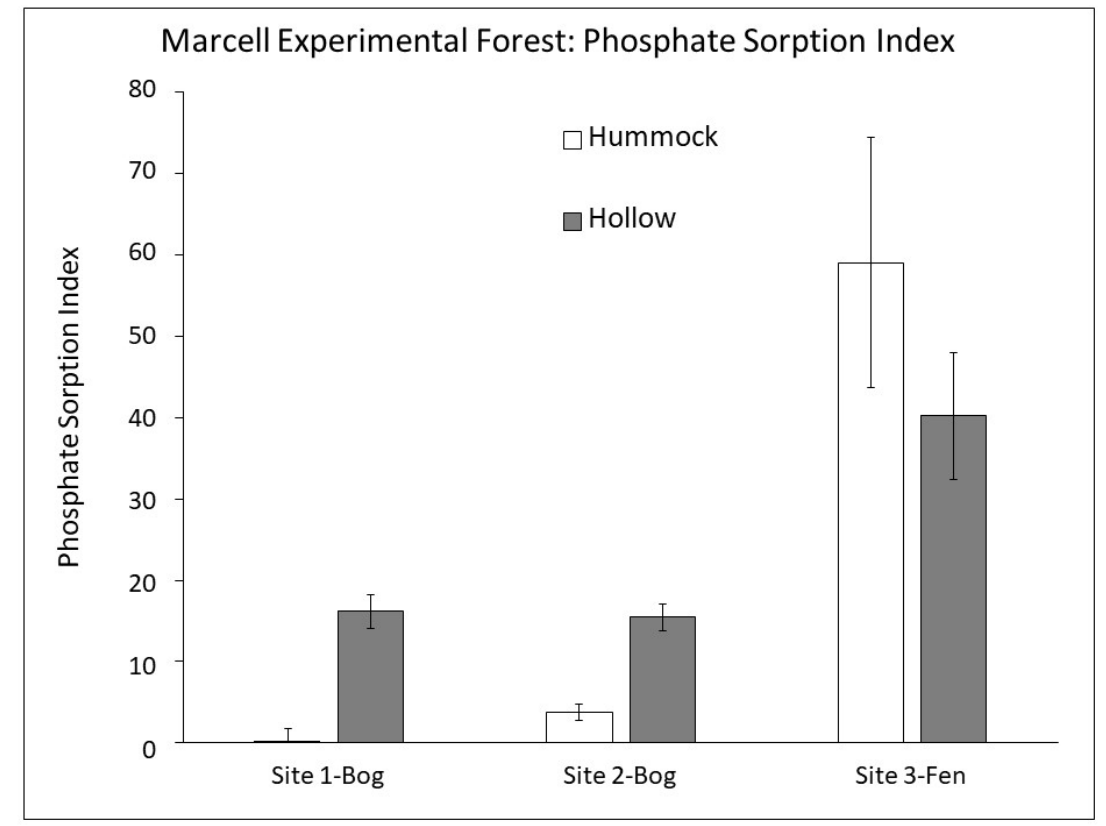

Figure 20: Average PSI in the S3 fen soils $(50 \pm 9.4)$ was higher than in S1 and S2 bog soils (avg $8.9 \pm 4.1)$. Within S1 and S2-bogs, the hollow features exhibited a greater PSI (16 \pm 0.36$)$ than the hummocks $(1.98 \pm 1.8)$. The PSI has an opposite trend at S3 where the hummocks $(59 \pm 15)$ had a greater PSI than the hollows $(40 \pm 7.8)$.

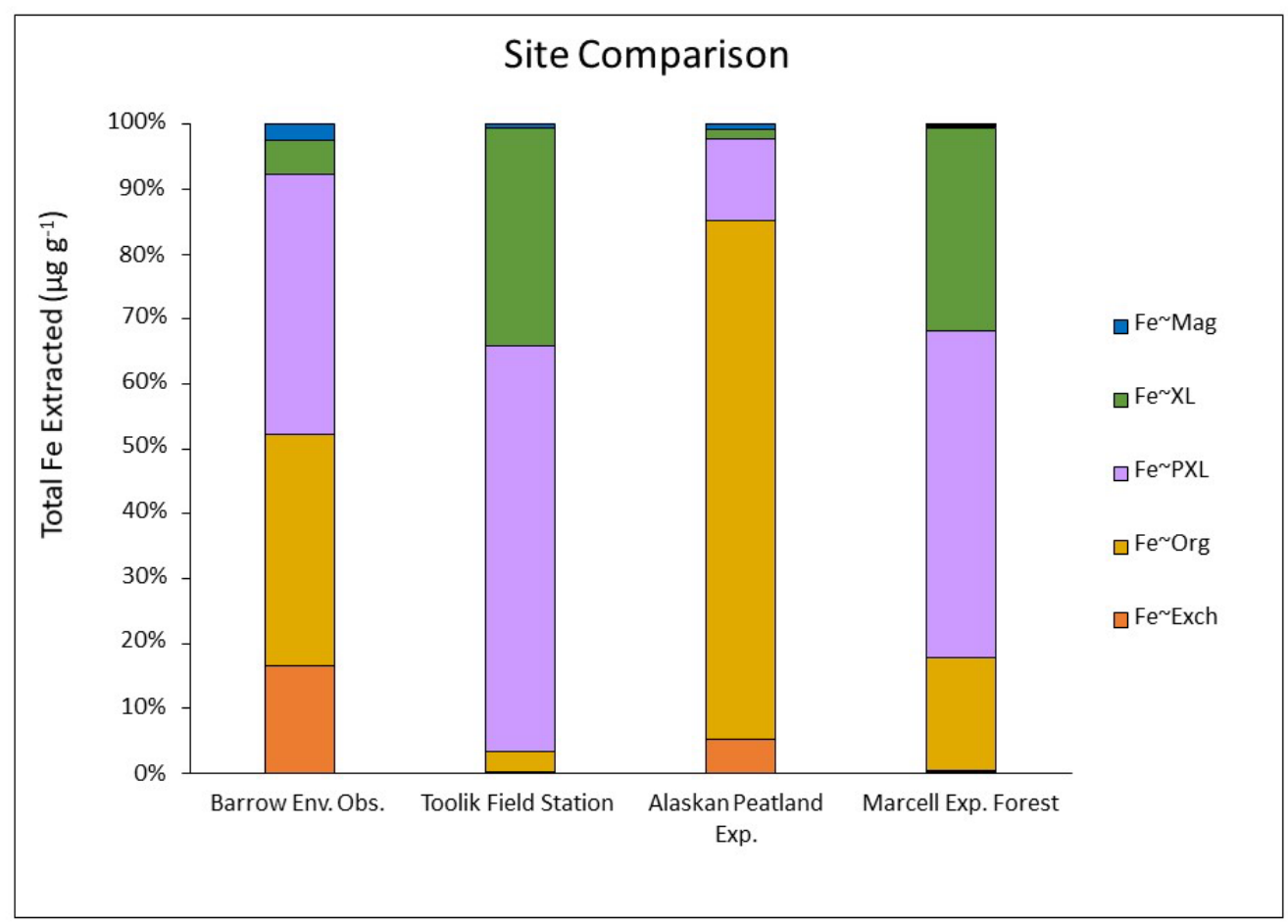

Figure 21: Site comparison of extracted iron fractions. Fractions from each site were averaged and represented as percentage out of $100 \%$. 


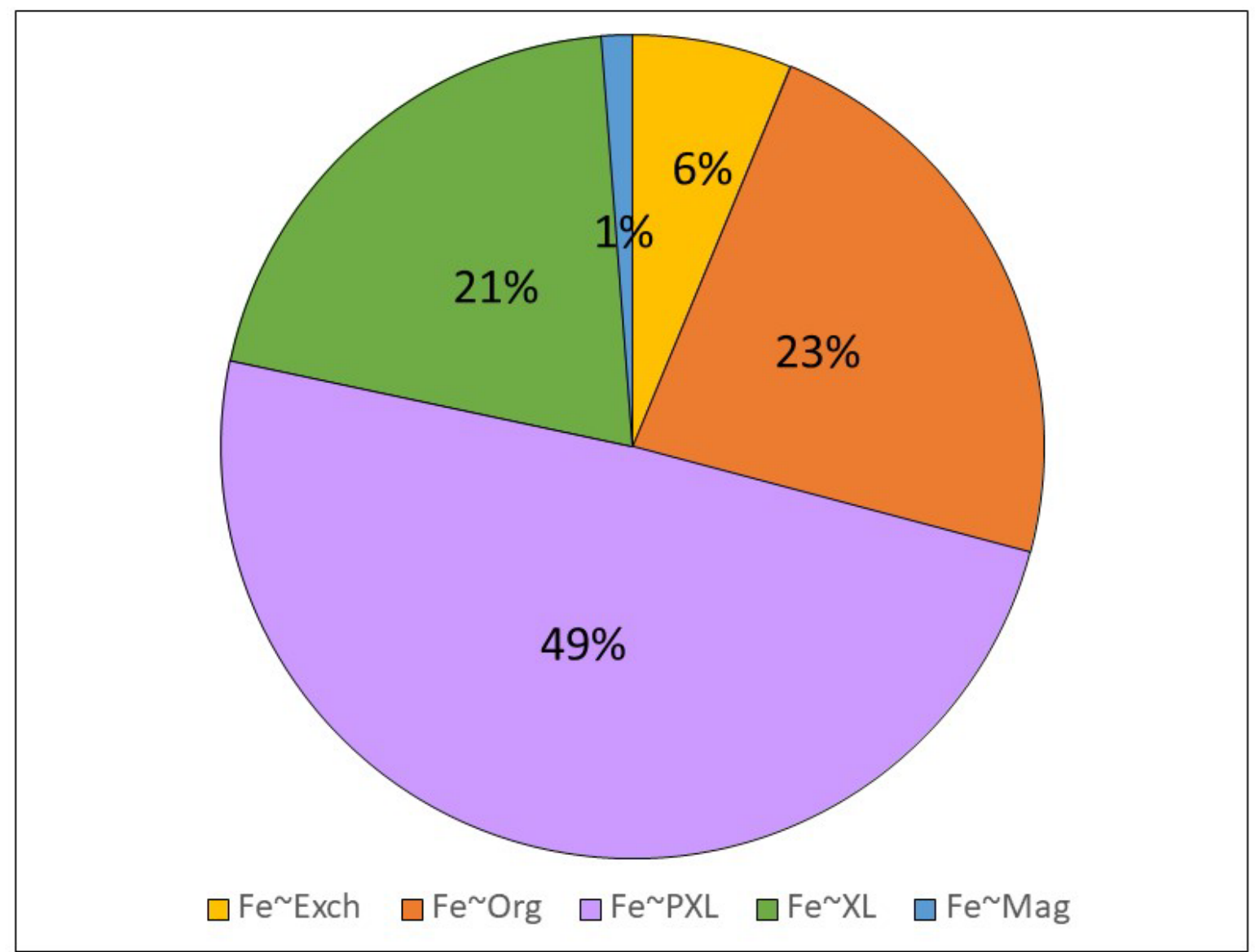

Figure 22: Pie graph shows total averaged iron for each fraction amongst all four study sites. Poorly-crystalline iron oxides made up the largest extracted pool of iron at $49 \%$ of total extracted iron. 

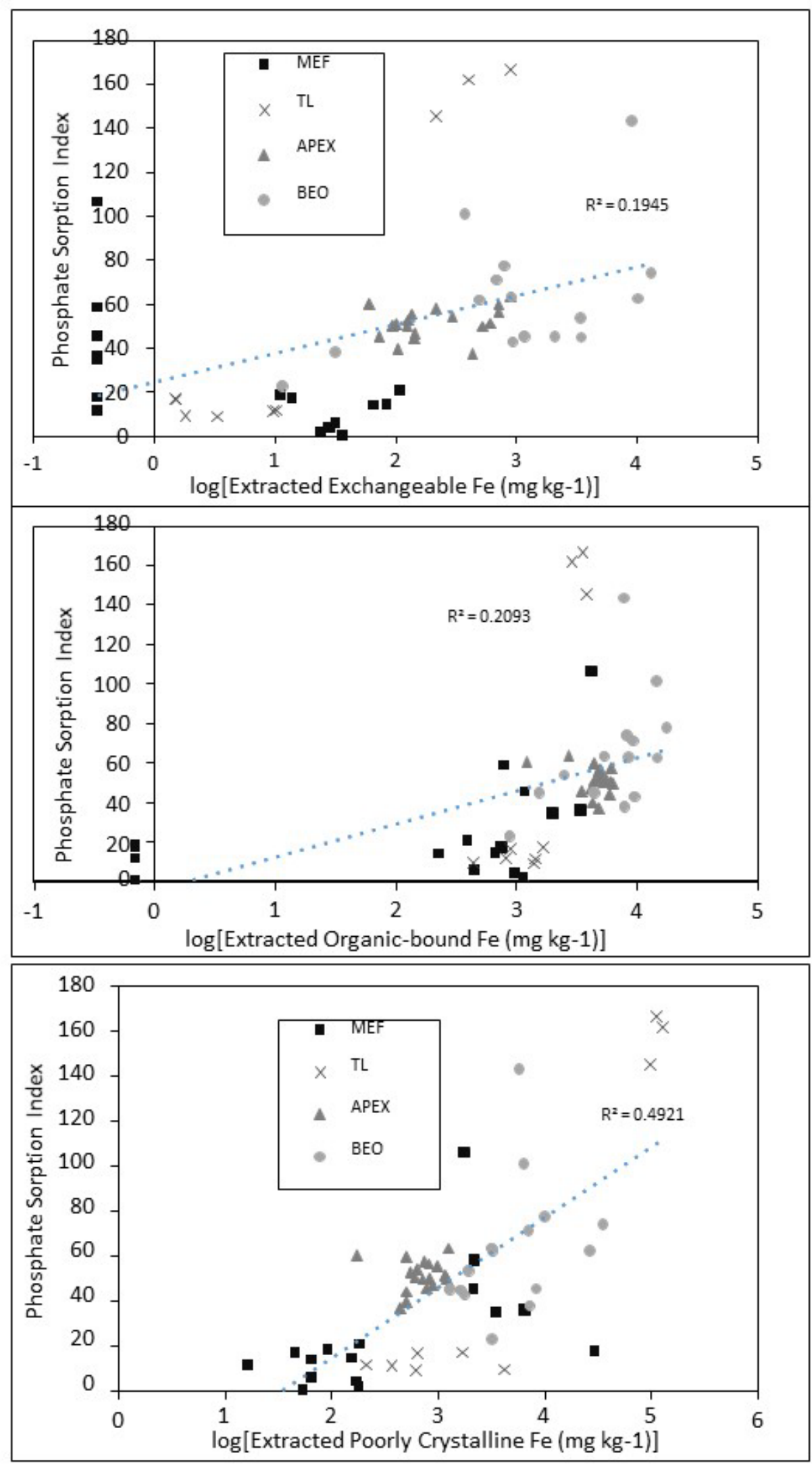


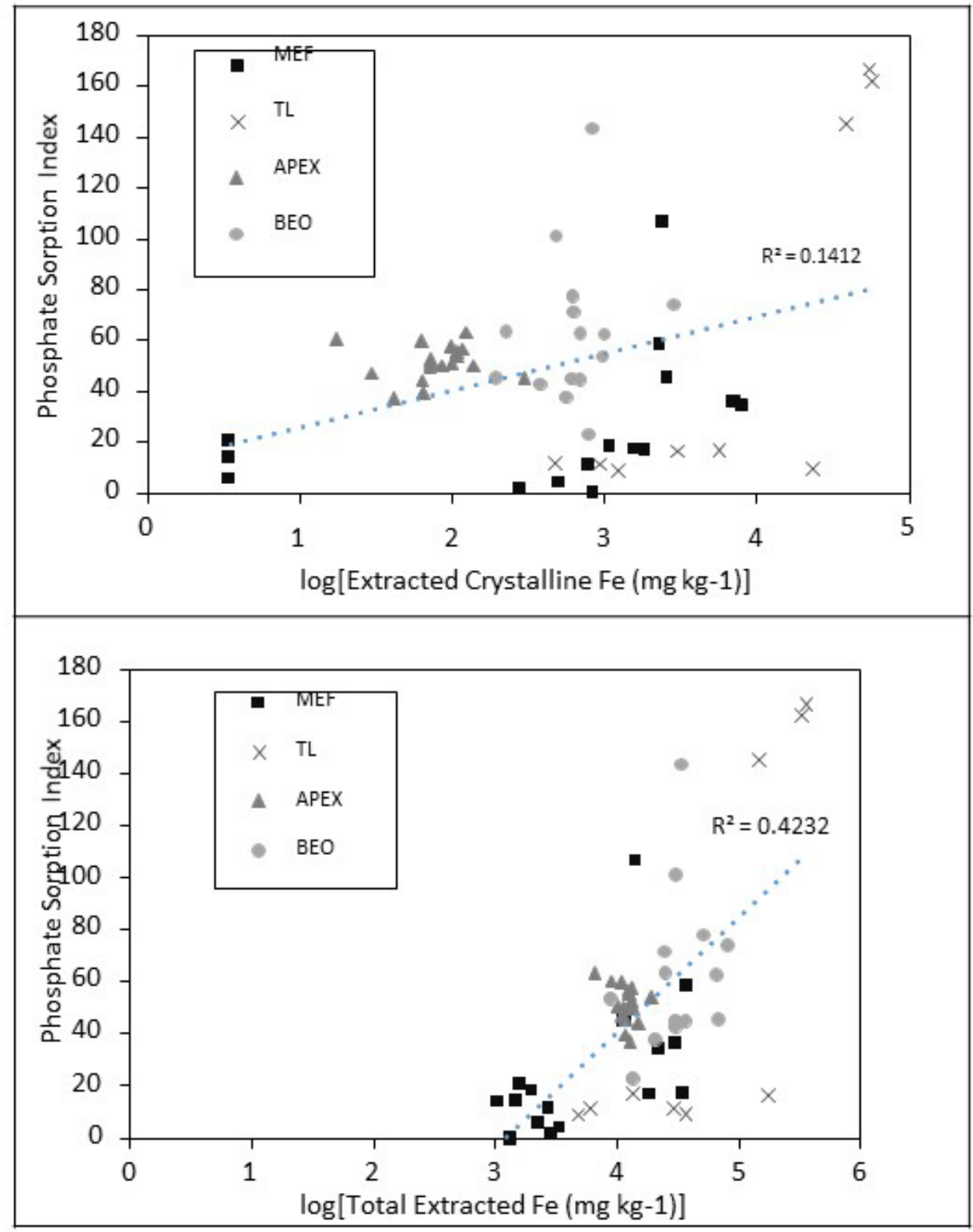

Figure 23: Positive correlations were observed between PSI and exchangeable Fe, organic-bound $\mathrm{Fe}$, poorly crystalline and crystalline Fe. The graphs were constructed with extracted Fe on a log axis for a clearer visual representation. The strongest relationship was observed between poorlycrystalline iron and PSI $\left(\mathrm{R}^{2}=0.49\right)$. 


\section{Tables}

Table 1: A total of 15 soil cores were collected with three replicates from each topographic feature at the Barrow Environmental Observatory. The average core length for all 15 cores was $21.6 \mathrm{~cm}( \pm 5.31)$. The average depth to organic-mineral horizon was $11.1 \mathrm{~cm}( \pm 2.73)$.

\begin{tabular}{|c|c|c|c|}
\hline Sample ID & Replicate & $\begin{array}{c}\text { Total Core Length } \\
\mathrm{cm}\end{array}$ & $\begin{array}{c}\text { Organic Horizon Depth } \\
\mathrm{cm}\end{array}$ \\
\hline \multirow{3}{*}{ BEO_LCP-Ridge } & 1 & 19 & 8 \\
& 2 & 21 & 7 \\
& 3 & 19 & 8 \\
BEO_LCP-Center & 1 & 13 & 13 \\
& 2 & 12 & 12 \\
& 3 & 17 & 17 \\
BEO_LCP-Trough & 1 & 20 & 12 \\
& 2 & 20 & 12 \\
& 3 & 21 & 12 \\
BEO_HCP-Center & 1 & 29.5 & 12 \\
& 2 & 26.5 & 8 \\
& 3 & 29 & 12 \\
\hline \multirow{3}{*}{ BEO_HCP-Trough } & 1 & 24.5 & 13 \\
& 2 & 26.5 & 12.5 \\
\hline
\end{tabular}


Table 2: The sequential extraction has been modified from Amacher et al. (1990), Siregar et al. (2005), Tessier et al. (1979), and Poulton and Canfield (2005) for use on peat soils by includinga step for removal of organic matter.

\begin{tabular}{|c|c|c|c|}
\hline & Fe-Fraction & Reagent & Reference \\
\hline 1 & Exchangeable & $0.1 \mathrm{M} \mathrm{BaCl}_{2}-\mathrm{NH}_{4} \mathrm{Cl}$ & Amacher et al. 1990 \\
\hline 2 & Organic-bound & $6 \%$ Sodium hypochlorite & Siregar et al. 2005 \\
\hline 3 & Poorly-crystalline oxides & $\begin{array}{l}\text { 1M Hydroxylamine- } \mathrm{HCl} \text { in } 25 \% \\
\text { v/v Acetic acid }\end{array}$ & $\begin{array}{c}\text { Poulten \& Canfield, } \\
2004\end{array}$ \\
\hline 4 & Crystalline oxides & $\begin{array}{l}50 \mathrm{~g} / \mathrm{L} \text { Sodium dithionite in } 0.35 \\
\mathrm{M} \text { Acetic acid/0.2 M sodium } \\
\text { citrate buffer }\end{array}$ & $\begin{array}{c}\text { Poulten \& Canfield, } \\
2004\end{array}$ \\
\hline 5 & Magnetite & $\begin{array}{l}0.2 \mathrm{M} \text { Ammonium oxalate/0.17 } \\
\text { M Oxalic acid }\end{array}$ & $\begin{array}{c}\text { Poulten \& Canfield, } \\
2004\end{array}$ \\
\hline
\end{tabular}


Table 3: Site summary for sequential iron extraction results. Results are presented as $\mu \mathrm{g} \mathrm{g}^{-1}$ of dry soil.

\begin{tabular}{|c|c|c|c|c|c|c|}
\hline & $\begin{array}{c}\text { Total } \\
\text { Average } \\
\text { Extracted } \\
\text { Fe } \\
\mu \mathrm{g} \mathrm{g}^{-1}\end{array}$ & $\begin{array}{l}\text { Fe Exch }^{\sim} \\
\mu \mathrm{g} \mathrm{g}^{-1}(\%)\end{array}$ & $\begin{array}{l}\mathrm{Fe}^{\sim} \mathrm{Org} \\
\mu \mathrm{g} \mathrm{g}^{-1}(\%)\end{array}$ & $\begin{array}{c}F^{\sim} \sim \mathrm{PXL} \\
\mu \mathrm{g} \mathrm{g}^{-1}(\%)\end{array}$ & $\begin{array}{c}F^{\sim} X^{\prime} \\
\mu g^{-1}(\%)\end{array}$ & $\begin{array}{l}\mathrm{Fe}^{\sim M a g} \\
\mu \mathrm{g} \mathrm{g}^{-1}(\%)\end{array}$ \\
\hline \multicolumn{7}{|c|}{ Barrow Environmental Observatory } \\
\hline $\begin{array}{l}\text { Average } \\
\text { std.err. }\end{array}$ & $\begin{array}{l}15,210 \\
1,173\end{array}$ & $\begin{array}{c}2,517 \\
(16.5 \%) \\
673\end{array}$ & $\begin{array}{c}5,430(35.7 \%) \\
890\end{array}$ & $\begin{array}{c}6,096(40.1 \%) \\
1,491\end{array}$ & $\begin{array}{c}807(5.3 \%) \\
114\end{array}$ & $\begin{array}{c}359(2.4 \%) \\
66\end{array}$ \\
\hline \multicolumn{7}{|c|}{ Toolik Field Station } \\
\hline Average & 60,797 & $171(0.28 \%)$ & 1,866 (3.1\%) & 3,8076 (62.6\%) & 20,364 (33.5\%) & $320(0.53 \%)$ \\
\hline std.err. & 7,513 & 101 & 408 & 18,566 & 7,849 & 101 \\
\hline \multicolumn{7}{|c|}{ Alaskan Peatland Experiment } \\
\hline Average & 5,829 & $307(5.3 \%)$ & $4,652(79.8 \%)$ & 734 (12.6\%) & 93 (1.6\%) & $43(0.74 \%)$ \\
\hline std.err. & 880 & 63 & 295 & 67 & 14 & 3 \\
\hline \multicolumn{7}{|c|}{ Marcell Experimental Forest } \\
\hline Average & 5,794 & $26(0.44 \%)$ & 1,005 (17.3\%) & 2,923 (50.4\%) & 1,813 (31.3\%) & $27(0.47 \%)$ \\
\hline std.err. & 553 & 8 & 302 & 1,838 & 593 & 6 \\
\hline \multicolumn{7}{|c|}{ All Sites } \\
\hline Average & 21,907 & $1,035(6.3 \%)$ & $3,760(22.8 \%)$ & 8,103 (49.2\%) & 3,367 (20.5\%) & $197(1.2 \%)$ \\
\hline std.err. & 705 & 286 & 422 & 2,760 & 1,249 & 34 \\
\hline
\end{tabular}


Table 4: Site comparison for soil characteristics including $\mathrm{pH}$, water content, organic content (as loss on ignition) and phosphate sorption index.

\begin{tabular}{|c|c|c|c|c|}
\hline & $\mathrm{pH}_{\mathrm{KCl}}$ & $\begin{array}{l}\text { Water Content } \\
\mathrm{g} \mathrm{H}_{2} \mathrm{O} \text { g soil }^{-1}\end{array}$ & $\begin{array}{c}\text { Organic Content } \\
\text { LOI \% }\end{array}$ & $\begin{array}{c}\text { Phosphate } \\
\text { Sorption Index }\end{array}$ \\
\hline \multicolumn{5}{|c|}{ Barrow Environmental Observatory } \\
\hline Average & 4.45 & 2.66 & 67.0 & 53.0 \\
\hline std.err. & 0.12 & 0.67 & 6.04 & 3.73 \\
\hline \multicolumn{5}{|c|}{ Toolik Field Station } \\
\hline Average & 5.52 & 3.33 & 63.8 & 61.1 \\
\hline std.err. & 0.20 & 1.67 & 7.39 & 6.98 \\
\hline \multicolumn{5}{|c|}{ Alaskan Peatland Experiment } \\
\hline Average & 4.53 & 4.91 & 81.9 & 51.4 \\
\hline std.err. & 0.04 & 0.69 & 0.88 & 1.24 \\
\hline \multicolumn{5}{|c|}{ Marcell Experimental Forest } \\
\hline Average & 4.23 & 8.57 & 90.1 & 25.2 \\
\hline std.err. & 0.42 & 1.11 & 1.57 & 4.44 \\
\hline \multicolumn{5}{|c|}{ All Sites } \\
\hline Average & 4.58 & 4.79 & 77.4 & 46.9 \\
\hline std.err. & 0.13 & 0.65 & 2.42 & 2.96 \\
\hline
\end{tabular}


Table 5: Site summary for soil characteristics including $\mathrm{pH}$, water content, organic content (as loss on ignition) for Barrow Environmental Observatory.

\begin{tabular}{|c|c|c|c|c|c|}
\hline Sample ID & $\begin{array}{c}\text { Depth } \\
\text { cm }\end{array}$ & Soil Horizon & $\mathrm{pH}_{\mathrm{KCl}}$ & $\begin{array}{l}\text { Water Content } \\
\mathrm{g} \mathrm{H}_{2} \mathrm{O} \text { g soil }^{-1}\end{array}$ & $\begin{array}{c}\text { Organic } \\
\text { Content } \\
\text { LOI } \%\end{array}$ \\
\hline BEO_LCP-Ridge-O & $0-8$ & Organic & 4.06 & 3.98 & 90 \\
\hline BEO_LCP-Ridge-M & $8-20$ & Mineral & 4.12 & 0.92 & 33 \\
\hline BEO_LCP-Center-O & $0-14$ & Organic & 4.36 & 2.38 & 48 \\
\hline BEO_LCP-Trough-O & $0-12$ & Organic & 4.90 & 5.82 & 57 \\
\hline BEO_LCP-Trough-M & $12-20$ & Mineral & 4.85 & 1.21 & 27 \\
\hline BEO_HCP-Center-O & $0-11$ & Organic & 3.93 & 2.25 & 22 \\
\hline BEO_HCP-Center-M & $11-28$ & Mineral & 4.20 & 0.52 & 28 \\
\hline BEO_HCP-Trough-O & $0-11$ & Organic & 4.98 & 5.23 & 65 \\
\hline BEO_HCP-Trough-M & $11-26$ & Mineral & 5.09 & 1.65 & 38 \\
\hline \multicolumn{3}{|c|}{ Organic, average } & 4.44 & 3.93 & 56 \\
\hline \multicolumn{3}{|c|}{ Organic, std.err. } & 0.09 & 0.72 & 11 \\
\hline \multicolumn{3}{|c|}{ Mineral, average } & 4.55 & 1.08 & 32 \\
\hline \multicolumn{3}{|c|}{ Mineral, std.err. } & 0.09 & 0.24 & 2.5 \\
\hline \multicolumn{3}{|c|}{ Low-Centered Polygon, average } & 4.44 & 2.86 & 51 \\
\hline \multicolumn{3}{|c|}{$L C P$, std.err. } & 0.08 & 0.91 & 11 \\
\hline \multicolumn{3}{|c|}{ High-Centered Polygon, average } & 4.55 & 2.41 & 38 \\
\hline \multicolumn{3}{|c|}{ HCP, std.err. } & 0.1 & 1 & 9.5 \\
\hline \multicolumn{3}{|c|}{ Low-Centered Polygon Organic, average } & 4.43 & 4.06 & 65 \\
\hline \multicolumn{3}{|c|}{ LCP-Organic, std.err. } & 0.11 & 0.99 & 13 \\
\hline \multicolumn{3}{|c|}{ High-Centered Polygon Organic, average } & 4.45 & 3.74 & 44 \\
\hline \multicolumn{3}{|c|}{ HCP-Organic, std.err. } & 0.13 & 1.49 & 22 \\
\hline
\end{tabular}


Table 6: Site summary for sequential iron extraction results from Barrow Environmental Observatory. Results are presented as $\mu \mathrm{g} \mathrm{g}^{-1}$ of dry soil.

\begin{tabular}{|c|c|c|c|c|c|c|c|c|}
\hline Sample ID & $\begin{array}{l}\text { Depth } \\
\text { cm }\end{array}$ & $\begin{array}{c}\text { Soil } \\
\text { Horizon }\end{array}$ & $\begin{array}{c}\text { Total Fe } \\
\text { Extracted } \\
{\mu \mathrm{g} \mathrm{g}^{-1}}\end{array}$ & $\begin{array}{l}\mathrm{Fe}^{\sim} \mathrm{Exch} \\
\mu \mathrm{g} \mathrm{g}^{-1}(\%)\end{array}$ & $\begin{array}{c}\mathrm{Fe}^{\sim} \mathrm{Org} \\
\mu \mathrm{g} \mathrm{g}^{-1}(\%)\end{array}$ & $\begin{array}{c}F e^{\sim P X L} \\
\mu g^{-1}(\%)\end{array}$ & $\begin{array}{c}F e^{\sim X L} \\
\mu g^{-1}(\%)\end{array}$ & $\begin{array}{c}\mathrm{Fe}^{\sim M a g} \\
\mu \mathrm{g} \mathrm{g}^{-1}(\%)\end{array}$ \\
\hline BEO_LCP-Ridge-O & $0-8$ & Organic & 31,450 & 559 (1.8\%) & $\begin{array}{c}15,714 \\
\mathbf{( 5 0 \% )}\end{array}$ & 14,459 (46\%) & 705 (2.2\%) & $1.4(0.0 \%)$ \\
\hline BEO_LCP-Ridge-M & $8-20$ & Mineral & 8,619 & 95 (1.1\%) & 3,865 (45\%) & 3,505 (41\%) & 607 (7.0\%) & 547 (6.3\%) \\
\hline BEO_LCP-Center-O & $0-14$ & Organic & 10,849 & 1,855 (17\%) & 3,732 (34\%) & 4,395 (41\%) & 511 (4.7\%) & $356(3.3 \%)$ \\
\hline BEO_LCP-Trough-O & $0-12$ & Organic & 20,851 & $9,740(47 \%)$ & 6,321 (30\%) & 3,670 (18\%) & 841 (4.0\%) & 280 (1.3\%) \\
\hline BEO_LCP-Trough-M & $12-20$ & Mineral & 8,219 & $3,889(47 \%)$ & 1,231 (15\%) & 1,961 (24\%) & 721 (8.8\%) & 418 (5.1\%) \\
\hline BEO_HCP-Center-O & $0-11$ & Organic & 11,294 & 325 (2.9\%) & 6,070 (54\%) & 4,085 (36\%) & 576 (5.1\%) & $238(2.1 \%)$ \\
\hline BEO_HCP-Center-M & $11-28$ & Mineral & 7,057 & 429 (6.1\%) & 1,889 (27\%) & 3,428 (49\%) & 811 (11\%) & 500 (7.1\%) \\
\hline BEO_HCP-Trough-O & $0-11$ & Organic & 28,879 & 5,303 (18\%) & 7,318 (25\%) & 14,727 (51\%) & 1,231 (4.3\%) & 229 (1.0\%) \\
\hline BEO_HCP-Trough-M & $11-26$ & Mineral & 12,253 & 3,042 (25\%) & 2,727 (22\%) & 4,639 (38\%) & 1,263 (10\%) & 582 (4.8\%) \\
\hline \multicolumn{3}{|c|}{ Organic, average } & 20,223 & 3,115 (15\%) & 7,831 (39\%) & 8,267 (41\%) & 773 (3.8\%) & $238(1.2 \%)$ \\
\hline \multicolumn{3}{|c|}{ Organic, std.err. } & & 1,127 & 1,282 & 2,550 & 162 & 73 \\
\hline \multicolumn{3}{|c|}{ Mineral, average } & 8,930 & $1,757(20 \%)$ & $2,428(27 \%)$ & 3,383 (38\%) & 851 (9.5\%) & $512(5.7 \%)$ \\
\hline \multicolumn{3}{|c|}{ Mineral, std.err. } & & 534 & 348 & 511 & 164 & 723 \\
\hline \multicolumn{3}{|c|}{ Low-Centered Polygon, average } & 15,533 & $2,762(18 \%)$ & $6,173(40 \%)$ & $5,598(36 \%)$ & 677 (4.4\%) & $323(2.1 \%)$ \\
\hline \multicolumn{3}{|c|}{$L C P$, std.err. } & & 870 & 1,411 & 1,655 & 63 & 92 \\
\hline \multicolumn{3}{|c|}{ High-Centered Polygon, average } & 14,801 & 2,205 (15\%) & 4,501 (30\%) & $6,720(45 \%)$ & 970 (6.6\%) & 405 (2.7\%) \\
\hline \multicolumn{3}{|c|}{$H C P$, std.err. } & & 1,096 & 949 & 2,719 & 241 & 98 \\
\hline \multicolumn{3}{|c|}{ Low-Centered Polygon Organic, average } & 20,339 & $3,340(16 \%)$ & 8,589 (42\%) & 7,508 (37\%) & 685 (3.4\%) & 217 (1.1\%) \\
\hline \multicolumn{3}{|c|}{ LCP-Organic, std.err. } & 3,434 & 1,360 & 1,954 & 2,599 & 81 & 102 \\
\hline \multicolumn{3}{|c|}{$\begin{array}{l}\text { High-Centered Polygon Organic, } \\
\text { average }\end{array}$} & 20,086 & 2,814 (14\%) & 6,694 (33\%) & 9,406 (47\%) & 903 (4.5\%) & 269 (1.3\%) \\
\hline \multicolumn{3}{|c|}{ HCP-Organic, std.err. } & 5,076 & 2,084 & 1,382 & 5,375 & 403 & 112 \\
\hline
\end{tabular}


Table 7: Site summary for soil characteristics including $\mathrm{pH}$, water content, organic content (as loss on ignition) for Toolik Lake Field Station.

\begin{tabular}{|c|c|c|c|c|}
\hline Sample ID & $\begin{array}{c}\text { Topographic } \\
\text { Position }\end{array}$ & $\mathrm{pH}_{\mathrm{KCl}}$ & $\begin{array}{l}\text { Water Content } \\
\qquad \mathrm{g} \mathrm{H}_{2} \mathrm{O} \text { g soil }^{-1}\end{array}$ & $\begin{array}{c}\text { Organic Content } \\
\text { LOI \% }\end{array}$ \\
\hline TL_Site1-T & Heath & 5.40 & 3.13 & 89 \\
\hline \multicolumn{2}{|c|}{ Heath, std.err. } & 0.05 & 0.15 & 0.71 \\
\hline TL_Site2-H & Tussock Tundra & 4.99 & 0.56 & 44 \\
\hline \multicolumn{2}{|c|}{ Tussock Tundra, std.err. } & 0.24 & 0.05 & 11.5 \\
\hline TL_Site3-WS & Wet sedge & 6.16 & 6.32 & 58 \\
\hline \multicolumn{2}{|c|}{ Wet sedge, std.err. } & 0.07 & 0.15 & 0.81 \\
\hline
\end{tabular}


Table 8: Site summary for sequential iron extraction results from Toolik Lake Field Station. Results are presented as $\mu \mathrm{g}$ g- 1 of dry soil.

\begin{tabular}{|c|c|c|c|c|c|c|c|}
\hline Sample ID & $\begin{array}{l}\text { Topographic } \\
\text { Position }\end{array}$ & $\begin{array}{c}\text { Total Fe } \\
\text { Extracted } \\
{\mu g^{-1}}^{-1}\end{array}$ & $\begin{array}{l}\mathrm{Fe}^{\sim} \text { Exch } \\
\mu \mathrm{g} \mathrm{g}^{-1}(\%)\end{array}$ & $\begin{array}{l}\mathrm{Fe}^{\sim O} \mathrm{Org} \\
\mu \mathrm{g} \mathrm{g}^{-1}(\%)\end{array}$ & $\begin{array}{l}F e^{\sim P X L} \\
\mu g^{-1}(\%)\end{array}$ & $\begin{array}{c}F e^{\sim X L} \\
\mu g^{-1}(\%)\end{array}$ & $\begin{array}{l}F^{\sim} \text { Mag } \\
\mu \mathrm{g} \mathrm{g}^{-1}(\%)\end{array}$ \\
\hline TL_Site1-T & Heath & 2,562 & $\begin{array}{c}7.7 \\
(0.3 \%)\end{array}$ & 1,211 (47\%) & 396 (15\%) & $873(34 \%)$ & $74(2.9 \%)$ \\
\hline \multicolumn{2}{|c|}{ Heath, std.err. } & 232 & 2.3 & 199 & 30 & 218 & 16 \\
\hline TL_Site2-H & Tussock Tundra & 14,206 & $\begin{array}{c}2.0 \\
(0.0 \%)\end{array}$ & 996 (7\%) & 2,162 (15\%) & 10,588 (75\%) & 457 (3.2\%) \\
\hline \multicolumn{2}{|c|}{ Tussock tundra, std.err. } & 1,970 & 0.0 & 357 & 66 & 7,741 & 272 \\
\hline TL_Site3-WS & Wet sedge & 165,626 & $\begin{array}{c}504 \\
(0.3 \%)\end{array}$ & 3,391 (2.0\%) & 111,671 (67\%) & 49,630 (30\%) & $431(0.3 \%)$ \\
\hline \multicolumn{2}{|c|}{ Wet sedge, std.err. } & 21,747 & 201 & 168 & 30 & 5,774 & 41 \\
\hline
\end{tabular}


Table 9: Site summary for soil characteristics including $\mathrm{pH}$, water content, organic content (as loss on ignition) for the Alaskan Peatland Experiment site.

\begin{tabular}{|c|c|c|c|c|c|}
\hline Sample ID & $\begin{array}{c}\text { Depth } \\
\mathrm{cm}\end{array}$ & Soil Horizon & $\mathrm{pH}_{\mathrm{KCl}}$ & $\begin{array}{l}\text { Water Content } \\
\mathrm{g} \mathrm{H}_{2} \mathrm{O} \text { g soil }^{-1}\end{array}$ & $\begin{array}{c}\text { Organic Content } \\
\text { LOI \% }\end{array}$ \\
\hline APEX_Lowered-01 & $0-29$ & Organic 1 & 4.58 & 6.05 & 84 \\
\hline APEX_Lowered-02 & $29-57$ & Organic 2 & 4.34 & 3.41 & 81 \\
\hline APEX_Raised-01 & $0-34$ & Organic 1 & 4.82 & 6.93 & 88 \\
\hline APEX_Raised-O2 & $34-61$ & Organic 2 & 4.58 & 2.75 & 79 \\
\hline APEX_Control-O1 & $0-29$ & Organic 1 & 4.44 & 6.1 & 82 \\
\hline APEX_Control-O2 & 29-57 & Organic 2 & 4.42 & 4.2 & 80 \\
\hline \multicolumn{3}{|c|}{ Organic horizon 1, average } & 4.61 & 6.36 & 84 \\
\hline \multicolumn{3}{|c|}{ Organic 1, std.err. } & 0.05 & 0.45 & 1.0 \\
\hline \multicolumn{3}{|c|}{ Organic horizon 2, average } & 4.45 & 3.45 & 80 \\
\hline \multicolumn{3}{|c|}{ Organic 2, std.err. } & 0.04 & 0.46 & 1.0 \\
\hline \multicolumn{3}{|c|}{ Lowered plot, average } & 4.46 & 4.73 & 83 \\
\hline \multicolumn{3}{|c|}{ Lowered, std.err. } & 0.03 & 1.32 & 1.3 \\
\hline \multicolumn{3}{|c|}{ Raised plot, average } & 4.7 & 4.84 & 82 \\
\hline \multicolumn{3}{|c|}{ Raised, std.err. } & 0.05 & 2.09 & 1.7 \\
\hline \multicolumn{3}{|c|}{ Control plot, average } & 4.43 & 5.15 & 81 \\
\hline \multicolumn{3}{|c|}{ Control, std.err. } & 0.06 & 0.95 & 1.8 \\
\hline \multicolumn{3}{|c|}{ Control, Lowered, Raised plot, average } & 4.53 & 4.91 & 82 \\
\hline \multicolumn{3}{|c|}{ std.err. } & 0.08 & 0.69 & 1.3 \\
\hline
\end{tabular}


Table 10: Site summary for sequential iron extraction results from the Alaskan Peatland Experiment site. Results are presented as $\mu \mathrm{g} \mathrm{g}^{-1}$ of dry soil.

\begin{tabular}{|c|c|c|c|c|c|c|c|c|}
\hline Sample ID & $\begin{array}{c}\text { Depth } \\
\text { cm }\end{array}$ & $\begin{array}{c}\text { Soil } \\
\text { Horizon }\end{array}$ & $\begin{array}{c}\text { Total Fe } \\
\text { Extracted } \\
\mu \mathrm{g} \mathrm{g}^{-1}\end{array}$ & $\begin{array}{l}F^{\sim} \text { Exch } \\
\mu g^{-1}(\%)\end{array}$ & $\begin{array}{l}\text { Fe Org }^{\sim} \\
\mu \mathrm{g} \mathrm{g}^{-1}(\%)\end{array}$ & $\begin{array}{l}F e^{\sim P X L} \\
\mu g^{-1}(\%)\end{array}$ & $\begin{array}{c}\mathrm{Fe}^{\sim} \mathrm{XL} \\
\mu \mathrm{g} \mathrm{g}^{-1}(\%)\end{array}$ & $\begin{array}{c}\mathrm{Fe}^{\sim M a g} \\
\mu \mathrm{g} \mathrm{g}^{-1}(\%)\end{array}$ \\
\hline APEX_Lowered-O1 & $0-29$ & Organic 1 & 7,092 & 249 (3.5\%) & $5,792(82 \%)$ & 907 (13\%) & 98 (1.4\%) & $46(0.6 \%)$ \\
\hline APEX_Lowered-O2 & $29-57$ & Organic 2 & 5,274 & $104(2.0 \%)$ & 4,187 (79\%) & $782(15 \%)$ & 159 (3.0\%) & $42(0.8 \%)$ \\
\hline APEX_Raised-O1 & $0-34$ & Organic 1 & 5,899 & 547 (9.3\%) & 4,135 (70\%) & 1,100 (19\%) & $84(1.4 \%)$ & $34(0.6 \%)$ \\
\hline APEX_Raised-O2 & $34-61$ & Organic 2 & 4,272 & 302 (7.1\%) & $3,482(82 \%)$ & 405 (9.5\%) & $51(1.2 \%)$ & $31(0.7 \%)$ \\
\hline APEX_Control-O1 & $0-29$ & Organic 1 & 5,825 & 229 (3.9\%) & $5,004(86 \%)$ & 479 (8.2\%) & $57(1.0 \%)$ & $57(1.0 \%)$ \\
\hline APEX_Control-O2 & $29-57$ & Organic 2 & 6,608 & $410(6.2 \%)$ & $5,314(80 \%)$ & 729 (11\%) & 107 (1.6\%) & $48(0.7 \%)$ \\
\hline \multicolumn{3}{|c|}{ Organic horizon 1, average } & 5,658 & $307(5.4 \%)$ & $4,479(79 \%)$ & 746 (13\%) & 79 (1.4\%) & $46(0.8 \%)$ \\
\hline \multicolumn{3}{|c|}{ Organic 1, std.err. } & & 95 & 375 & 106 & 25 & 4.1 \\
\hline \multicolumn{3}{|c|}{ Organic horizon 2, average } & 5,385 & $272(5.1 \%)$ & $4,328(80 \%)$ & $639(\mathbf{1 2 \%})$ & $106(2.0 \%)$ & $40(0.8 \%)$ \\
\hline \multicolumn{3}{|c|}{ Organic 2, std.err. } & & 87 & 450 & 76 & 26 & 4.8 \\
\hline \multicolumn{3}{|c|}{ Lowered plot, average } & 6,183 & $177(2.9 \%)$ & $4,990(81 \%)$ & $845(14 \%)$ & 129 (2.1\%) & $44(0.7 \%)$ \\
\hline \multicolumn{3}{|c|}{ Lowered, std.err. } & & 71 & 425 & 86 & 35 & 3.2 \\
\hline \multicolumn{3}{|c|}{ Raised plot, average } & 5,086 & $424(8.3 \%)$ & 3,809 (75\%) & 753 (15\%) & $68(1.3 \%)$ & $33(0.6 \%)$ \\
\hline \multicolumn{3}{|c|}{ Raised, std.err. } & & 145 & 641 & 172 & 16 & 6.4 \\
\hline \multicolumn{3}{|c|}{ Control plot, average } & 6,217 & $320(5.1 \%)$ & $5,159(83 \%)$ & $604(10 \%)$ & $82(1.3 \%)$ & $53(0.8 \%)$ \\
\hline \multicolumn{3}{|c|}{ Control, std.err. } & & 93 & 281 & 61 & 12 & 3.0 \\
\hline \multicolumn{3}{|c|}{ Control, Lowered, Raised plot, average } & 5,829 & $307(5.3 \%)$ & $4,652(80 \%)$ & 734 (13\%) & 93 (1.6\%) & $43(0.7 \%)$ \\
\hline \multicolumn{3}{|c|}{ std.err. } & 234 & 36 & 75 & 61 & 9.3 & 2.2 \\
\hline
\end{tabular}


Table 11: Site summary for soil characteristics including $\mathrm{pH}$, water content, organic content (as loss on ignition) for Marcell Experimental Forest.

\begin{tabular}{|c|c|c|c|c|}
\hline Sample ID & $\begin{array}{l}\text { Topographic } \\
\text { Feature }\end{array}$ & $\mathrm{pH}_{\mathrm{KCl}}$ & $\begin{array}{l}\text { Water Content } \\
\mathrm{g} \mathrm{H}_{2} \mathrm{O} \text { g soil }^{-1}\end{array}$ & $\begin{array}{c}\text { Organic Content } \\
\text { LOI \% }\end{array}$ \\
\hline MEF_Site1-Hk & Hummock & 2.96 & 7.62 & 98 \\
\hline MEF_Site1-Hw & Hollow & 3.05 & 13.73 & 92 \\
\hline MEF_Site2-Hk & Hummock & 3.01 & 6.69 & 97 \\
\hline MEF_Site2-Hw & Hollow & 2.90 & 6.14 & 92 \\
\hline MEF_Site3-Hk & Hummock & 6.40 & 8.99 & 81 \\
\hline MEF_Site3-Hw & Hollow & 6.19 & 8.26 & 86 \\
\hline \multicolumn{2}{|c|}{ Hummock, average } & 4.45 & 7.75 & 90 \\
\hline \multicolumn{2}{|c|}{ Hummock, std.err. } & 0.47 & 0.75 & 3.4 \\
\hline \multicolumn{2}{|c|}{ Hollow, average } & 4.05 & 9.38 & 90 \\
\hline \multicolumn{2}{|c|}{ Hollow, std.err. } & 0.42 & 1.18 & 2.8 \\
\hline \multicolumn{2}{|c|}{ Site 1 Bog, average } & 3.03 & 12.21 & 93 \\
\hline \multicolumn{2}{|c|}{ Site 1 Bog, std.err. } & 0.59 & 1.65 & 3.1 \\
\hline \multicolumn{2}{|c|}{ Site 2 Bog, average } & 2.95 & 6.34 & 94 \\
\hline \multicolumn{2}{|c|}{ Site 2 Bog, std.err. } & 0.46 & 0.35 & 1.3 \\
\hline \multicolumn{2}{|c|}{ Site 1 and 2 Bog, average } & 2.98 & 8.55 & 95 \\
\hline \multicolumn{2}{|c|}{ Site 1 and 2 Bog, std.err. } & 0.03 & 1.76 & 3.2 \\
\hline \multicolumn{2}{|c|}{ Site 3 Fen, average } & 6.29 & 8.62 & 84 \\
\hline \multicolumn{2}{|c|}{ Site 3 Fen, std.err. } & 0.45 & 0.71 & 1.7 \\
\hline
\end{tabular}


Table 12: Site summary for sequential iron extraction results from the Marcell Experimental Forest. Results are presented as $\mu \mathrm{g} \mathrm{g}^{-1}$ of dry soil.

\begin{tabular}{|c|c|c|c|c|c|c|c|}
\hline Sample ID & $\begin{array}{c}\text { Topographic } \\
\text { Feature }\end{array}$ & $\begin{array}{c}\text { Total Fe } \\
\text { Extracted } \\
\mu \mathrm{g} \mathrm{g}^{-1}\end{array}$ & $\begin{array}{l}F^{\sim} \text { Exch } \\
\mu g^{-1}(\%)\end{array}$ & $\begin{array}{l}\text { Fe Org } \\
\mu \mathrm{g} \mathrm{g}^{-1}(\%)\end{array}$ & $\begin{array}{l}F e^{\sim P X L} \\
\mu g^{-1}(\%)\end{array}$ & $\begin{array}{c}F^{\sim} \mathbf{X} \\
\mu g^{-1}(\%)\end{array}$ & $\begin{array}{c}\mathrm{Fe}^{\sim \mathrm{Mag}} \\
\mu \mathrm{g} \mathrm{g}^{-1}(\%)\end{array}$ \\
\hline MEF_S1Hk & Hummock & 960 & 37 (3.9\%) & $<1.4$ & 54 (5.6\%) & 841 (88\%) & $28(2.9 \%)$ \\
\hline MEF_S1Hw & Hollow & 654 & 87 (13\%) & $443(66 \%)$ & $134(20 \%)$ & $<6.9$ & $<0.69$ \\
\hline MEF_S2Hk & Hummock & 1,330 & $8.4(0.6 \%)$ & $<1.4$ & 51 (3.9\%) & 1,235 (93\%) & 35 (12.6\%) \\
\hline MEF_S2Hw & Hollow & 1,294 & $28(2.2 \%)$ & $858(66 \%)$ & 139 (11\%) & $258(20 \%)$ & $10(0.8 \%)$ \\
\hline MEF_S3Hk & Hummock & 14,428 & $<0.69$ & 906 (6.3\%) & 11,332 (79\%) & 2,145 (15\%) & $46(0.3 \%)$ \\
\hline MEF_S3Hw & Hollow & 12,866 & $<0.69$ & 3,160 (25\%) & 3,913 (30\%) & $5,747(45 \%)$ & $46(0.4 \%)$ \\
\hline \multicolumn{2}{|c|}{ Hummock, average } & 1378 & $9.1(0.1 \%)$ & 389 (5.6\%) & 4,886 (71\%) & $1,569(23 \%)$ & 39 (0.6\%) \\
\hline \multicolumn{2}{|c|}{ Hummock, std.err. } & 779 & 5.1 & 190 & 266 & 266 & 5.8 \\
\hline \multicolumn{2}{|c|}{ Hollow, average } & 988 & $38(0.8 \%)$ & $1,484(30 \%)$ & 1,395 (28\%) & $2,003(41 \%)$ & $19(\mathbf{0 . 4 \% )}$ \\
\hline \multicolumn{2}{|c|}{ Hollow, std.err. } & 302 & 13 & 466 & 744 & 1058 & 8.2 \\
\hline \multicolumn{2}{|c|}{ Site 1 Bog, average } & 147 & 75 (10\%) & $325(44 \%)$ & 114 (16\%) & 213 (29\%) & 7.3 (1.0\%) \\
\hline \multicolumn{2}{|c|}{ Site 1 Bog, std.err. } & 62 & 15 & 142 & 32 & n.a. & n.a. \\
\hline \multicolumn{2}{|c|}{ Site 2 Bog, average } & 262 & $18(1.4 \%)$ & $429(33 \%)$ & 95 (7.3\%) & 747 (57\%) & $23(1.7 \%)$ \\
\hline \multicolumn{2}{|c|}{ Site 2 Bog, std.err. } & 130 & 4.9 & 213 & 28 & 267 & 6.5 \\
\hline \multicolumn{2}{|c|}{ Site 1 and 2 Bog, average } & 205 & 40 (3.9\%) & $377(37 \%)$ & $104(10 \%)$ & 479 (47\%) & 15 (1.5\%) \\
\hline \multicolumn{2}{|c|}{ Site 1 and 2 Bog, std.err. } & 26 & 3.05 & 52 & 9.3 & 267 & 7.7 \\
\hline \multicolumn{2}{|c|}{ Site 3 Fen, average } & 3412 & $<0.69$ & $2,033(15 \%)$ & 7,623 (56\%) & 3,946 (29\%) & $46(0.3 \%)$ \\
\hline \multicolumn{2}{|c|}{ Site 3 Fen, std.err. } & 1318 & n.a. & 581 & 4467 & 1115 & 8.4 \\
\hline
\end{tabular}


Appendices

Appendix I: Pore water chemistry results from the Alaskan Peatland Experiment.

\begin{tabular}{|c|c|c|c|c|c|c|c|}
\hline Sample ID & $\begin{array}{c}\text { Depth } \\
\text { cm }\end{array}$ & $\begin{array}{c}\text { Ti } \\
\mu \mathrm{g} / \mathrm{ml}\end{array}$ & $\begin{array}{c}\mathrm{Ca} \\
\mu \mathrm{g} / \mathrm{ml}\end{array}$ & $\begin{array}{c}\text { Al } \\
\mu \mathrm{g} / \mathrm{ml}\end{array}$ & $\begin{array}{c}\mathbf{P} \\
\mu \mathrm{g} / \mathrm{ml}\end{array}$ & $\begin{array}{c}\text { Fe } \\
\mu \mathrm{g} / \mathrm{ml}\end{array}$ & $\begin{array}{l}\text { Mn } \\
\mu \mathrm{g} / \mathrm{ml}\end{array}$ \\
\hline \multicolumn{8}{|c|}{ Lowered Plot } \\
\hline APEX_L-0 & 0 & $<\mathrm{DL}$ & 7.91 & 0.17 & 0.02 & 0.7 & 0.40 \\
\hline APEX_L-20 & 20 & $<\mathrm{DL}$ & 12.84 & 1.06 & 0.03 & 6.9 & 0.63 \\
\hline APEX_L-40 & 40 & $<\mathrm{DL}$ & 10.26 & 0.95 & 0.02 & 6.4 & 0.50 \\
\hline APEX_L-70 & 70 & $<\mathrm{DL}$ & 7.66 & 0.68 & 0.01 & 5.5 & 0.38 \\
\hline APEX_L-20d & 20 & $<\mathrm{DL}$ & 11.95 & 1.06 & 0.03 & 6.6 & 0.49 \\
\hline APEX_L-40d & 40 & $<\mathrm{DL}$ & 9.8 & 1.10 & 0.02 & 6.6 & 0.51 \\
\hline APEX_L-70d & 70 & $<\mathrm{DL}$ & 7.99 & 0.83 & 0.02 & 6.4 & 0.41 \\
\hline \multicolumn{8}{|c|}{ Raised Plot } \\
\hline APEX_R-0 & 0 & $<\mathrm{DL}$ & 6.92 & 0.22 & 0.01 & 2.1 & 0.89 \\
\hline APEX_R-20 & 20 & $<\mathrm{DL}$ & 8.36 & 0.44 & 0.02 & 4.6 & 0.48 \\
\hline APEX_R-40 & 40 & $<\mathrm{DL}$ & 8.98 & 0.86 & $<\mathrm{DL}$ & 6.4 & 0.53 \\
\hline APEX_R-70 & 70 & $<\mathrm{DL}$ & 10.09 & 0.88 & 0.04 & 6.5 & 0.59 \\
\hline APEX_R-20d & 20 & $<\mathrm{DL}$ & 9.91 & 0.54 & 0.04 & 6.1 & 0.51 \\
\hline APEX_R-40d & 40 & $<\mathrm{DL}$ & 9.89 & 0.93 & $<\mathrm{DL}$ & 6.6 & 0.55 \\
\hline APEX_R-70d & 70 & $<\mathrm{DL}$ & 9.27 & 0.73 & 0.03 & 6.7 & 0.47 \\
\hline \multicolumn{8}{|c|}{ Control Plot } \\
\hline APEX_C-0 & 0 & $<\mathrm{DL}$ & 10.22 & 0.21 & 0.02 & 1.5 & 0.52 \\
\hline APEX_C-20 & 20 & $<\mathrm{DL}$ & 12.72 & 0.88 & 0.04 & 8.7 & 0.53 \\
\hline APEX_C-40 & 40 & $<\mathrm{DL}$ & 13.62 & 1.28 & 0.02 & 10.1 & 0.59 \\
\hline APEX_C-70 & 70 & $<\mathrm{DL}$ & 10.49 & 0.69 & 0.02 & 8.3 & 0.49 \\
\hline APEX_C-20d & 20 & $<\mathrm{DL}$ & 11.18 & 0.77 & 0.03 & 7.0 & 0.42 \\
\hline APEX_C-40d & 40 & $<\mathrm{DL}$ & 10.27 & 1.06 & 0.02 & 6.9 & 0.58 \\
\hline APEX_C-70d & 70 & $<\mathrm{DL}$ & 6.59 & 0.71 & $<\mathrm{DL}$ & 5.6 & 0.40 \\
\hline
\end{tabular}




\section{Appendix II: Linear regression models.}

A. Phosphate Sorption Index versus Log Extracted Exchangeable Iron

\begin{tabular}{|l|r|}
\hline \begin{tabular}{l}
$\mid \begin{array}{l}\text { Regression } \\
\text { Statistics }\end{array}$ \\
\hline Multiple R
\end{tabular} \\
R Square & 0.440975 \\
Adjusted R Square & 0.194459 \\
Standard Error & 33.879265 \\
Observations & 58 \\
\hline
\end{tabular}

\begin{tabular}{|c|c|c|c|c|c|}
\hline ANOVA & & & & & \\
\hline & & $S S$ & $M S$ & $F$ & Sig. $F$ \\
\hline Regression & 1 & 15516.623 & 15516.623 & 13.51852 & 0.0005309 \\
\hline Residual & 56 & 64277.056 & 1147.8046 & & \\
\hline Total & 57 & 79793.679 & & & \\
\hline
\end{tabular}

\begin{tabular}{|r|rccccccc|}
\hline \multicolumn{2}{|c}{ Coefficients } & $\begin{array}{c}\text { Standard } \\
\text { Err. }\end{array}$ & $t$ Stat & P-value & $\begin{array}{c}\text { Lower } \\
95 \%\end{array}$ & $\begin{array}{c}\text { Upper } \\
95 \%\end{array}$ & $\begin{array}{c}\text { Lower } \\
95.0 \%\end{array}$ & $\begin{array}{c}\text { Upper } \\
95.0 \%\end{array}$ \\
\hline Intercept & 23.97555 & 8.056966 & 2.97575 & 0.00431 & 7.835506 & 40.115590 & 7.83551 & 40.11559 \\
X Variable 1 & 13.18369 & 3.585688 & 3.67675 & 0.00053 & 6.000698 & 20.366690 & 6.00070 & 20.36669 \\
\hline
\end{tabular}




\section{B. Phosphate Sorption Index versus Log Extracted Organic Bound Iron}

\begin{tabular}{|l|r|}
\hline $\begin{array}{l}|l| \\
\text { Regression } \\
\text { Statistics }\end{array}$ \\
\hline Multiple R & 0.457472 \\
R Square & 0.209281 \\
Adjusted R Square & 0.195161 \\
Standard Error & 33.566139 \\
Observations & 58 \\
\hline
\end{tabular}

\begin{tabular}{|c|c|c|c|c|c|c|c|c|}
\hline & \multicolumn{6}{|l|}{ ANOVA } & & \\
\hline & & $d f$ & SS & MS & $F$ & Sig. $F$ & & \\
\hline & $\begin{array}{r}\text { Regression } \\
\text { Residual } \\
\text { Total }\end{array}$ & $\begin{array}{r}1 \\
56 \\
57\end{array}$ & $\begin{array}{l}16699.282 \\
63094.397 \\
79793.679\end{array}$ & $\begin{array}{l}16699.282 \\
1126.6857\end{array}$ & 14.821598 & 0.0003057 & & \\
\hline & Coefficients & $\begin{array}{c}\text { Standard } \\
\text { Err. }\end{array}$ & t Stat & $P$-value & Lower 95\% & $\begin{array}{l}\text { Upper } \\
95 \%\end{array}$ & $\begin{array}{l}\text { Lower } \\
95.0 \% \\
\end{array}$ & $\begin{array}{l}\text { Upper } \\
95.0 \% \\
\end{array}$ \\
\hline Intercept & -5.36076 & 14.711230 & -0.36440 & 0.71693 & -34.830894 & 24.109375 & -34.83089 & 24.10937 \\
\hline $\mathrm{X}$ Variable 1 & 16.84337 & 4.375033 & 3.84988 & 0.00031 & 8.079121 & 25.607611 & 8.07912 & 25.60761 \\
\hline
\end{tabular}




\section{Phosphate Sorption Index versus Log Extracted Poorly Crystalline Iron}

\begin{tabular}{|l|r|}
\hline \multicolumn{2}{|l|}{$\begin{array}{l}\text { Regression } \\
\text { Statistics }\end{array}$} \\
\hline Multiple R & 0.701514 \\
R Square & 0.492122 \\
Adjusted R Square & 0.483052 \\
Standard Error & 26.901101 \\
Observations & 58 \\
\hline
\end{tabular}

\begin{tabular}{|c|c|c|c|c|c|}
\hline \multicolumn{6}{|l|}{ ANOVA } \\
\hline & $d f$ & SS & $M S$ & $F$ & Sig. $F$ \\
\hline Regression & 1 & 39268.203 & 39268.203 & 54.2626411 & $8.5846 \mathrm{E}-10$ \\
\hline Residual & 56 & 40525.476 & 723.66922 & & \\
\hline Total & 57 & 79793.679 & & & \\
\hline
\end{tabular}

\begin{tabular}{|c|c|c|c|c|c|c|c|c|}
\hline & Coefficients & $\begin{array}{c}\text { Standard } \\
\text { Err. }\end{array}$ & $t$ Stat & P-value & Lower 95\% & Upper 95\% & $\begin{array}{l}\text { Lower } \\
95.0 \%\end{array}$ & $\begin{array}{l}\text { Upper } \\
95.0 \%\end{array}$ \\
\hline Intercept & -47.70070 & 13.551632 & -3.51992 & 0.00087 & -74.847876 & -20.553515 & -74.84788 & -20.55351 \\
\hline X Variable 1 & 31.08958 & 4.220504 & 7.36632 & 0.00000 & 22.634891 & 39.544264 & 22.63489 & 39.54426 \\
\hline
\end{tabular}




\section{Phosphate Sorption Index versus Log Extracted Crystalline Iron}

\begin{tabular}{|l|r|}
\hline $\begin{array}{l}\text { Regression } \\
\text { Statistics }\end{array}$ \\
\hline Multiple R & 0.375731 \\
R Square & 0.141174 \\
Adjusted R Square & 0.125838 \\
Standard Error & 34.981855 \\
Observations & 58 \\
\hline
\end{tabular}

\begin{tabular}{|c|c|c|c|c|c|}
\hline \multicolumn{6}{|l|}{ ANOVA } \\
\hline & & SS & MS & $F$ & Sig. $F$ \\
\hline Regression & 1 & 11264.791 & 11264.791 & 9.205290133 & 0.003654869 \\
\hline Residual & 56 & 68528.888 & 1223.7301 & & \\
\hline Total & 57 & 79793.679 & & & \\
\hline
\end{tabular}

\begin{tabular}{|r|rccccccc|}
\hline \multicolumn{2}{|c}{ Coefficients } & $\begin{array}{c}\text { Standard } \\
\text { Err. }\end{array}$ & t Stat & P-value & Lower 95\% & Upper 95\% & $\begin{array}{r}\text { Lower } \\
95.0 \%\end{array}$ & $\begin{array}{l}\text { Upper } \\
95.0 \%\end{array}$ \\
\hline Intercept & 11.03254 & 13.229531 & 0.83393 & 0.40786 & -15.469396 & 37.534474 & -15.46940 & 37.53447 \\
X Variable 1 & 14.46313 & 4.766983 & 3.03402 & 0.00365 & 4.913718 & 24.012547 & 4.91372 & 24.01255 \\
\hline
\end{tabular}


E. Phosphate Sorption Index versus Log Extracted Magnetite Iron

\begin{tabular}{|l|r|}
\hline \multicolumn{2}{|l|}{$\begin{array}{l}\text { Regression } \\
\text { Statistics }\end{array}$} \\
\hline Multiple R & 0.055496 \\
R Square & 0.003080 \\
Adjusted R Square & -0.014722 \\
Standard Error & 37.689504 \\
Observations & 58 \\
\hline
\end{tabular}

\begin{tabular}{|r|rrrrr|}
\hline \multicolumn{1}{|l|}{ ANOVA } \\
\hline \multicolumn{1}{|c|}{$d f$} & & SS & MS & \multicolumn{1}{c|}{ S } & Sig. $F$ \\
\hline Regression & 1 & 245.75251 & 245.753 & 0.173004392 & 0.679045095 \\
Residual & 56 & 79547.927 & 1420.4987 & & \\
Total & 57 & 79793.679 & & & \\
\hline
\end{tabular}

\begin{tabular}{|c|c|c|c|c|c|c|c|c|}
\hline & \multicolumn{3}{|c|}{ Standard } & \multirow[b]{2}{*}{$P$-value } & \multirow[b]{2}{*}{ Lower 95\% } & \multirow[b]{2}{*}{ Upper 95\% } & \multirow{2}{*}{$\begin{array}{l}\text { Lower } \\
95.0 \% \\
\end{array}$} & \multirow{2}{*}{$\begin{array}{l}\text { Upper } \\
95.0 \%\end{array}$} \\
\hline & Coefficients & Err. & t Stat & & & & & \\
\hline Intercept & 45.46882 & 9.158576 & 4.96462 & 0.00001 & 27.121985 & 63.815650 & 27.12198 & 63.81565 \\
\hline X Variable 1 & 2.14791 & 5.164003 & 0.41594 & 0.67905 & -8.196837 & 12.492647 & -8.19684 & 12.49265 \\
\hline
\end{tabular}




\section{F. Log Extracted Exchangeable Iron versus $\mathrm{pH}$}

\begin{tabular}{|l|r|}
\hline \multicolumn{2}{|l|}{$\begin{array}{l}\text { Regression } \\
\text { Statistics }\end{array}$} \\
\hline Multiple R & 0.212025 \\
R Square & 0.044955 \\
Adjusted R & \\
Square & 0.027900 \\
Standard Error & 1.233899 \\
Observations & 58 \\
\hline
\end{tabular}

\begin{tabular}{|r|rrrrr|}
\hline \multicolumn{1}{|l|}{ ANOVA } & \multicolumn{1}{|c|}{ SS } & \multicolumn{1}{c|}{ MS } & \multicolumn{1}{c|}{$F$} & Sig. $F$ \\
\hline Regression & 1 & 4.0132576 & 4.013 & 2.63595541 & 0.11008564 \\
Residual & 56 & 85.260329 & 1.5225 & & \\
Total & 57 & 89.273586 & & & \\
\hline
\end{tabular}

\begin{tabular}{|c|c|c|c|c|c|c|c|c|}
\hline & \multicolumn{3}{|c|}{ Standard } & \multirow[b]{2}{*}{ P-value } & \multirow[b]{2}{*}{ Lower 95\% } & \multirow[b]{2}{*}{ Upper 95\% } & \multirow{2}{*}{$\begin{array}{l}\text { Lower } \\
95.0 \%\end{array}$} & \multirow{2}{*}{$\begin{array}{l}\text { Upper } \\
95.0 \%\end{array}$} \\
\hline & Coefficients & Err. & $t$ Stat & & & & & \\
\hline Intercept & 3.07243 & 0.756067 & 4.06370 & 0.00015 & 1.557846 & 4.587014 & 1.55785 & 4.58701 \\
\hline X Variable 1 & -0.26191 & 0.161318 & -1.62356 & 0.11009 & -0.585069 & 0.061249 & -0.58507 & 0.06125 \\
\hline
\end{tabular}




\section{G. Log Extracted Organic Bound Iron versus $\mathrm{pH}$}

\begin{tabular}{|l|r|}
\hline \multicolumn{2}{|l|}{$\begin{array}{l}\text { Regression } \\
\text { Statistics }\end{array}$} \\
\hline Multiple R & 0.454551 \\
R Square & 0.206617 \\
Adjusted R & \\
Square & 0.192449 \\
Standard Error & 0.913203 \\
Observations & 58 \\
\hline
\end{tabular}

\begin{tabular}{|r|rrrrr|}
\hline \multicolumn{1}{|l|}{ ANOVA } & \multicolumn{1}{|c|}{ df } & \multicolumn{1}{c|}{ SS } & MS & \multicolumn{1}{c|}{ F } & Sig. F \\
\hline Regression & 1 & 12.162 & 12.162 & 14.5837828 & 0.000337812 \\
Residual & 56 & 46.7007 & 0.8339 & & \\
Total & 57 & 58.8627 & & & \\
\hline
\end{tabular}

\begin{tabular}{|c|c|c|c|c|c|c|c|c|}
\hline \multicolumn{6}{|c|}{ Standard } & \multicolumn{3}{|c|}{ Lower } \\
\hline & Coefficients & Err. & t Stat & $P$-value & Lower 95\% & Upper 95\% & $95.0 \%$ & Upper $95.0 \%$ \\
\hline Intercept & 1.12083 & 0.559562 & 2.00305 & 0.05002 & -0.000108 & 2.241767 & -0.00011 & 2.24177 \\
\hline X Variable 1 & 0.45594 & 0.119391 & 3.81887 & 0.00034 & 0.216770 & 0.695107 & 0.21677 & 0.69511 \\
\hline
\end{tabular}




\section{H. Log Extracted Poorly Crystalline Iron versus pH}

\begin{tabular}{|l|r|}
\hline \multicolumn{2}{|l|}{ Regression Statistics } \\
\hline Multiple R & 0.684012 \\
R Square & 0.467873 \\
Adjusted R Square & 0.458370 \\
Standard Error & 0.621326 \\
Observations & 58 \\
\hline
\end{tabular}

\begin{tabular}{|c|c|c|c|c|c|}
\hline \multicolumn{6}{|l|}{ ANOVA } \\
\hline & $d f$ & SS & MS & $F$ & Sig. $F$ \\
\hline Regression & 1 & 19.00812 & 19.008 & 49.2379812 & 3.24437E-09 \\
\hline Residual & 56 & 21.61857 & 0.3860 & & \\
\hline Total & 57 & 40.62669 & & & \\
\hline
\end{tabular}

\begin{tabular}{|c|c|c|c|c|c|c|c|c|}
\hline & Coefficients & $\begin{array}{c}\text { Standard } \\
\text { Err. }\end{array}$ & $t$ Stat & P-value & Lower 95\% & Upper 95\% & Lower $95.0 \%$ & Upper $95.0 \%$ \\
\hline Intercept & 0.49050 & \#\#\#\#\#\#\# & 1.28836 & 0.20292 & -0.272165 & 1.253163 & -0.27217 & 1.25316 \\
\hline X Variable 1 & 0.57000 & \#\#\#\#\#\# & 7.01698 & 0.00000 & 0.407272 & 0.732724 & 0.40727 & 0.73272 \\
\hline
\end{tabular}




\section{Log Extracted Crystalline Iron versus $\mathrm{pH}$}

\begin{tabular}{|l|r|}
\hline $\begin{array}{l}\text { Regression } \\
\text { Statistics }\end{array}$ & 0.590241 \\
\hline Multiple R & 0.348384 \\
R Square & 0.336748 \\
Adjusted R Square & 0.791591 \\
Standard Error & 58 \\
Observations & \\
\hline
\end{tabular}

\begin{tabular}{|c|c|c|c|c|c|c|c|c|}
\hline & \multicolumn{6}{|l|}{ ANOVA } & & \\
\hline & \multicolumn{2}{|r|}{$d f$} & SS & MS & $F$ & Sig. $F$ & & \\
\hline & Regression & 1 & 18.761044 & 18.761 & 29.94022649 & $1.08 \mathrm{E}-06$ & & \\
\hline & Residual & 56 & 35.090532 & 0.6266 & & & & \\
\hline & Total & 57 & 53.851576 & & & & & \\
\hline & & Standard & & & & Upper & Lower & \\
\hline & Coefficients & Err. & $t$ Stat & $P$-value & Lower 95\% & $95 \%$ & $95.0 \%$ & Upper $95.0 \%$ \\
\hline Intercept & 0.01020 & 0.485045 & 0.02102 & 0.98330 & -0.961464 & 0.981858 & -0.96146 & 0.98186 \\
\hline $\mathrm{X}$ Variable 1 & 0.56628 & 0.103491 & 5.47177 & 0.00000 & 0.358963 & 0.773600 & 0.35896 & 0.77360 \\
\hline
\end{tabular}




\section{J. Log Extracted Magnetite versus $\mathrm{pH}$}

\begin{tabular}{|l|r|}
\hline \multicolumn{2}{|l|}{$\begin{array}{l}\text { Regression } \\
\text { Statistics }\end{array}$} \\
\hline Multiple R & 0.285782 \\
R Square & 0.081671 \\
Adjusted R Square & 0.065273 \\
Standard Error & 0.934628 \\
Observations & 58 \\
\hline
\end{tabular}

\begin{tabular}{|r|rrrrr|}
\hline \multicolumn{1}{|l|}{ ANOVA } & \multicolumn{1}{|c|}{ SS } & MS & \multicolumn{1}{c|}{ S } & Sig. $F$ \\
\hline Regression & 1 & 4.3504797 & 4.350 & 4.980342402 & 0.029656628 \\
Residual & 56 & 48.917693 & 0.8735 & & \\
Total & 57 & 53.268173 & & & \\
\hline
\end{tabular}

\begin{tabular}{|c|c|c|c|c|c|c|c|c|}
\hline & \multicolumn{3}{|c|}{ Standard } & \multirow[b]{2}{*}{ P-value } & \multirow[b]{2}{*}{ Lower 95\% } & \multirow[b]{2}{*}{ Upper 95\% } & \multirow[b]{2}{*}{ Lower $95.0 \%$} & \multirow[b]{2}{*}{ Upper $95.0 \%$} \\
\hline & Coefficients & Err. & t Stat & & & & & \\
\hline Intercept & 0.24396 & \#\#\#\#\#\#\#\# & 0.42599 & 0.67175 & -0.903276 & 1.391196 & -0.90328 & 1.39120 \\
\hline X Variable 1 & 0.27269 & \#\#\#\#\#\#\#\# & 2.23167 & 0.02966 & 0.027912 & 0.517472 & 0.02791 & 0.51747 \\
\hline
\end{tabular}


K. Phosphate Sorption Index versus $\mathrm{pH}$

\begin{tabular}{|l|r|}
\hline \multicolumn{2}{|l|}{ Regression Statistics } \\
\hline Multiple R & 0.481117 \\
R Square & 0.231473 \\
Adjusted R Square & 0.217750 \\
Standard Error & 33.091750 \\
Observations & 58 \\
\hline
\end{tabular}

\begin{tabular}{|r|rcccc|}
\hline \multicolumn{1}{|l|}{ ANOVA } \\
\hline \multicolumn{1}{|r|}{ df } & & SS & MS & F & Sig. $F$ \\
\hline Regression & 1 & 18470.101 & 18470.101 & 16.86668786 & 0.000131825 \\
Residual & 56 & 61323.578 & 1095.0639 & & \\
Total & 57 & 79793.679 & & & \\
\hline
\end{tabular}

\begin{tabular}{|c|c|c|c|c|c|c|c|c|}
\hline & Coefficients & $\begin{array}{c}\text { Standard } \\
\text { Err. }\end{array}$ & t Stat & $P$-value & Lower 95\% & Upper 95\% & Lower $95.0 \%$ & Upper $95.0 \%$ \\
\hline Intercept & -32.66645 & 20.276849 & -1.61102 & 0.11280 & -73.285858 & 7.952963 & -73.28586 & 7.95296 \\
\hline X Variable 1 & 17.76799 & 4.326368 & 4.10691 & 0.00013 & 9.101235 & 26.434747 & 9.10124 & 26.43475 \\
\hline
\end{tabular}


L. Phosphate Sorption Index versus Log Total Extracted Iron

\begin{tabular}{|l|r|}
\hline \multicolumn{2}{|l|}{ Regression Statistics } \\
\hline Multiple R & 0.650559 \\
R Square & 0.423227 \\
Adjusted R Square & 0.412928 \\
Standard Error & 28.667684 \\
Observations & 58 \\
\hline
\end{tabular}

\begin{tabular}{|r|rrrrr|}
\hline \multicolumn{2}{|l|}{ ANOVA } \\
\hline \multicolumn{1}{|l|}{ df } & & SS & MS & F & Sig. $F$ \\
\hline Regression & 1 & 33770.858 & 33770.858 & 41.09196321 & $3.24392 \mathrm{E}-08$ \\
Residual & 56 & 46022.821 & 821.8361 & & \\
Total & 57 & 79793.679 & & & \\
\hline
\end{tabular}

\begin{tabular}{|c|c|c|c|c|c|c|c|c|}
\hline & Coefficients & $\begin{array}{c}\text { Standard } \\
\text { Err. }\end{array}$ & t Stat & P-value & Lower 95\% & Upper 95\% & Lower $95.0 \%$ & Upper $95.0 \%$ \\
\hline Intercept & -136.49335 & 29.130169 & -4.68564 & 0.00002 & -194.848092 & -78.138610 & -194.84809 & -78.13861 \\
\hline X Variable 1 & 44.12272 & 6.883096 & 6.41030 & 0.00000 & 30.334219 & 57.911214 & 30.33422 & 57.91121 \\
\hline
\end{tabular}


